OPEN ACCESS

Edited by: Sarah Kelly McMenamin, Boston College, United States

Reviewed by:

Juan Ignacio Fernandino, CONICET Institute of Biotechnological Research (IIB-INTECH), Argentina Ivan Manzini,

University of Giessen, Germany

${ }^{*}$ Correspondence: Laurent M. Sachs sachs@mnhn.fr

Specialty section:

This article was submitted to Evolutionary Developmental Biology, a section of the journa Frontiers in Ecology and Evolution

Received: 02 July 2021 Accepted: 13 September 2021 Published: 04 October 2021

Citation:

Rousseau K, Dufour S and Sachs LM (2021) Interdependence

of Thyroid and Corticosteroid Signaling in Vertebrate Developmental

Transitions.

Front. Ecol. Evol. 9:735487. doi: 10.3389/fevo.2021.735487

\section{Interdependence of Thyroid and Corticosteroid Signaling in Vertebrate Developmental Transitions}

\author{
Karine Rousseau ${ }^{1}$, Sylvie Dufour ${ }^{1}$ and Laurent M. Sachs ${ }^{2 *}$ \\ 1 UMR BOREA, CNRS, Muséum National d'Histoire Naturelle, Sorbonne Université, Paris, France, ${ }^{2}$ UMR PhyMA, CNRS, \\ Muséum National d'Histoire Naturelle, Paris, France
}

Post-embryonic acute developmental processes mainly allow the transition from one life stage in a specific ecological niche to the next life stage in a different ecological niche. Metamorphosis, an emblematic type of these post-embryonic developmental processes, has occurred repeatedly and independently in various phylogenetic groups throughout metazoan evolution, such as in cnidarian, insects, molluscs, tunicates, or vertebrates. This review will focus on metamorphoses and developmental transitions in vertebrates, including typical larval metamorphosis in anuran amphibians, larval and secondary metamorphoses in teleost fishes, egg hatching in sauropsids and birth in mammals. Two neuroendocrine axes, the hypothalamic-pituitary-thyroid and the hypothalamic-pituitary-adrenal/interrenal axes, are central players in the regulation of these life transitions. The review will address the molecular and functional evolution of these axes and their interactions. Mechanisms of integration of internal and environmental cues, and activation of these neuroendocrine axes represent key questions in an "eco-evo-devo" perspective of metamorphosis. The roles played by developmental transitions in the innovation, adaptation, and plasticity of life cycles throughout vertebrates will be discussed. In the current context of global climate change and habitat destruction, the review will also address the impact of environmental factors, such as global warming and endocrine disruptors on hypothalamic-pituitary-thyroid and hypothalamic-pituitary-adrenal/interrenal axes, and regulation of developmental transitions.

Keywords: thyroid hormones, corticosteroids, hormonal crosstalk, metamorphosis, development, environment, stress

\section{INTRODUCTION}

The hypothalamic-pituitary-thyroid (HPT) axis is the neuroendocrine thyrotropic axis, which literally acts ("trope") on the thyroid gland ("thyro"). In a simplified way, it is composed of brain thyrotropin-releasing hormone (TRH) neurons, pituitary thyrotropin (TSH) cells, and peripheral thyroid hormones $(\mathrm{TH})$, thyroxine $\left(\mathrm{T}_{4}\right)$ and triiodothyronine $\left(\mathrm{T}_{3}\right)$. TRH acts via its receptor 
(TRH-R) expressed by the pituitary thyrotropes, and stimulates the synthesis and release of pituitary TSH. TSH binds its receptor (TSH-R) expressed by the thyroid gland to induce the production and release of $\mathrm{T}_{4}$. At target tissues, $\mathrm{T}_{4}$ is transformed into $\mathrm{T}_{3}$ by monodeiodinases, and both bind to $\mathrm{TH}$ nuclear receptor, TR. TH can act on various tissues and they negatively feedback on the brain (hypothalamic TRH)/pituitary (TSH) axis (Zoeller et al., 2007).

The hypothalamic-pituitary-adrenal axis (HPA), in mammals and sauropsids, and hypothalamic-pituitary-interrenal (HPI), in amphibians and teleosts, is the neuroendocrine corticotropic axis responsible for the response to stress in all vertebrates (Gorissen and Flik, 2016). The neurohormone, corticotropinreleasing hormone $(\mathrm{CRH})$, controls the production and release of corticotropin (also named adrenocorticotropic hormone, ACTH), at the pituitary level. ACTH acts to control the production and release of corticosteroids (CS) from adrenal cortex cells in amniotes or interrenal cells in amphibians and teleosts. CS can act on various tissues and they negatively feedback on the brain (hypothalamic $\mathrm{CRH}$ ) / pituitary (ACTH) corticotropic axis (Bernier et al., 2009; Faught et al., 2016; Gorissen and Flik, 2016) via specific receptors.

The molecular components of the HPT and HPA/HPI axes have been subject to whole genome duplication (WGD) events during evolution. Two events of WGD, referred to as $1 \mathrm{R}$ and $2 \mathrm{R}$ for first and second rounds of WGD, occurred in ancestral vertebrates (Dehal and Boore, 2005). An additional WGD event occurred in ancestral teleosts, referred to as $3 \mathrm{R}$ for third round of WGD or as teleost specific WGD (Meyer and Schartl, 1999). A further WGD occurred more recently in some teleost groups, such as salmonids (Lien et al., 2016) and some carps (Wang et al., 2012). This event is referred to as $4 \mathrm{R}$ (fourth round of WGD). The WGD were at the origin of the diversification of the functions of the HPT and HPA/HPI axis.

One of the actions controlled by the HPT and HPA/HPI axis in vertebrates is the developmental body change coming from a need to adapt to a remarkable change in habitat during birth, hatching or post-embryonic development events. Dramatic changes occur in various metazoa such as cnidaria, insects, crustacean, molluscs, tunicates, and vertebrates. These events have been collectively termed as metamorphosis from the Greek meta- (change) and morph (form). Metamorphosis has a major role in the structure of complex life cycles encompassing different ecophases. In vertebrates, different developmental modes are observed. Amniotes, namely mammals, and sauropsids (birds and reptiles), as well as some amphibians, go through direct development and present a more mature stage at birth/hatching, with an earlier ontogeny of the HPA axis. Non-amniotes, comprising various fish and amphibians, go through indirect development with metamorphosis and present a more immature stage at hatching with a later ontogeny of the HPT and HPA/HPI axis. All the post-embryonic developmental changes are hormonally controlled processes by TH (Paris and Laudet, 2008), but recent studies confer to CS an increasingly prominent role (Sachs and Buchholz, 2017). These TH and CS actions allow to distinguish this period from other major late developmental events such as puberty, which is under the control of sexual steroids.

The post-embryonic developmental transitions are also sensitive to diverse biotic and abiotic factors that can profoundly influence behavior, morphology, growth, development, and sometimes survival. Vertebrates respond to the exposome by modulating the production of $\mathrm{CS}$ and $\mathrm{TH}$ (Figure 1). The adaptive response allows to adjust the timing of the developmental program, but with a trade-off between risk and benefit.

\section{MOLECULAR AND FUNCTIONAL EVOLUTION OF THE HYPOTHALAMIC-PITUITARY-THYROID AND THE HYPOTHALAMIC-PITUITARY- ADRENAL/INTERRENAL AXES AND THEIR INTERACTIONS}

\section{Hypothalamic-Pituitary-Thyroid Axis Thyrotropin-Releasing Hormone and Its Receptors}

The hypothalamic-pituitary-thyroid (HPT) axis is the neuroendocrine thyrotropic axis (Figure 2). After indirect evidence of the existence of a thyrotropin-releasing factor in dogs (Shibusawa et al., 1955), a fraction, purified from bovine or ovine hypothalamic extracts, was found to stimulate the release of TSH (Schreiber et al., 1961; Guillemin et al., 1962, 1963). The TRH gene encodes multiple identical repeats of the three amino-acid (pyroglutamic acid-histidine-proline) TRH sequence (Galas et al., 2009). This is an example of intragenic duplication which allows an amplification of the synthesis and production of this neurohormone.

TRH-R are members of membrane class A G-protein coupled receptors (GPCR). Two subtypes, TRH-R1 and TRH-R2, have been characterized in mammals. A third one, TRH-R3, has been identified in birds ( $\mathrm{Li}$ et al., 2020), amphibians (Bidaud et al., 2002), reptiles (Li et al., 2020), and teleosts (Mekuchi et al., 2011; Saito et al., 2011; Li et al., 2020). In birds, only TRHR1 and TRH-R3 have been identified so far (Li et al., 2020). Four subtypes have been cloned in sockeye salmon Oncorhynchus nerka (TRH-R1, TRH-R2a, TRH-R2b, and TRH-R3; Saito et al., 2011), and in medaka Oryzias latipes (TRH-R1a, TRH-R1b, TRH-R2, and TRH-R3; Mekuchi et al., 2011). As in medaka (Mekuchi et al., 2011), duplicated TRH-R1a and b are found in many teleosts including zebrafish Danio rerio, and might be the result of $3 \mathrm{R}$, even if only one TRH-R1 is identified in sockeye salmon (Saito et al., 2011). The duplicated TRH$\mathrm{R} 2 \mathrm{~s}$ present in sockeye salmon may be due to the $4 \mathrm{R}$; TRH$\mathrm{R} 2 \mathrm{~b}$ is truncated (Saito et al., 2011). According to the recent hypothesis of Li et al. (2020) on the evolutionary history of TRH-Rs, multiple gene loss events might have occurred during evolution, including TRH-R2 loss in birds, and many mammals, as well as TRH-R3 loss in mammals. Interestingly, pituitary TRHR3 expression was recently shown to elevate as metamorphosis progressed in bullfrog tadpole (Nakano et al., 2018). It would be interesting to investigate whether the possible involvement of 


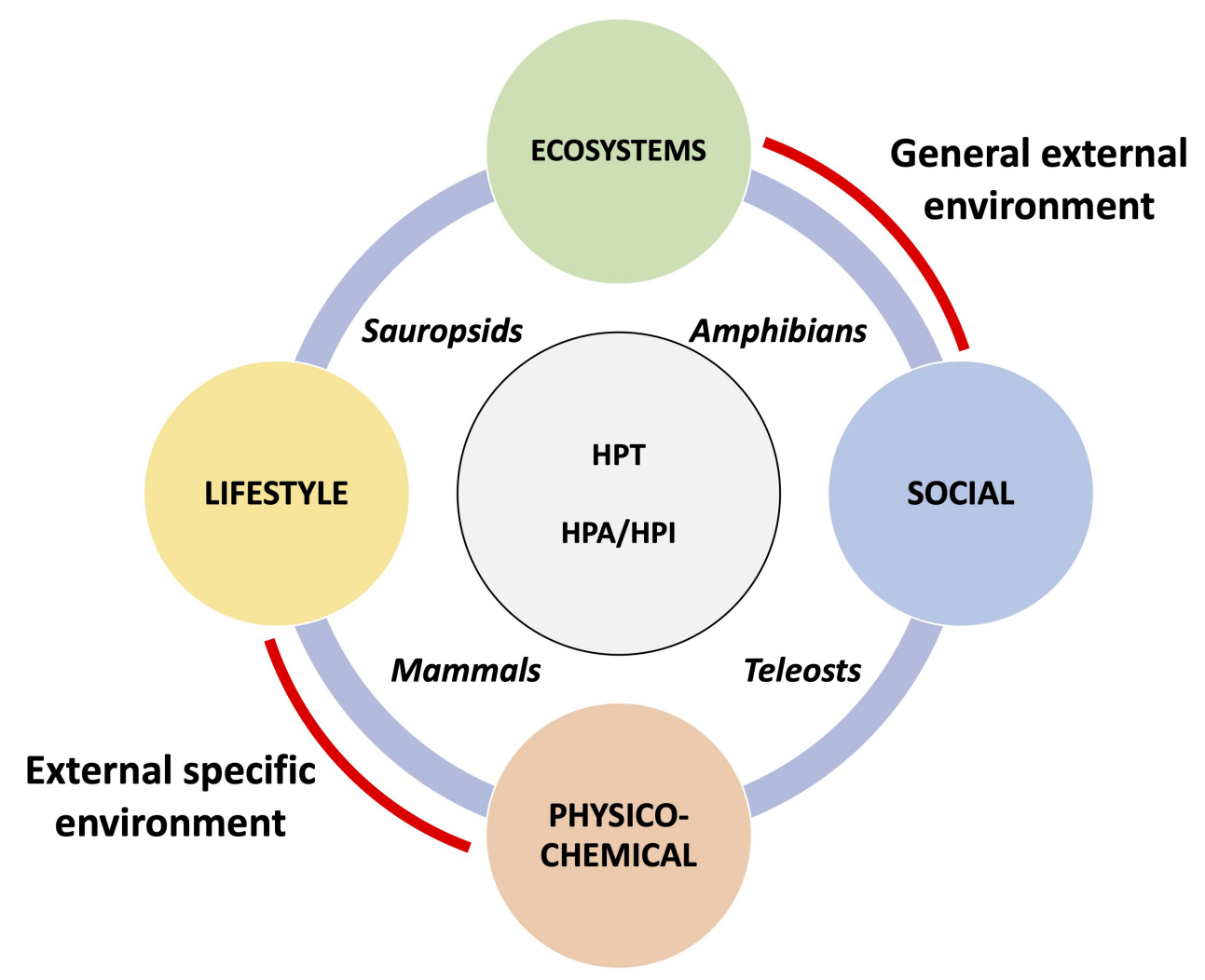

FIGURE 1 | The exposome targets the HPT and HPA/HPI axe in vertebrates. The four components of the exposome (ecosystems, lifestyle, social, and physico-chemical expositions) may affect developmental transitions in vertebrates, including teleosts, amphibians, sauropsids, and mammals, by acting in part at the level of the HPT and HPA/HPI axes.

TRH-R3 in amphibian metamorphosis is also observed in other major life history transitions, such as teleost metamorphoses and sauropsid hatching.

\section{Thyrotropin and Its Receptors}

TSH is a glycoprotein hormone composed of two subunits, the alpha subunit $(\mathrm{Gp} \alpha)$ common to gonadotropins, and the hormone-specific TSH $\beta$ subunit, which is paralogous to the luteinising hormone (LH) and follicle-stimulating hormone (FSH) $\beta$ subunits. The genes encoding the $\beta$ subunits of the two gonadotropins $\mathrm{LH}, \mathrm{FSH}$ and of TSH are paralogous genes that likely arose from the two successive $1 \mathrm{R} / 2 \mathrm{R}$ in ancestral vertebrates. A single TSH $\beta$ is present in mammals and other tetrapods, as well as in actinopterygians, and is considered as the "classical" TSH. Its $\beta$ subunit is now named TSH $\beta 1$ since a second TSH $\beta$, called TSH $\beta 2$, has been identified in some representative species of early vertebrates such as in chondrichthyans and basal sarcopterygians (Maugars et al., 2014). These data suggest that the gene coding for $t \operatorname{sh} \beta 2$ was lost twice independently during osteichthyan evolution, in a tetrapod ancestor and in an actinopterygian ancestor. Indeed $t \operatorname{sh} \beta 2$ could not be retrieved in the genome of an holostean (spotted gar Lepisosteus oculatus) nor any teleosts, supporting an early loss of $t \operatorname{sh} \beta 2$ in the actinopterygian lineage, leading to inheritance of only $\operatorname{tsh} \beta 1$ by the teleost lineage (Maugars et al., 2014). Two tsh $\beta$ paralogs were found in teleosts, resulting from the $3 \mathrm{R}$ duplication of $t \operatorname{sh} \beta 1$ (Maugars et al., 2014; Fleming et al., 2019), and named $t \operatorname{sh} \beta 1 a$ and $t \operatorname{sh} \beta 1 b$ (Fleming et al., 2019). Recently, up to three $t \operatorname{sh} \beta 1$ paralogs were identified in Oncorhynchus species, due to the conservation of the duplicated 4R-paralogs of $t \operatorname{sh} \beta 1 a(t \operatorname{sh} \beta 1 a \alpha$ and $t \operatorname{sh} \beta 1 a \beta$ ) while only the two $t \operatorname{sh} \beta 1$ paralogs issued from $3 \mathrm{R}$ $(t \operatorname{sh} \beta 1 a$ and $t \operatorname{sh} \beta 1 b)$ are present in Atlantic salmon Salmo salar as in other teleosts (Fleming et al., 2019). Interestingly, the two tsh $\beta$ paralogs identified in Atlantic salmon are expressed in different pituitary cells (Fleming et al., 2019): tsh $\beta 1 a$ in the anterior adenohypophysis, and $t s h \beta 1 b$ in cells near to the pituitary stalk, cells comparable to the pars tuberalis TSH cells involved in seasonal physiology and behavior in birds (Yoshimura, 2013) and mammals (Dardente et al., 2019).

TSH-R is present at the surface of the thyroid follicle cells in the thyroid gland. It belongs to the class A GPCR receptors and is paralogous to the receptors for gonadotropins. In teleosts, due to the $3 \mathrm{R}$, duplicated receptors tshra and tshrb have been characterized (Maugars et al., 2014). TSH-R are not only expressed in the thyroid gland, but also in a variety of other tissues (Williams, 2011). Of particular interest is the presence of tshr in the brain and the gonads, where they mediate TSH retrograde action on brain deiodinase and direct regulatory effect on reproduction, in birds and mammals (Nakane and Yoshimura, 2019). 


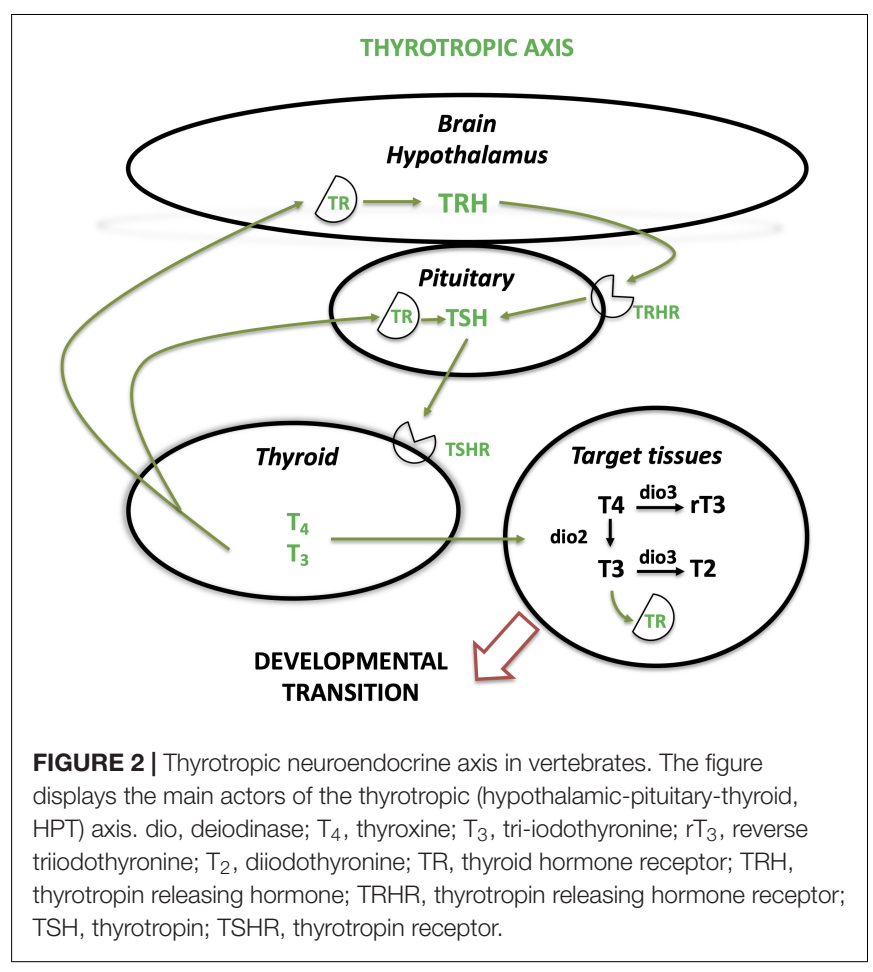

\section{Thyroid Hormones and Their Receptors}

Two main forms of $\mathrm{TH}$ are found in vertebrates, $\mathrm{T}_{4}$ with four iodinated tyrosine residues $\left(3,3^{\prime}, 5,5^{\prime}\right)$, the hormonal precursor produced by the thyroid gland, and $\mathrm{T}_{3}$ with three iodinated tyrosine residues $\left(3,3^{\prime}, 5\right)$, the active hormone which binds to TR with a 10-fold higher affinity compared to $\mathrm{T}_{4}$ (Holzer et al., 2017). $\mathrm{T}_{4}$ is produced, by thyrocytes under TSH control, from thyroglobulin, a large dimeric protein containing many tyrosine residues.

TR belong to the nuclear receptor superfamily. Two homologous receptors, TR $\alpha$ and TR $\beta$, are present in tetrapods (Sap et al., 1986; Weinberger et al., 1986; Thompson et al., 1987; Brooks et al., 1989; Helbing et al., 2006; Kanaho et al., 2006). The $3 \mathrm{R}$ led to two duplicated tra paralogs and two duplicated $\operatorname{tr} \beta$ paralogs in basal teleosts, such as conger and eel. So far, four $\operatorname{tr}$ cDNAs have been cloned in Japanese flounder: two $\alpha$ types and two $\beta$ types (Yamano et al., 1994; Yamano and Inui, 1995). In some other teleosts, such as zebrafish, two tr $\alpha$ genes but a single $\operatorname{tr} \beta$ gene have been retrieved, suggesting that one of the $\operatorname{tr} \beta$ duplicated paralog would have been lost in the course of teleost evolution (Lazcano and Orozco, 2018). Xenopus laevis possesses two distinctive genes for each $\operatorname{tr}$ likely due to its genome polyploidisation (Yaoita et al., 1990). In tetrapods, alternative splicing of TR leads to various protein isoforms with different binding activities and biological functions. In mammals, two TR $\alpha$ variants $(\alpha 1$ and $\alpha 2)$ are thus generated from a single gene (Izumo and Mahdavi, 1988). Similarly, in addition to the 3R-duplicated genes, alternative splicing may lead to a large variety of TR isoforms in teleosts, with species-specific variations (Marchand et al., 2001).

\section{Deiodinases}

Deiodination of TH corresponds to the removal of iodine from their outer or inner rings, and is performed by iodothyronine deiodinase enzymes in the thyroid, peripheral or central target tissues. By regulating the bioavailability of $\mathrm{T}_{4}$ and $\mathrm{T}_{3}$, they thus control their action (Bianco et al., 2002; Orozco and Valverde-R, 2005; Darras and Van Herck, 2012; Orozco et al., 2012; Steegborn and Schweizer, 2020). The first deiodinase to be cloned was dio1 from rat (Berry et al., 1991), then dio3 was cloned from Xenopus laevis (St. Germain et al., 1994), and dio2 from Rana catesbeiana (Davey et al., 1995). So far, these three types of iodothyronine deiodinases, DIO1, DIO2, and DIO3, have been identified in most vertebrates (Bianco et al., 2002; Darras and Van Herck, 2012; Orozco et al., 2012). DIO1 is a low selectivity enzyme with both outer and inner ring deiodinase activity. DIO2 is an outer ring deiodinase, which removes an iodine residue from $\mathrm{T}_{4}$ and gives active $\mathrm{T}_{3}$. DIO3 is an inner ring deiodinase, which inactivates $\mathrm{T}_{4}$ and $\mathrm{T}_{3}$ in reverse $\mathrm{T}_{3}\left(\mathrm{rT}_{3}\right.$ or $\left.3,3^{\prime}, 5^{\prime}-\mathrm{T}_{3}\right)$, and diiodothyronine $\left(\mathrm{T}_{2}\right.$ or $\left.3,3^{\prime}-\mathrm{T}_{2}\right)$, respectively. Orozco et al. (2012) reviewed the evolutionary history of deiodinase family and point out that dio1 is the oldest vertebrate deiodinase gene and dio2 the most recent one. Some teleosts possess 3R-duplicated dio2 and dio3 genes (Orozco et al., 2012; Alves et al., 2017). The widespread and differential tissue distribution for the three types of deiodinase in vertebrates has been reviewed previously (Darras and Van Herck, 2012; Orozco et al., 2012). In the Atlantic salmon, up to six deiodinase paralogs have been characterized, one dio1, two dio2 (dio2a and dio2b) and three dio3 (dio3a1, dio3a2, and dio3b) (Lorgen et al., 2015). A single dio2 gene is present in Northern pike Esox lucius (Rondeau et al., 2014), which suggests that the two dio2 paralogs of the Atlantic salmon arose recently from the salmonid-specific WGD, 4R (Lorgen et al., 2015). Dio3a1/3a2 likely also resulted from 4R (Lorgen et al., 2015). Functional divergence of the two salmon dio2 paralogs is reported: while gill dio2a expression is induced by seawater exposure (Lorgen et al., 2015), dio2b expression in the brain is sensitive to photoperiod during smoltification (Lorgen et al., 2015; Irachi et al., 2021).

\section{Hypothalamic-Pituitary- Adrenal/Interrenal}

\section{Corticotropin-Releasing Hormone and Its Receptors}

The hypothalamic-pituitary-adrenal axis (HPA), in mammals and sauropsids, and hypothalamic-pituitary-interrenal (HPI), in amphibians and teleosts, is the neuroendocrine corticotropic axis (Figure 3). In 1955, a substance, present in extracts of mammalian hypothalamus and able to stimulate ACTH secretion in vitro, was named corticotropin-releasing factor (CRF) (Guillemin and Rosenberg, 1955; Saffran et al., 1955). CRF (or CRH) was first isolated from sheep hypothalamus (Vale et al., 1981) and identified in all vertebrates thereafter (Lovejoy et al., 2014; On et al., 2019). Together with urotensin I (UI) in teleosts, sauvagine (SVG) in amphibians, and urocortins (Ucn) in mammals, it forms a large family of peptides, the $\mathrm{CRH}$ /urocortin family. As $\mathrm{CRH}$, urotensin I, sauvagine and urocortins have roles in the regulation of ACTH and $\mathrm{MSH}$, as well as energy metabolism and reproduction (Lovejoy and Balment, 1999). It 


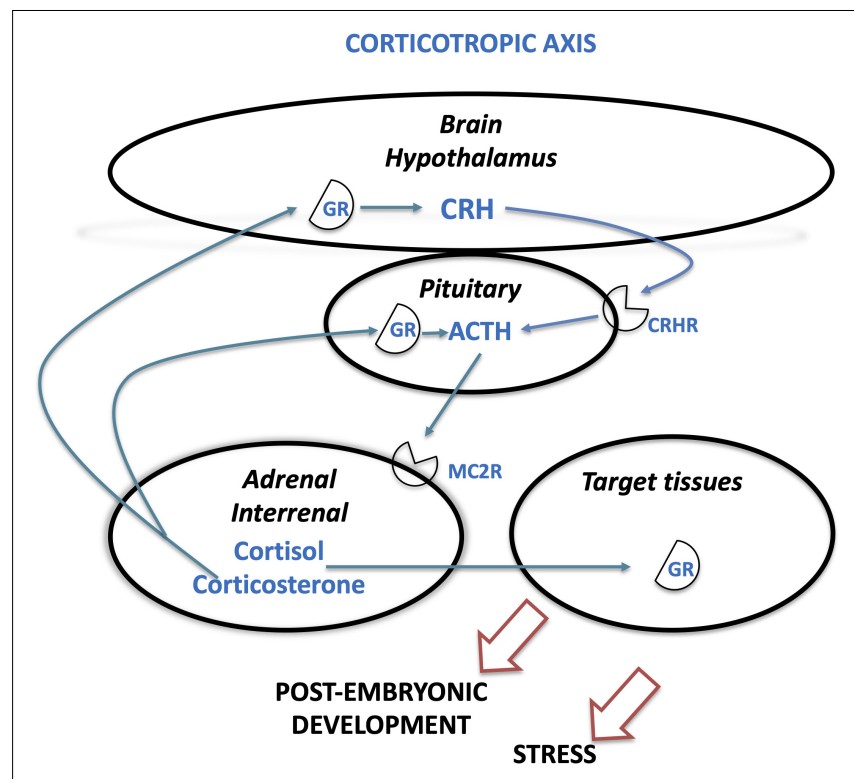

FIGURE 3 | Corticotropic neuroendocrine axis in vertebrates. The figure displays the main actors of the corticotropic

(hypothalamic-pituitary-adrenal/interrenal, HPA/HPI) axis. ACTH, adrenocorticotropin; $\mathrm{CRH}$, corticotropin-releasing hormone; $\mathrm{CRHR}$, corticotropin-releasing hormone receptor; GR, glucocorticoid receptor; MC2R, melanocortin receptor 2.

was first suggested that two ancestral $c r h / u c n 1$ and $u c n 2 / u c n 3$ genes likely arose by specific gene duplication before vertebrate WGD events (Hwang et al., 2013), as a single crh-like gene is identified in amphioxus and tunicates (On et al., 2019). Both ancestral genes were duplicated twice in ancestral vertebrates via $1 \mathrm{R}$ and $2 \mathrm{R}$, followed by some paralog losses, leading to up to 5 genes (crh1, crh2, ucn1 coming from ancestral $c r h / u c n 1 ; u c n 2, u c n 3$ issued from ancestral ucn2/ucn3) in extant representative species of some vertebrate lineages such as chondrichthyans, holosteans and actinistians (Cardoso et al., 2016; On et al., 2019). Teleost specific 3R resulted in the duplication of crh1 into two paralogs crh1a and $c r h 1 b$ conserved in many species (Grone and Maruska, 2015; Cardoso et al., 2016). Crh2 may have been lost in recent teleosts (Cardoso et al., 2016), while one 3R-crh2 paralog has been conserved in basal groups of teleosts such as European eel (Maugars et al., 2016).

In tetrapods, $\mathrm{CRH}$ has been shown to act via two GPCRs, corticotropin-releasing hormone receptors (CRHR), CRHR1, and CRHR2, which belong to the class 2 subfamily B1 of secretin-like GPCR superfamily (Lovejoy et al., 2014). Crhr1 was duplicated by $3 \mathrm{R}$ into two paralogs (crhrla and crhrlb) which were conserved in many extant teleosts, while one of 3R-duplicated crhr2 paralogs would have been lost (Cardoso et al., 2016). A third CRHR, CRHR3, identified in the catfish, Ameiurus nebulosus (Arai et al., 2001), highly similar to catfish CRHR1, likely results from gene-specific duplication, that may also occurred in various teleosts (Lovejoy et al., 2014; Cardoso et al., 2016).

\section{Proopiomelanocortin-Derived Peptides and Their Receptors}

The main pituitary hormone involved in the HPA/HPI axis is ACTH. ACTH is derived from tissue-specific post-translational processing of its precursor, the proopiomelanocortin (POMC); POMC also gives rise to melanocyte stimulating hormone $(\mathrm{MSH})$, and $\beta$-endorphin ( $\beta$-END). POMC forms the opioid/orphanin gene family together with proenkephalin, prodynorphin and proorphanin (Dores et al., 2002; Sundström et al., 2010). ACTH and MSH, called melanocortins (MC), act via MC receptors (MCR), while $\beta$-END acts via opioid receptor. Teleost $3 \mathrm{R}$ gave rise to pomc gene duplicates: pomc$\alpha(a$ or $A)$ and pomc- $\beta$ ( $b$ or $B)$, with pomc- $\beta$ having lost a functional $\beta$-endorphin (De Souza et al., 2005). Further independent gene-specific duplications during teleost evolution resulted in duplicates of pomc- $\alpha$, such as in sea bream Sparus aurata (Cardoso et al., 2011) and Astatotilapia burtoni (Harris et al., 2014).

Melanocortin receptors (MCR) belong to the rhodopsin class A13 family of GPCRs. In tetrapods, five MCR genes have been identified: $m c 1 r$ to $m c 5 r$ (Cortés et al., 2014; Dores et al., 2014). In teleost fish, probably due to $3 \mathrm{R}$, the number of receptors increases up to six in zebrafish, which has two MC5R paralogs (Västermark and Schiöth, 2011), while pufferfish Fugu rubripes has only four, with no $m c 3 r$ and only one copy of $m c 5 r$ (Logan et al., 2003). Concerning the ligand selectivity of MCRs, all of the paralogous MCRs can be activated by both ACTH and MSH in extant cartilaginous fishes, while in extant teleosts and tetrapods, only ACTH can activate MC2R (Cortés et al., 2014; Dores et al., 2014). In mammals, the MCRs have distinct tissue expression (Cone, 2006; Dores et al., 2014): $m c 1 r$ is mainly expressed in melanocytes; $m c 2 r$ in adrenal cortex; $m c 3 r$ and $m c 4 r$ in the brain; and $m c 5 r$ in a variety of exocrine glands, such as sebaceous, lacrimal and preputial glands. In concordance with their expression sites, each MCR has its proper function: MC1R is involved in skin and hair pigmentation; MC2R in adrenal steroidogenesis and stress response; MC3R and MC4R in energy homeostasis; and MC5R in exocrine gland secretion. These features can also be observed in non-mammalian vertebrates, with some differences. Of particular interest, $m c 5 r$ is co-expressed with $m c 2 r$ in the interrenal of Xenopus tropicalis (Dores and Garcia, 2015) and several teleosts [rainbow trout Oncorhynchus mykiss (Haitina et al., 2004; Aluru and Vijayan, 2008); common carp Cyprinus carpio (Metz et al., 2005); barfin flounder Verasper moseri (Kobayashi et al., 2011)], as well as in the chicken adrenal (Takeuchi and Takahashi, 1998), suggesting a possible role of MC5R, in addition to MC2R, in the regulation of HPI axis in these non-mammalian vertebrates.

\section{Corticosteroids and Their Receptors}

Corticosteroids (CS) are steroid hormones, divided into glucocorticoids (GC), and mineralocorticoids (MC). In mammals and sauropsids, CS are synthetized by the adrenal gland. In amphibians and teleosts, CS are synthetized by the interrenal gland, a tissue embedded inside the anterior part of the kidney (head kidney) and homologous to the adrenal cortex of the adrenal gland in mammals (Chester-Jones, 1987). Cortisol 
is the primary GC in most mammals and teleosts, while it is corticosterone in birds, reptiles, amphibians and many rodents (Mommsen et al., 1999; Aerts, 2018). Both GC can co-exist in most vertebrates. Aldosterone, which is the principal MC in mammals (Gilmour, 2005), is lacking in all teleosts studied so far. In teleosts, it is generally accepted that cortisol plays both GC and MC roles (McCormick, 2001; McCormick et al., 2008).

GC and MC receptors (respectively, GR and MR) belong to the nuclear receptor superfamily. $2 \mathrm{R}$ resulted in the emergence of GR and MR, present in all extant vertebrates. In teleosts, 3R gave rise to duplicated $g r$ and $m r$ (Bury, 2017). Zebrafish is the only known teleost to have conserved only one of the two gr paralogs (Schaaf et al., 2008). The two $m r$ paralogs are present in a basal teleost, the European eel Anguilla anguilla (Lafont et al., 2014), while only one $m r$ paralog has been conserved in the other extant teleosts studied so far (Baker and Katsu, 2019).

\section{METAMORPHOSES AND OTHER DEVELOPMENTAL TRANSITIONS IN VERTEBRATES AND THEIR CONTROL BY THYROID HORMONES AND CORTICOSTEROIDS}

\section{Larval Metamorphosis in Anuran Amphibians \\ Involvement of Thyroid Hormones}

After hatching and a period of growth, the tadpole undergoes a rapid and irreversible physiological, anatomical and environmental transition marking the transition from the larval state to the adult state, the metamorphosis. Gudernatch observed that the administration of extracts of the thyroid gland (and only this organ) via the water induced tadpole premature metamorphosis (Gudernatch, 1912). Following TH measurements (Leloup and Buscaglia, 1977), the elucidation of the roles and mechanisms of action of $\mathrm{TH}$ in vertebrates has thus benefited enormously from amphibian model (Grimaldi et al., 2013; Buchholz, 2017; Sachs and Buchholz, 2017). The activity of $\mathrm{TH}$ is regulated locally by deiodinases (DIO) and cytosolic proteins (Shi et al., 1994). In particular, the expression of DIO2 (enzyme activating $\mathrm{TH}$ ) is high in tissues undergoing metamorphosis, while the expression of inactivating deiodinase (DIO3) is high in tissues before and after metamorphosis (Leloup et al., 1981; Galton, 1989).

Another level of $\mathrm{TH}$ signaling control is linked to the expression profiles of thyroid hormone receptors (TR) (Yaoita and Brown, 1990). A dual role of thyroid signaling was proposed (Sachs et al., 2000; Grimaldi et al., 2013; Buchholz and Shi, 2018). Thus, before metamorphosis, the relative absence of $\mathrm{TH}$ and the expression of $\mathrm{TR} \alpha$ contribute to repressing target genes allowing tadpole growth. During the climax of metamorphosis, the high concentration of $\mathrm{TH}$ concomitant with the expression of $\operatorname{TR} \alpha$ and $\operatorname{TR} \beta$ contributes to the activation of the transcriptional program leading to tadpole transformation. The two TR isoforms have also different roles during metamorphosis. $\mathrm{TR} \alpha$ was shown to be more involved in cell proliferation while $\operatorname{TR} \beta$ in cell differentiation and apoptosis (Furlow and Neff, 2006; Denver et al., 2009). TR $\alpha$ is required for TH-dependent neurogenesis (Wen et al., 2019). The autoinduction of $\operatorname{TR} \beta$ is one of the earliest responses to the thyroid signal (Yaoita and Brown, 1990) because $\operatorname{tr} \beta$ is a direct TH-target gene (Ranjan et al., 1994; Bilesimo et al., 2011).

Transgenic studies in Xenopus laevis revealed that TR are necessary and sufficient for mediating the effects of $\mathrm{T}_{3}$ during metamorphosis (Buchholz et al., 2003, 2004). However, recent gene knockout studies in Xenopus tropicalis showed that TR are not required for most metamorphic transformations, although tadpoles lacking TR die in the middle of metamorphosis (Shi, 2021). Removal of TR enables premature metamorphosis of several adult tissues (Buchholz and Shi, 2018), likely due to the absence of $\mathrm{T}_{3}$-inducible gene repression. This result supports the role of unliganded $\mathrm{TR}$ to avoid precocious metamorphosis for proper tadpole growth. Finally, removal of TR prevents the disappearance of tadpole-specific tissues (Shibata et al., 2020, 2021).

\section{Involvement of Corticosteroids}

Glucocorticoids (GC) are also essential during anuran metamorphosis. In Xenopus laevis tadpoles, corticosterone concentration is high during pre-metamorphosis, decreases during pro-metamorphosis and increases again during metamorphic climax (Jaudet and Hatey, 1984; Jolivet-Jaudet and Leloup-Hâtey, 1986; Kloas et al., 1997; Glennemeier and Denver, 2002). However, the actions of GC on anuran development are difficult to dissect because of their involvement in many biological processes. Thus, GC inhibit growth, both in pre- and pro-metamorphic tadpoles and the administration of exogenous GC to pre-metamorphic tadpoles inhibits the emergence of lower limbs (Kobayashi, 1958). However, the use of drugs which antagonize the molecular action of GC or prevent the production of GC by the adrenals, inhibits metamorphosis (Kikuyama et al., 1982).

During metamorphosis, GC act through glucocorticoid receptors (GR) that have dynamic and tissue-specific expression profiles (Krain and Denver, 2004). In the tail, GR expression follows the concentration profile of GC, but in the gut and brain the number of transcripts were constant during prometamorphosis, and slightly decreased or increased, respectively, during climax. GR knockout in Xenopus leads to complete abrogation of the corticosterone-responsive gene induction by exogenous hormone (Sterner et al., 2020). In addition, tadpoles lacking GR developed faster than wild-type sibling until forelimb emergence. Then, they developed more slowly and died at the climax of metamorphosis, indicating that GR is required for metamorphosis and control the developmental rate. The essential requirement of the HPA axis was confirmed with the gene-editing disruption of the pomc gene (Sterner et al., 2020). Mutant tadpoles had a reduced level of plasma corticosterone at metamorphosis, as well as lower expression of the corticosteroneresponsive genes. Last but not least, these tadpoles had reduced rates of growth and development that finally led to death, late during metamorphosis at the time of tail resorption. 


\section{Interactions Between Thyroid Hormones and Corticosteroids}

Although $\mathrm{TH}$ are the trigger for metamorphosis and are required throughout this process (Sachs and Buchholz, 2017), their actions strongly intersect with those of CS (Sachs and Buchholz, 2019). Stressors such as predation or pond desiccation can be experienced by tadpoles and cause activation of the HPI axis (Glennemeier and Denver, 2002). In the tadpole, the synthesis and release of TSH by the anterior pituitary is under the control of CRH (Denver, 1993, 2021), as in other nonmammalian vertebrates (De Groef et al., 2006). When injected to prometamorphic Bufo arenarum larvae, $\mathrm{CRH}$ is able to accelerate metamorphosis, likely by direct action on both TSH and ACTH pituitary cells (Miranda et al., 2000). This dual role of CRH allows the tadpole to modulate the rate of metamorphosis in response to environmental stimuli (Denver, 1997). CS are closely linked to metamorphosis by delaying or accelerating its rate of progression. Elevation in circulating CS during the pre-metamorphic stage slows tadpole growth (Denver, 2017). However, during prometamorphosis, tadpoles increase the production of TH and CS in response to environmental stress, and are therefore able to accelerate metamorphosis, which can allow the animal to escape a deteriorating larval habitat by transitioning to the next life history stage (Denver, 1997, 2009; Denver et al., 2009; Kulkarni and Buchholz, 2014). Remarkably, CS are capable of triggering metamorphosis in Buffo boreas (Hayes et al., 1993). This action is probably due to the endogenous levels of $\mathrm{TH}$ with which GC are able to act synergistically, but insufficient, on their own, to induce the metamorphosis.

How does the crosstalk between TH and CS occur? CS are known to promote the expression of activating deiodinases and repress the expression of inactivating deiodinases, thus contributing to the accumulation of active $\mathrm{T}_{3}$ in target tissues. This model has long been the basis for explaining the potentiating effect of GC on metamorphosis (Galton, 1990). Furthermore, GC can also act in synergy with $\mathrm{TH}$ via cross-regulation at the level of their respective nuclear receptors. GC are able to increase the binding capacity of $\mathrm{T}_{3}$ in cell nucleus (Suzuki and Kikuyama, 1983) and the amount of $\operatorname{tr} \beta$ transcripts in the tail, brain and intestine (Bonett et al., 2010). Conversely, the expression of GR seems to be partly controlled by $\mathrm{TH}$ depending on the tissues observed: while in the brain and intestine, treatment with $\mathrm{T}_{3}$ induces a decrease in the expression of GR, the opposite occurs in the tail (Krain and Denver, 2004). These results suggest that $\mathrm{CS}$ are able to increase the sensitivity to $\mathrm{TH}$ in some tissues, thus accelerating metamorphosis. These actions are synergistic with low concentrations of TH (Bonett et al., 2010). Brown et al. (2014) reported similar hormonal synergy during larval development in fish.

Other genes expressed during metamorphosis are synergistically regulated by $\mathrm{TH}$ and CS (Kulkarni and Buchholz, 2012; Bagamasbad et al., 2015), some through direct transcriptional regulation by liganded TR and GR. One of the best studied examples of this type of regulation is the transcription factor krüppel-like factor 9 (Klf9), which is directly and synergistically regulated by $\mathrm{TH}$ and CS via an ultra-conserved super enhancer located upstream of the transcription start site (Bonett et al., 2009; Bagamasbad et al., 2015). Klf9 strongly enhances TR $\beta$ autoinduction in tadpole tissues, among other roles modulating gene transcription and hormone action during metamorphosis (Hu et al., 2016). Other genes show synergistic regulation by $\mathrm{TH}$ and $\mathrm{CS}$ in tadpole tissues, but whether their protein products function to modulate the rate of metamorphosis requires further study (Kulkarni and Buchholz, 2012, 2014).

Finally, the recent results with tadpoles lacking pomc reinforce the inseparable link between $\mathrm{TH}$ and GC at metamorphosis (Sterner et al., 2020). Tadpoles lacking pomc had reduced expression levels of TH-responsive genes such as $k l f 9$ and $\operatorname{tr} \beta$. Even more significant, mutant death at metamorphosis is rescued by exogenous $\mathrm{TH}$, suggesting a strong entanglement of the signaling by both hormones.

\section{First/Primary and Secondary Metamorphoses in Teleost Fishes}

In fishes, two types of metamorphoses can be observed. Both types involve various morphological, physiological and behavioral modifications that preadapt the animal to life in a new environmental niche/habitat, but occur at different life-stages. First/primary metamorphosis typically occurs in elopomorphs and pleuronectiforms, during larval stage and is so-called larval metamorphosis. Secondary metamorphosis occurs in juveniles of some diadromic migratory teleosts and involves less drastic morphological changes. This is the case of smoltification in anadromous salmonids, which allows the transition from a juvenile ecophase in freshwater to the next ecophase in the ocean.

\section{Larval Metamorphosis in Teleosts: The Example of Flatfish}

Beside the striking larval metamorphosis in eels and flatfishes, studies also report developmental changes controlled by $\mathrm{TH}$ during larval to juvenile transition in various teleosts such as grouper Epinephelus coioides (de Jesus et al., 1998), seabream (Campinho et al., 2010), gobiid Sicyopterus lagocephalus (Taillebois et al., 2011), or clownfish Amphiprion percula (Salis et al., 2021). Our review will focus on the well-known pleuronectiform/flatfish metamorphosis. Larval metamorphosis with the migration of one eye to the opposite side of the head is unparalleled in vertebrate development (Inui and Miwa, 2012). Spectacular morphological changes are accompanied by behavioral (pelagic to benthic life and locomotion) and physiological (such as development of gastrointestinal tract to adapt to the novel food resources in a new habitat) changes.

\section{Involvement of Thyroid Hormones}

In the Japanese flounder Paralichthys olivaceus, larval tissue $\mathrm{T}_{4}$ and $\mathrm{T}_{3}$ concentration increases gradually during prometamorphosis, and rises sharply at the beginning of climax, reaching highest level at climax (Miwa et al., 1988; Tanangonan et al., 1989; Tagawa et al., 1990; de Jesus et al., 1991). A similar surge of tissue $\mathrm{TH}$ concentration at metamorphic climax is reported in spotted halibut, Verasper variegatus (Hotta et al., 2001a,b), Atlantic halibut Hippoglossus hippoglossus 
(Einarsdóttir et al., 2006), and summer flounder, Paralichthys dentatus (Schreiber and Specker, 1998).

Treatments of flatfish by $\mathrm{TH}$ or anti-thyroid drug have demonstrated the involvement of TH in many metamorphic changes (Inui and Miwa, 2012). One of the most striking examples concerns skeleton development (shortening of fin rays, eye migration and asymmetry). The elongated fin rays at the anterior end of the dorsal fin shorten to reach similar length to other fin rays. Manipulation of $\mathrm{T}_{4}$ availability disrupts premetamorphic Japanese flounder larvae shortening of elongated fin rays (Inui and Miwa, 1985; Miwa and Inui, 1987; de Jesus et al., 1990). Administration of $\mathrm{T}_{4}$ to pre-metamorphic larvae accelerates eye migration (Inui and Miwa, 1985; Miwa and Inui, 1987; Solbakken et al., 1999). In addition, Schreiber and Specker showed a stage-specific developmental response to $\mathrm{TH}$, with a more pronounced effect in the induction of eye migration at earlier stages (Schreiber and Specker, 1998). Campinho et al. (2018) gave the first evidence of a TH-responsive asymmetric center located in the anterior head region that is correlated with asymmetric development during metamorphosis of flatfish.

In Japanese flounder, expression of $\operatorname{tr} \alpha A$ and $\operatorname{tr} \beta s(\operatorname{tr} \beta 1$ and $\operatorname{tr} \beta 2$ ) genes increase rapidly at metamorphic climax; while expression of $\operatorname{tr} \alpha A$ peaks at climax and decreases thereafter (like $\mathrm{T}_{4}$ content), expression of $\operatorname{tr} \beta s$ peak at post-climax and remains high in metamorphosed juveniles; in contrast, expression of $\operatorname{tr} \alpha B$ remains low throughout larval development (Yamano and Miwa, 1998). In the turbot, Scophthalmus maximus, tra, but not $\operatorname{tr} \beta$, expression is up-regulated at metamorphic climax (Marchand et al., 2004). In contrast, studies in two other flatfishes, the halibut (Galay-Burgos et al., 2008) and the Senegalese sole Solea senegalensis (Isorna et al., 2009; Manchado et al., 2009), describe a situation similar to that in amphibian with only $\operatorname{tr} \beta$ expression showing a peak during metamorphosis.

$\mathrm{DIO} 2$ activity and dio2 expression increase during sole metamorphosis, while $\mathrm{DIO} 3$ activity and dio3 expression decline at mid-late metamorphic period (Isorna et al., 2009). These developmental profiles of deiodinases coincide with the rise of TH levels observed. In this species, there is an asymmetric expression of dio 2 and $T R \beta$ in the head, which coincides with the head region where asymmetric development of bone and brain occurs (Campinho et al., 2018). In the Japanese flounder, dio1 is expressed in liver from pro-metamorphosis to early climax, while dio2 is expressed in limited regions of the eyes, tectum and skeletal muscle from pro-metamorphosis to postclimax, and dio3 in skeletal muscle and gastric gland blastemas at metamorphic climax (Itoh et al., 2010).

\section{Involvement of Corticosteroids}

Data support a role of CS in larval flatfish metamorphosis. Whole body cortisol concentration in Japanese flounder increases during pro-metamorphic stage, reaching a peak level at climax, and decreases thereafter to about half of the maximal level (de Jesus et al., 1991). In vitro cortisol treatment of cultured dorsal ray fins from Japanese flounder is not effective alone on inducing metamorphic-like changes such as resorption of the fin rays (de Jesus et al., 1990). In contrast, in vivo cortisol treatment via water of pro-metamorphic flounder larvae for 15 days is not able to trigger some of the changes observed during metamorphosis, like settling (benthic) behavior and eye migration, but does induce shortening of second fin ray (de Jesus et al., 1990). Administration of cortisol via water to spotted halibut increases the occurrence of ambicolored juveniles by inducing the development of adult type pigment cells on the blind side of fishes (Yamada et al., 2011). In cortisol-implanted juvenile Senegalese sole, hepatic and renal DIO2 activities are enhanced, suggesting that CS can be key regulator of extrathyroidal $\mathrm{T}_{3}$ production in this species (Arjona et al., 2011). This regulation is likely to occur also during sole larval metamorphosis.

\section{Interactions Between Thyroid Hormones and Corticosteroids}

Few data are available concerning the interactions between TH and GC in the control of teleost larval metamorphosis. In the Japanese flounder, a permissive effect of cortisol on thyroid hormone action is observed during metamorphosis (de Jesus et al., 1990). Indeed, cortisol alone does not affect the shortening of fin rays in vitro, whereas when added together with $\mathrm{T}_{4}$ or $\mathrm{T}_{3}$, it enhances its rate compared to $\mathrm{T}_{4}$ or $\mathrm{T}_{3}$ alone. This permissive effect of cortisol on $\mathrm{TH}$ action was not reported in vivo (de Jesus et al., 1990). Combined $\mathrm{T}_{4}$ and cortisol treatment does not induce either synergistic effects on settling behavior and eye migration, compared to $\mathrm{T}_{4}$ treatment alone (de Jesus et al., 1990). The authors concluded that it may be due to sufficient production of endogenous cortisol by larval interrenal. Future studies should aim at investigating the mechanisms of $\mathrm{CS} / \mathrm{TH}$ interactions in teleost metamorphoses as deciphered in amphibians.

\section{Secondary Metamorphosis in Teleosts: Example of Smoltification in Salmonids}

Smoltification is the transition of sedentary juvenile parr into downstream migratory smolt, which will pursue its growth phase in the ocean. Smoltification gathers many changes, morphological ones, such as body silvering and fin darkening, behavioral ones, with swimming activity in open space, formation of schools and downstream migration, and physiological ones related to adaptation to seawater and imprinting (Hoar, 1976, 1988; Boeuf, 1993; McCormick, 2012; Rousseau et al., 2012).

\section{Involvement of Thyroid Hormones}

Even if some authors do not consider salmonid smoltification as a metamorphosis (Bishop et al., 2006), this transformation from parr to smolt involves major changes and is necessary for the fish to reach its next habitat and survive in a new environment. Moreover, many parallel features exist between flatfish metamorphosis and salmonid smoltification, as reviewed by Björnsson et al. (2012). Lastly, control by TH is crucial in smoltification.

In salmonids, a rise of plasma $\mathrm{T}_{4}$ and/or $\mathrm{T}_{3}$ levels is observed at the time of smoltification (McCormick et al., 2009; Björnsson et al., 2012). Manipulation of TH levels by administration of $\mathrm{T}_{4}, \mathrm{~T}_{3}$ or anti-thyroid drugs supports a major role of $\mathrm{TH}$ in many smoltification-related morphological, behavioral and physiological changes, such as metabolism, olfaction, change in visual pigments, swimming behavior and downstream migration (McBride et al., 1982; Rousseau et al., 2012). The examples of TH-induced changes, given here, are necessary for avoiding 
predation and for adaptation to a new environment, seawater (SW). A pioneer study showed that intramuscular injection of mammalian thyroid extract or TSH induces silvery smolt stage in rainbow trout (Robertson, 1949). Following studies confirmed that exogenous TH (Miwa and Inui, 1983, 1985; Ikuta et al., 1985; Coughlin et al., 2001) and TSH (rainbow trout: Premdas and Eales, 1976) induce body silvering. The silvering of the body is due to the deposition in the skin of purines, hypoxanthine and guanine, the level of which is increased by $\mathrm{T}_{4}$ treatment in masu salmon O. masou (Ura et al., 1994). Early evidence reported the involvement of TH in salinity preference: TSH-treated coho salmon $O$. kisutch shows a change from freshwater (FW) to SW-preference, while the contrary is observed in pink salmon O. gorbuscha treated by an anti-thyroid drug (Baggerman, 1963). Similarly, $\mathrm{T}_{4}$ treatment increases the salinity preference in coho salmon (Iwata et al., 1990). In Atlantic salmon, $\mathrm{T}_{3}$ increases SW survival (Saunders et al., 1985).

Interestingly, a large peak of expression of $t \operatorname{sh} \beta 1 b$ during Atlantic salmon smoltification, at the time of the initiation of the downstream migration, has recently been demonstrated, with no change in the expression of the paralog $t \operatorname{sh} \beta 1 a$, suggesting the involvement of $t s h \beta 1 b$ at smoltification, possibly in the initiation of migration (Fleming et al., 2019). In addition, the expression of pituitary $t \operatorname{sh} \beta 1 b$, and not $t \operatorname{sh} \beta 1 a$, is induced by long dayphotoperiod (16h of light and $8 \mathrm{~h}$ of dark) in Atlantic salmon (Irachi et al., 2021).

Expression of TR has been detected in all the tissues involved in smoltification-related changes (Marchand et al., 2001; Jones et al., 2002; Raine et al., 2005; Harada et al., 2008). Expressions of $\operatorname{tr} \alpha$ and $\operatorname{tr} \beta$ show no drastic change between the different stages of smoltification in brain, liver, eyeball, and skin in coho salmon (Harada et al., 2008). In contrast, the olfactory epithelium of masu salmon presents more T3 binding sites at smolt than at parr and pre-smolt stages, suggesting that olfactory tissues may be particularly sensitive to $\mathrm{TH}$, related to a possible role in imprinting of natal stream odors in order to migrate back there to reproduce (Kudo et al., 1994). DIO3 activities are enhanced at smoltification in liver (Eales et al., 1993; Sweeting et al., 1994; Specker et al., 2000) and gill (Sweeting et al., 1994). The expression of one of the $4 \mathrm{R}$-paralog, dio $2 b$, increases in the brain in zones of cell proliferation during smoltification in response to photoperiod (Lorgen et al., 2015; Irachi et al., 2021).

\section{Involvement of Corticosteroids}

The cells of interrenal tissue undergo hypertrophy during smoltification (for review: (Specker, 1982). Pituitary corticotropic cells are also activated during smoltification in Atlantic salmon (Olivereau, 1975). Plasma cortisol levels are low in winter, increase during spring at the time of smoltification and decline from July to September (Langhorne and Simpson, 1981, 1986; Specker and Schreck, 1982; Barton et al., 1985; Virtanen and Soivio, 1985; Young et al., 1989; Nagae et al., 1994; Sundell et al., 2003). Maximal in vitro responsiveness of interrenal tissue to ACTH is observed in April in coho salmon (Young, 1986).

As for $\mathrm{TH}$, we will concentrate on the effects of HPI manipulation on pigmentation and osmoregulation. Injection of ACTH in Atlantic salmon can induce darkening of dorsal, pectoral and caudal fins, but neither ACTH nor cortisol have an effect on body silvering (Langdon et al., 1984). Prolonged cortisol treatment in pre-smolt salmons increase $\mathrm{Na}^{+} / \mathrm{K}^{+}$ATPase activity in the gill (Richman et al., 1987; Madsen, 1990) and in gut (Madsen, 1990; Veillette and Young, 2005). In vitro, cortisol treatment maintains $\mathrm{Na}^{+} / \mathrm{K}^{+}$-ATPase activity, which declines in controls, in tissue culture of FW-adapted sockeye salmon intestine (Veillette and Young, 2005). Injections of FWAtlantic salmon with cortisol increase the expression of claudins (tight-junction proteins) involved in the remodeling of the gill in response to salinity changes (Tipsmark et al., 2009). Using primary cultures of Atlantic salmon gill tissue, a stimulatory effect of cortisol is observed on the expression of claudins; an effect blocked by GR antagonist, mifepristone (or RU486), suggesting the involvement of a glucocorticoid type receptor (GR) (Tipsmark et al., 2009).

An increase in gill GR concentration and $g r$ expression is reported during smoltification in all studied salmonid species (McLeese et al., 1994; Shrimpton and Randall, 1994; Shrimpton, 1996; Mazurais et al., 1998; Shrimpton and McCormick, 1998, 2003; Mizuno et al., 2001; Kiilerich et al., 2007). This increase occurs before the increase in plasma cortisol, which could explain the increased responsiveness of gill tissue to cortisol observed in early spring in coho and Atlantic salmon (McCormick et al., 1991) and also demonstrated in vitro in rainbow trout (Shrimpton and McCormick, 1999).

\section{Interactions of Thyroid Hormones and Corticosteroids}

Studies report interactions between HPT and HPI during smoltification. For example, TH can increase CRH neurogenesis during smoltification in Atlantic salmon (Ebbesson et al., 2011), suggesting a positive effect of TH on HPI. Cortisol treatment can lower plasma $\mathrm{T}_{3}$ (but not plasma $\mathrm{T}_{4}$ ) in coho salmon (Vijayan and Leatherland, 1989), during smoltification (Redding et al., 1991). The increases of $t r$ mRNA and TR protein expressions and of plasma TH levels, observed during transfer from FW to SW, are lower in cortisol-injected smolt sockeye salmon compared to controls (Shin et al., 2014), suggesting some antagonistic/negative effects of cortisol on TH action.

\section{Egg Hatching in Sauropsids}

Thyroid hormones have an important role in fish egg hatching (tilapia: Reddy and Lam, 1991; Walpita et al., 2007; zebrafish: Heijlen et al., 2014; for review: Brown et al., 2014), but it will not be considered in this review, as egg hatching in fish implies less drastic changes of environmental conditions, as compared to sauropsids. In contrast, hatching in oviparous sauropsids, such as birds and reptiles, is characterized by a transition from a "protected" aqueous environment to a terrestrial environment exposed to desiccation and predation.

\section{Egg Hatching in Birds}

\section{Involvement of Thyroid Hormones}

Considering the implication of $\mathrm{TH}$ in egg hatching, one must differentiate precocial from altricial birds (McNabb, 2006; De Groef et al., 2013). Precocial species (e.g., chicken Gallus domesticus, Japanese quail Coturnix japonica, bobwhite 
quail Colinus virginianus, turkey Melleagris gallopavo, mallard Pekin duck Anas platyrhynchos, goose Anser anser) have youngs that are immediately mobile and independent after hatching. In contrast, youngs of altricial birds (e.g., European starling Sturnus vulgaris, Ring dove Streptopelia risorii, red-winged blackbird Agelaius phoeniceus, great tit Parus major) need to be fed and thermoregulated by their parents in the nest (Starck and Ricklefs, 1998).

A gradual increase in plasma TH concentrations of the embryos to a peak is observed in precocial birds during the peri-hatch period (for review McNabb, 2006). In contrast, in altricial birds, circulating concentrations of $\mathrm{TH}$ are low during embryonic life and at hatching, and only increase after hatching (McNabb et al., 1984; Silverin and Rudas, 1996; Výboh et al., 1996; Olson et al., 1999).

Manipulation of egg TH levels influences avian hatching time. Injection of antithyroid drugs in the yolk sac of chick embryos retards hatching, and $\mathrm{T}_{4}$ fully neutralizes these effects (Grossowicz, 1946; Adams and Bull, 1949; Romanoff and Laufer, 1956; Sinha et al., 1959; Balaban and Hill, 1971; Haba et al., 2011). In turkey, $T_{4}$ or $T_{3}$ injected to fertile eggs at Day 0 of incubation depresses hatchability, while improving it when administered at Day 25 of incubation out of a 28 -day incubation period (Christensen, 1985). In Pekin duck, injection of $\mathrm{T}_{3}$ results in earlier hatching, while injection of antithyroid drug delays hatching (Sirsat and Dzialowski, 2020). In Japanese quail, injection of $\mathrm{T}_{4}$ alone or with $\mathrm{T}_{3}$ doubles hatching success (Sarraude et al., 2020). Similarly, in a type 2 semi-altricial development model, the rock pigeon Columba livia, injection of a mixture of both $\mathrm{T}_{3}$ and $\mathrm{T}_{4}$ early results in higher hatching success but unchanged hatching time (Hsu et al., 2017).

In chicken, a differential temporal expression pattern of the three TR is observed. TR $\alpha$ mRNAs are detected as early as gastrula stage and throughout development in many embryonic tissues (Forrest et al., 1990). TR $\beta 0$ mRNAs appear later in embryonic life and are restricted to brain, eye, lung, and yolk sac (Forrest et al., 1990). TR $\beta 2$, a N-terminal variant of TR $\beta 0$, is predominantly expressed in retina (Sjöberg et al., 1992). The minimal generation of T3 until just before hatching is primarily due to the presence of DIO3 in chicken embryo liver (Galton and Hiebert, 1987). Hepatic DIO1 activity increases up to hatching and decreases thereafter, while hepatic DIO3 activity increases during embryogenesis, then decreases before hatching to remain low at post-hatching (Darras et al., 1992; Reyns et al., 2003). Dynamics of expression in deiodinases in the choroid plexus of the developing chicken brain have been reported: diol and dio2 mRNA levels increase over time to reach a peak around hatching, while dio3 expression is high before hatching and decreases at hatching to re-increase up to 1 day post-hatching (Van Herck et al., 2015).

\section{Involvement of Corticosteroids}

An increase of avian embryonic GC is observed around the time of hatching in plasma (Wise and Frye, 1973; Kalliecharan and Hall, 1974; Siegel and Gould, 1976; Marie, 1981; Scott et al., 1981; Tanabe, 1982; Tanabe et al., 1983, 1986; Wentworth and Hussein, 1985; Porter et al., 2007), in adrenal glands (Tanabe et al., 1983,
1986), and in feces (Frigerio et al., 2001), and in adrenocortical cells in culture (Carsia et al., 1987).

Most studies investigating the effects of exogenous treatment of embryos with corticosterone in birds look at the postnatal growth and behavior linked to stress response (Rubolini et al., 2005; Saino et al., 2005; Freire et al., 2006; Hayward et al., 2006; Janczak et al., 2006; Henriksen et al., 2013; Zimmer et al., 2013; Weber et al., 2018). However, a few looked at the effects of GC treatment on hatching. Injection of corticosterone in the yolk sac 2 days prior to hatching shortens incubation time and increases hatchability in turkey (Wentworth and Hussein, 1985). In contrast, dipping fertile eggs in corticosterone prevents hatching in chicken (Mashaly, 1991). Elevation of plasma corticosterone levels by mean of synthetic GC (dexamethasone) injection during the final stages of incubation in chicken embryos increases or shortens incubation period when administered, on Day 16 and Day 18, respectively (Tona et al., 2007). In Japanese quail, incubation period is shortened in eggs laid by corticosterone-implanted hens (Schmidt et al., 2009). Chicken lung becomes sensitive to corticosterone prior hatching (Hylka and Doneen, 1983). Corticosterone treatment triggers prehatching stimulation of surfactant phospholipid synthesis (Hylka and Doneen, 1983). The first two studies reporting the cloning and developmental expression of pituitary GR in bird (chicken) gave different results: While Kwok et al. (2007) demonstrate constant expression of GR during embryonic period, other authors show an increase of GR mRNA levels (Porter et al., 2007).

Interactions Between Thyroid Hormones and Corticosteroids Creating hypothyroidism in chick embryos induces a cortical atrophy and medulla hypertrophy in adrenal gland (Kingsbury et al., 1955). Injection of cortisol onto the allantoic membrane of 17 or 16-days old chicken embryos induces the same premature maturational changes in $T_{3}$ and $T_{4}$ metabolism observed naturally on 19-20-days old embryos, meaning a decrease of DIO3 preserving the $\mathrm{T}_{3}$ formed, and an increase of DIO2 sparing $\mathrm{T}_{4}$ (Borges et al., 1980). The administration of either dexamethasone or corticosterone, or ACTH to chicken embryos increase plasma $\mathrm{T}_{3}$ concentrations and hepatic DIO2 activity (Decuypere et al., 1983) and increase plasma $\mathrm{T}_{3}$ levels, decreased plasma $\mathrm{T}_{4}$, decreased hepatic DIO3 activity and increased hepatic DIO1 activity (Darras et al., 1996).

\section{Egg Hatching in Reptiles Involvement of Thyroid Hormones}

An increase in TH correlates with hatching in saltwater crocodile Crocodylus porosus (Shepherdley et al., 2002). In the grass snake Natrix natrix, the activity of the embryonic thyroid exhibits the features of a fully active gland at the time of hatching (Rupik, 2011). Injection of antithyroid drug into embryos of the snapping turtle Chelydra serpentina gives enlarged thyroid gland and delays hatching time (Dimond, 1954). Eggs of red-eared turtle, Trachemys scripta, treated with $\mathrm{T}_{3}$, have shortened incubation duration (Sun et al., 2016). Embryos from Murray River shortnecked turtle, Emydura macquarii, exposed to $\mathrm{T}_{3}$, hatch earlier than untreated ones (McGlashan et al., 2017). Treatment of 
saltwater crocodile embryos with $\mathrm{T}_{3}$ increases DIO1 activity in liver and DIO2 in kidney (Shepherdley et al., 2002). Treatment with $\mathrm{T}_{3}$ stimulates the secretion of phosphatidylcholine (PC, the major component of pulmonary surfactant) in sea turtle, Chelonia mydas (Sullivan et al., 2001). In saltwater crocodile, pre-treatment with $\mathrm{T}_{3}$ increases surfactant phospholipids in lung (Sullivan et al., 2002a).

\section{Involvement of Corticosteroids}

An increase of corticosterone is observed from the last third of incubation to hatching in American alligator Alligator mississippiensis (Medler and Lance, 1998; Jennings et al., 2000). In contrast, a decrease in corticosterone is observed at hatching in saltwater crocodile (Shepherdley et al., 2002). Yolk corticosterone concentrations peak near the time of hatching in the tree lizard, Urosaurus ornatus (Jennings et al., 2000) and in sea turtles (Owens and Morris, 1985). In the tree lizard, treatment with corticosterone accelerates egg hatching (Weiss et al., 2007). Treatment with dexamethasone of saltwater crocodile embryos decreases DIO1 activity in kidney, DIO2 activity in liver and in kidney and DIO3 activity in liver (Shepherdley et al., 2002). Dexamethasone alone increases phospholipids from pulmonary surfactant in sea turtle when administered in ovo during late incubation (Sullivan et al., 2001). It also stimulates the secretion of phosphatidylcholine in vitro in saltwater crocodile (Sullivan et al., 2002a) and in lizard bearded dragon Pogona vitticeps (Sullivan et al., 2002b). In Chinese alligator Alligator sinensis, variations of the mRNA levels for $g r$ in kidney, liver, and heart during embryonic development suggest a potential role for GC in tissue maturation before hatching (Izaz et al., 2021).

\section{Interactions Between Thyroid Hormones and Corticosteroids}

Treatment with dexamethasone and $\mathrm{T}_{3}$ of saltwater crocodile embryos has effects on deiodinase activities: decrease of DIO1 activity in kidney, decrease of DIO2, and DIO3 activities in liver (Shepherdley et al., 2002). In the sea turtle Chelonia mydas, the secretion of phosphatidylcholine is stimulated by a combination of $\mathrm{T}_{3}$ and dexamethasone before hatching (Sullivan et al., 2001). Similar results were obtained in the saltwater crocodile (Sullivan et al., 2002a) and in the lizard Pogona vitticeps (Sullivan et al., $2002 \mathrm{~b}$ ). All these data demonstrate the involvement of both $\mathrm{TH}$ and GC in the regulation of surfactant maturation in reptiles (Sullivan et al., 2003). Sullivan et al. (2003) reviewed the control of pulmonary surfactant and stated that dexamethasone and $\mathrm{T}_{3}$ are crucial stimulators of surfactant production during embryonic development throughout evolution.

\section{Birth in Mammals}

\section{Involvement of Thyroid Hormones}

During most of the gestation in human, $\mathrm{T}_{4}$ is converted in $\mathrm{rT}_{3}$, while toward term, developmental changes in tissue deiodinase activity occur, leading to preferential deiodination of $\mathrm{T} 4$ to $\mathrm{T} 3$ (instead of $\mathrm{rT}_{3}$ ) and rise in plasma $\mathrm{T}_{3}$ concentration near term (Forhead and Fowden, 2014). In contrast, in the rat, circulating $\mathrm{T}_{3}$ concentrations do not increase before birth (Dubois and Dussault, 1977; Harris et al., 1978; Lamers et al., 1986). Comparison of hormonal profiles during the perinatal period in two closely related murine species with distinct modes of development (altricial vs. precocial), the rat (altricial), and the spiny mouse Acomys cahirinus (precocial) allowed to show a correlation between perinatal increase in $\mathrm{T}_{3}$ levels and precocial timing of birth (Lamers et al., 1986).

$\mathrm{TH}$ have a major regulatory role on fetal growth (Forhead and Fowden, 2014), and maturation of the central nervous system (Patel et al., 2011; Stenzel and Huttner, 2013). Furthermore, maternal hypothyroidism is associated with increased rates of respiratory distress syndrome in new-born (Casey et al., 2005; Männistö et al., 2013) and cardiorespiratory disorder (Rousseau et al., 2019). In various mammalian species, $\mathrm{TH}$ change the synthesis of the components of surfactant (Ballard et al., 1984; Das et al., 1984; Warburton et al., 1988; Gilbert et al., 2001; Van Tuyl et al., 2004). TH are also involved in the intestinal structural development (Trahair and Sangild, 1997; Sirakov and Plateroti, 2011; Sirakov et al., 2014). Specific TR $\alpha 1$ loss-offunction leads to low development and impaired activity of murine intestinal stem cells in culture (Godart et al., 2021). In addition, in vivo treatment confirms the positive action of $\mathrm{T}_{3}$ on intestinal crypt cell proliferation and demonstrates its key action in modulating the number of stem cells, the expression of their specific markers and the commitment of progenitors into lineage-specific differentiation (Godart et al., 2021).

\section{Involvement of Corticosteroids}

An increase of plasma fetal GC is detected near parturition in many mammals (Alexander et al., 1968; Mulay et al., 1973; Lamers et al., 1986; Silver and Fowden, 1989; Yoon et al., 1998). The involvement of HPA axis in the timing of birth is first evidenced in ovines (Van Rensburg, 1967; Barnes et al., 1977). Furthermore, premature delivery is induced by injection of ACTH or corticosteroids into the ovine fetus (Van Rensburg, 1967; Halliday and Buttle, 1968; Liggins, 1968, 1969) as well as in fetal piglet (Bosc, 1973). More recently, the use of antalarmin, a CRH-R type I antagonist, can delay the onset of parturition in sheep, which suggests that CRH is involved in the induction of parturition in this species (Chan et al., 1998).

The many roles of GC on organ maturation have been the subjects of recent reviews (Fowden and Forhead, 2015; Fowden et al., 2016; Jellyman et al., 2020). As for TH, we will concentrate on GC involvement in lung and gastro-intestinal tract (GIT) maturations, which are crucial to cope with the change of environment (from aquatic to terrestrial) and of nutrition (from parenteral to enteral), respectively. In lambs born prematurely by infusion of dexamethasone, partial aeration of the lungs is noted, suggesting an accelerated appearance of surfactant activity (Liggins, 1969). Infusion of ACTH into one of twin pairs of lamb fetuses accelerates the morphological changes, that would normally occur in the lung, before birth (Sundell et al., 1979). GC treatment changes the synthesis of the phospholipid and protein components of surfactant (Warburton et al., 1988; Gilbert et al., 2001). At birth, there is a shift from mainly parenteral nutrition in the fetus (via the placenta) to enteral nutrition in the neonate, and the GIT has to prepare during gestation for coping with this change. This prenatal development of GIT is regulated by GC (Trahair and Sangild, 1997; Sangild et al., 2000). After bilateral 
adrenalectomy of fetal sheep, growth of mucosal structures and villus height are reduced in the small intestine (Trahair et al., 1987a). After infusion of cortisol, no change in enterocyte morphology is detected, but the proportion of crypt cells and the migration of enterocytes are increased (Trahair et al., 1987b). In addition, cortisol influences the prenatal development of gastric acid and gastrin secretion, and of GIT hydrolase activities in both the fetal pig and sheep (Trahair and Sangild, 1997; Sangild et al., 2000).

\section{Interactions Between Thyroid Hormones and Corticosteroids}

Before birth, TH and GC synergize for the maturation of various organs, especially the lung, the liver and the brain. This synergism is partly linked to the fact that GC induce local deiodinase expression and activities resulting in the increase of circulating $\mathrm{T}_{3}$ and thus $\mathrm{T}_{3}$ bioavailability (Forhead et al., 2006; Fowden and Forhead, 2009). A synergism of $\mathrm{TRH} / \mathrm{T}_{3}$ and cortisol has been reported on lung maturation in fetal sheep, as infusion of cortisol and TRH (Liggins et al., 1988) or $\mathrm{T}_{3}$ (Schellenberg et al., 1988; Warburton et al., 1988) increase the distensibility and the stability of the lung. In explant culture of human fetal lung, a supraadditive response in the synthesis of surfactant is observed in the presence of both dexamethasone and $\mathrm{T}_{3}$ (Gonzalez et al., 1986).

$\mathrm{T}_{4}$ injection to rats induces a precocious appearance of pepsinogen in the oxyntic gland mucosa and increases acid secretion, while in propylthiouracil-induced hypothyroid pups, pepsinogen content and basal acid secretion are low (Tseng and Johnson, 1986). However, $\mathrm{T}_{4}$ has no such effects in adrenalectomized rats, while corticosterone is able to increase pepsinogen content and basal acid secretion in the absence of normal levels of TH (Tseng and Johnson, 1986).

\section{Comparison of the Involvement and the Interdependence Between Thyroid and Corticosteroid Signaling in Vertebrate Developmental Transitions}

In all the major developmental transitions described here, a common synergistic activation of thyrotropic and corticotropic axes is observed, leading to synchronized increase of $\mathrm{TH}$ and CS production and release (Figure 4). Besides this hormonal activation, increased expression of receptors allows tissues to become more responsive to $\mathrm{TH}$ and $\mathrm{CS}$ in time (Figure 4) to induce morphological, behavioral and physiological changes when needed, meaning just before the animal has to adapt to its new environment and its new way of life. As in all the mechanisms underlying major biological processes, they are conserved along evolution. Thus, the involvement of both $\mathrm{TH}$ and CS signaling is encountered in fish and amphibian metamorphic processes, as well as in egg hatching in sauropsids and birth in mammals (Table 1).

In non-mammalian vertebrates, the neurohormone, corticotropin-releasing hormone $(\mathrm{CRH})$, appears to be potentially a coordinator of activation of both thyrotropic and corticotropic axes, as it is able to simulate thyrotropin production and release as much as corticotropin ones. $\mathrm{CRH}$ may thus be involved in the simultaneous activation of these neuroendocrine axes at the time of developmental transitions in non-mammalian vertebrates, such as fish and amphibian metamorphoses or sauropsid egg hatching (Table 1). It is not the case in mammals, in which the thyrotropic and corticotropic axes are controlled centrally by different hormones, respectively, TRH and CRH. Another difference among vertebrate developmental transitions described in this review may lay in the degree of involvement (triggering vs. permissive) of the two signaling systems and their interdependence. Except perhaps during birth for mammals, corticosteroid signaling seems to be more permissive than crucial, in the way it allows the thyroid signaling to be even more efficient, by elevating the activating deiodinase expression and activities, as well as the expression of $\mathrm{TH}$ receptors. Another difference may be likely due to neofunctionalization of gene paralogs observed after WGD. Duplication of some genes, notably in teleosts, may lead to redistribution of function. For example, the involvement of $t \operatorname{sh} \beta 1 b$ at smoltification in Atlantic salmon, instead of the classical $t s h \beta$ in other vertebrate developmental transitions, or also the relative importance and differential role of the various thyroid hormone receptors between flatfish and amphibian larval metamorphoses.

\section{IMPACT OF ENVIRONMENTAL FACTORS ON POST-EMBRYONIC TRANSITIONS}

\section{Climate Change \\ Water Warming for Population Strictly Dependent on an Aquatic Habitat}

Teleost fish as ectothermic vertebrates show complex responses to temperature variation (Pinsky et al., 2019). Temperature has in teleost fishes a direct effect on oxygen delivery, cardiovascular function, muscle function, food conversion, mitochondria efficiency, and biochemical reaction rates (Little et al., 2020). Fish physiology is thus likely to be affected by increases in average temperature and temperature variability leading to energy metabolism changes with impact on growth and locomotion. All these physiological processes have been associated with thyroid function.

$\mathrm{T}_{3}$ regulates thermal acclimation in zebrafish (Little et al., 2013) with the decrease of metabolism, skeletal muscle function and swimming performance in hypothyroid cold-acclimated $\left(18^{\circ} \mathrm{C}\right)$ but not hypothyroid warm-acclimated $\left(28^{\circ} \mathrm{C}\right)$ animals. The interactions between temperature levels, thyroid conditions and swimming performance are also linked to performance of the heart and oxygen transport (Little and Seebacher, 2014). In the context of global warming, the low sensitivity to $\mathrm{TH}$ at warm temperature is a concern because it may reduce the capacity of zebrafish to match this environmental change. Furthermore, in medaka, exposure until hatching to warm temperatures $\left(32^{\circ} \mathrm{C}\right)$ increases the activation of TH biosynthesis, via TSH (CastañedaCortés et al., 2020), as well as the activation of the stress axis, via CRH (Castañeda-Cortés et al., 2019).

Rainbow trout is a typical cold-water fish species for which seasonally warmer water correlates with a decrease in fry survival 


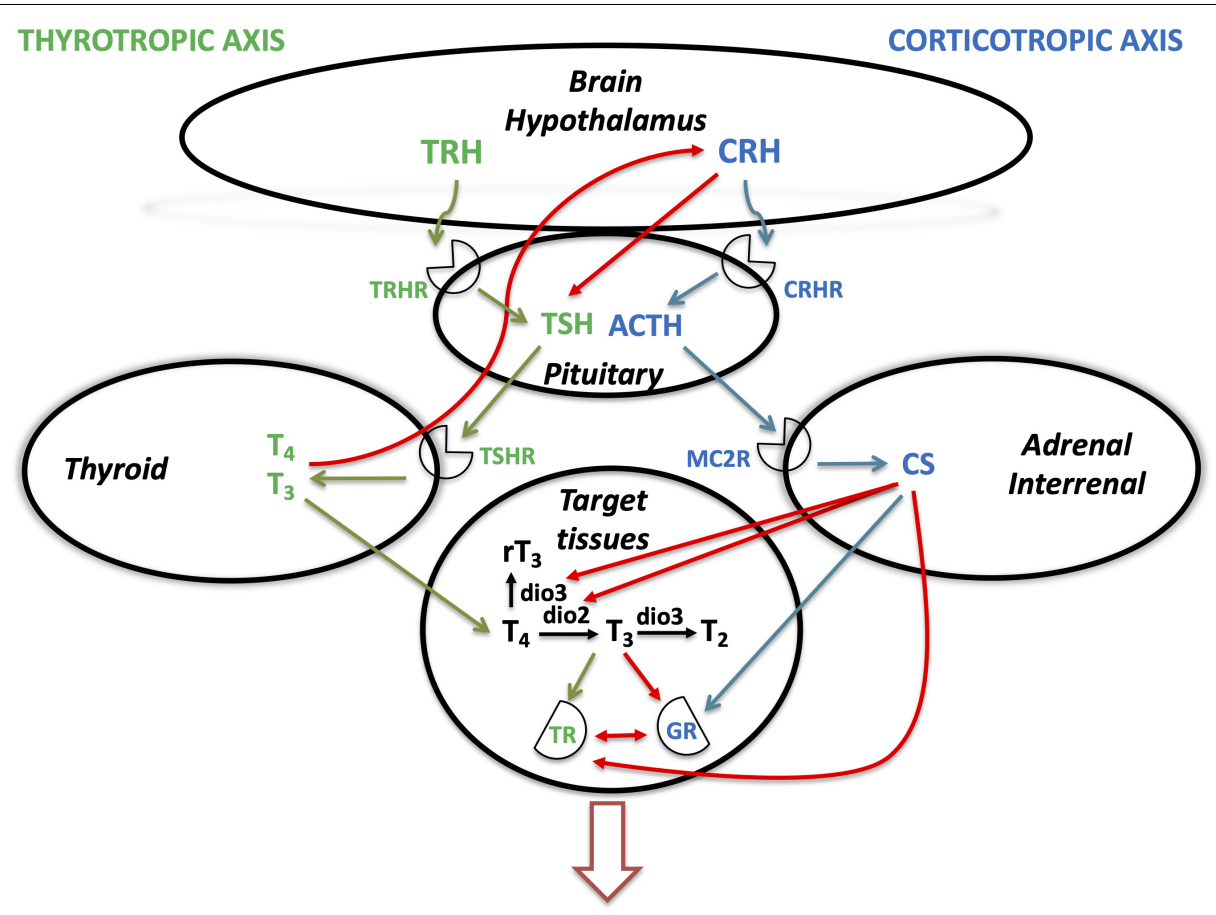

Modulation of the DEVELOPMENT by STRESS

FIGURE 4 | Interactions between thyrotropic and corticotropic axes during vertebrate developmental transitions. The figure illustrates current knowledge on the interactions between the thyrotropic (HPT) and corticotropic (HPA/HPI) axes, during various developmental transitions (amphibian and teleost metamorphoses, sauropsid egg hatching and mammalian birth). $\mathrm{ACTH}$, adrenocorticotropin; $\mathrm{CRH}$, corticotropin-releasing hormone; CRHR, corticotropin-releasing hormone receptor; CS, corticosteroids; dio, deiodinase; GR, glucocorticoid receptor; MC2R, melanocortin receptor 2; MR, mineralocorticoid receptor; $T_{4}$, thyroxine; $T_{3}$, triiodothyronine; $r T_{3}$, reverse triiodothyronine; $T_{2}$, diiodothyronine; TR, thyroid hormone receptor; TRH, thyrotropin releasing hormone; TRHR, thyrotropin releasing hormone receptor; TSH, thyrotropin; TSHR, thyrotropin receptor.

TABLE 1 | Comparison of the interactions between HPT and HPA axes during vertebrate developmental transitions.

\begin{tabular}{|c|c|c|c|c|c|}
\hline & Vertebrates & Amphibian & Teleost & Sauropsid & Mammal \\
\hline & Developmental period & Metamorphosis & Metamorphosis & Egg hatching & Birth \\
\hline \multirow[t]{3}{*}{ HPT axis on HPA/I axis } & $\mathrm{TH}$ on $\mathrm{CRH}$ & + & + & + & + \\
\hline & TH on CS availability & $?$ & $?$ & $?$ & + \\
\hline & TH on GR & + & + & + & + \\
\hline \multirow[t]{3}{*}{ HPAI axis on HPT axis } & $\mathrm{CRH}$ on $\mathrm{TSH}$ & + & + & + & - \\
\hline & CS on TH availability & + & + & + & + \\
\hline & CS on TR & + & + & + & + \\
\hline
\end{tabular}

and an increase of $\mathrm{T}_{3}$ and $\mathrm{T}_{4}$ concentrations (Giroux and Schlenk, 2021). Transcriptome analysis of liver tissues from adult rainbow trout under heat stress $\left(24^{\circ} \mathrm{C}\right)$ and control conditions $\left(18^{\circ} \mathrm{C}\right)$ identifies the differential expression of 428 long non coding RNA some of which can be involved in maintenance of homeostasis or adaptation to stress (Quan et al., 2020). In Atlantic salmon, elevated temperature increases $\mathrm{T}_{4}$ nocturnal levels (Nisenbaum et al., 2020). Thus, future climate changes can induce lower salinity tolerance and accordingly result in poor survival in seawater after smoltification.

To show the wide diversity of the links between global warming and $\mathrm{TH}$, we will give three more examples. First, in the mosquitofish Gambusia holbrooki the thermal acclimation is mediated by TH and leads to decreased mitochondrial efficiency, metabolic rates, and swimming performance (Le Roy and Seebacher, 2020). Second, in the desert fish Amargosa pupfish Cyprinodon nevadensis amargosae, temperature contributes to altered TH levels and morphological development (Lema et al., 2016). We can thus expect that many desert fishes will be vulnerable to rising temperatures because they occupy habitats with already high temperatures. Finally, increased temperature induces a decrease of TH levels in convict surgeonfish Acanthurus triostegus (Besson et al., 2020). The effect on TH levels correlates with affected sensory development leading to higher predation.

Chronic temperature increases (persisting for a long time) are also known to induce acute stress responses in fishes 
(Alfonso et al., 2020). Global warming can cause water freshening from increased freshwater inputs. In Antarctic spiny plunderfish Harpagifer antarcticus, salinities decrease leads to high plasma cortisol levels compare to normal salinity (Vargas-Chacoff et al., 2021). This has implications for fish species that have evolved in stable environmental conditions like in the Antarctic. In a totally different environment, climateinduced bleaching of coral reefs alters anemonefish hormonal stress, resulting in decreased reproductive hormones and severely impacted reproduction (Beldade et al., 2017). Finally, in juvenile brown trout, Salmo trutta, water temperature affects cortisol and GR mRNA levels (Filipsson et al., 2020).

\section{Aquatic and Terrestrial Life Cycle: Warming Leads to Double Penalty}

Amphibians are another ectodermic taxon with complex interactions between costs and benefits of life in the aquatic and terrestrial environments. They are undergoing a precipitous decline linked with environmental pressures including climate change. Many amphibian species exploit temporary or even ephemeral aquatic habitats for reproduction. Survival from desiccation of pond drying is reached by maximizing larval growth and acceleration of development, including precocious metamorphosis.

The western spadefoot toad tadpoles, Pelobates cultripes, usually have long larval period, but it can shorten it in response to pond drying (Gomez-Mestre et al., 2013). Developmental acceleration correlates with increased corticosterone and $\mathrm{TH}$ levels as well as increased $\operatorname{TR} \beta$ levels to increase metamorphic process. Anuran tadpole shows thus phenotypic plasticity in age and size at metamorphosis as a response to temperature variation (Ruthsatz et al., 2020). In Arizona tiger salamander Ambystoma tigrinum, the small increase in temperature tends also to decrease the time to metamorphosis and results in a worse body condition (Park et al., 2016). Plasticity in rates of growth and development is beneficial to allow a more rapid transition into the juvenile stage where rates of mortality are lower. However, early metamorphosis leads to juveniles with smaller size correlated with low survival and locomotor performance (Székely et al., 2020). Pond drying may also lead to the loss of the capacity to respond to desiccation following decreased food availability (Enriquez-Urzelai et al., 2013), liver damage with upregulation of DIO2 and $\mathrm{TR} \alpha$ transcript levels while there is a decrease of $\operatorname{TR} \beta$ (Chen et al., 2021), or increased oxidative damage during metamorphosis (Petrović et al., 2021).

$\mathrm{TH}$ and GC level variations underlie differences in the timing of metamorphosis. In response to pond drying, western spadefoot toad and New Mexico spadefoot toad Spea multiplicata that have long larval periods and large size at metamorphosis, accelerate metamorphosis and elevate whole-body content of $\mathrm{TH}$ and corticosterone (Kulkarni et al., 2017). In contrast, in Couch's spadefoot toad Scaphiopus couchii that has a short larval period, whole-body $\mathrm{TH}$ and corticosterone content are high during metamorphosis and weakly affected by pond drying. Thus, species exhibiting less plasticity will be more sensitive to environmental changes. The $\mathrm{TH}$ and $\mathrm{CS}$ level variations to accelerate metamorphosis during habitat desiccation may originate from elevated CRH (Denver, 1997). CRH can be a transducer of environmental stimuli to modulate the rate of metamorphosis via the endocrine response. Interestingly, $\mathrm{CRH}$ has also been shown to control the term of pregnancy in mammals. Maternal plasma $\mathrm{CRH}$ concentrations are elevated early in pregnancy in those patients destined to deliver preterm, and are lower in patients destined to deliver post-dates (Challis and Hooper, 1989; McLean et al., 1995).

\section{Climate Changes and Terrestrial Biodiversity}

Temperature increase alters avian phenotypes such as advanced reproduction, migration schedules and individual appearance. Bird ability to maintain a stable body temperature in a wide range of thermal environments is regulated via endocrine pathways including TH and with a lesser extent CS (Ruuskanen et al., 2021). The knowledge on endocrine regulation of thermogenesis concerns mainly poultry, but poorly describe for environmental temperature variation. Offspring development are dependent of females via hormones deposited in eggs. Ambient temperature changes affect the hormone levels in the yolk including $\mathrm{TH}$ and CS. More specifically, $\mathrm{T}_{4}$ levels were negatively correlated with ambient temperature in great tits Parus major (Ruuskanen et al., 2016). However, in wild pied flycatchers Ficedula hypoleuca, there is no evidence for context-dependent effects of prenatal $\mathrm{TH}$ related to postnatal temperature on growth, survival, and plasma $\mathrm{TH}$ levels (Hsu et al., 2020), suggesting species differences or unknown confounding effects.

In reptiles and turtles, temperature effect on $\mathrm{TH}$ and GC plasma levels is controversial being either absent, positive or negative. Highlighting only a few examples, in the alligator lizards Elgaria coerulea and Elgaria multicarinata, corticosterone levels increase with temperature (Telemeco and Addis, 2014) and in the South-American tegu lizard Salvator merianae, $\mathrm{T}_{3}, \mathrm{~T}_{4}$, and corticosterone levels show a positive relationship with body temperature (Zena et al., 2020). Similar correlation between body temperature and plasma corticosterone is observed in the eastern fence lizards Sceloporus undulatus, under laboratory conditions, but not in the field (Racic et al., 2020). In contrast, in the common lizard Zootoca vivipara, baseline corticosterone levels decrease with increasing thermal conditions (Dupoué et al., 2018).

In mammals, we will only highlight two of the numerous examples. First, the transition between late gestation and early lactation is a developmental window sensitive to warming. Dairy cows experience stress due to the high energy and nutrient requirements of the fetus and the mammary gland. In early lactation, the decline of $\mathrm{TH}$ levels is more pronounced in cow maintained at $28^{\circ} \mathrm{C}$ compared to the one maintained at $15^{\circ} \mathrm{C}$ (Weitzel et al., 2017). The second example is an Artic mammal, which has highly evolved to these extreme environments and its capacity to adapt to this change may be limited. The polar bear is emblematic to this environment. It was shown that CS binding capacity of plasma CS binding globulin increases in polar bears as a consequence of climate warming (Boonstra et al., 2020). Evidence is still lacking to have a complete view of the interactions between $\mathrm{GC}$ and $\mathrm{TH}$ in response to global warming. 


\section{Endocrine Disruptors Thyroid Function Disruption}

As previously mentioned, TH orchestrates metamorphosis, brain development, and metabolism representing a potential target for endocrine disruptor chemicals/compounds (EDC). Although the molecular mechanisms for $\mathrm{TH}$ disruption is still unknown for most of the EDC, several affect TH synthesis, transport or metabolism and downstream effects (Thambirajah et al., 2019). One of the main concerns is disruption during early neurogenesis, which may affect several $\mathrm{TH}$ actions such as proliferation, differentiation, migration, synaptogenesis and myelination in the developing nervous system (Préau et al., 2015).

Because anuran metamorphosis is strictly dependent on $\mathrm{TH}$, amphibians represent sensitive models for the detection and mechanistic elucidation of $\mathrm{TH}$ disrupting activities (thyroid histology, metamorphosis progression). EDC impact wild anurans and contribute to population declines. Some pesticides and biocides may interfere with $\mathrm{TH}$ signaling during nervous system development (Leemans et al., 2019; Trudeau et al., 2020) or metamorphosis timing (Orton and Tyler, 2015). Last but not least, exposition of Xenopus tadpoles to the benzo[a]pyrene leads to delayed metamorphosis and sexual maturity with transgenerational disruption of metabolism and population decline (Usal et al., 2021).

In zebrafish, exposure during the 7 first days of development to 25 known TH disrupting compounds leads to morphological defects and variations of transcripts involved in the HPT axis (Spaan et al., 2019). In another teleost fish, the metamorphosing convict surgeonfish Acanthurus triostegus, high doses of the pesticide chlorpyrifos induce defects by decreasing TH levels impacting olfactory, visual and mechano-sensory structure development (Besson et al., 2020). Interestingly, similar phenotypes were observed following temperature increase, highlighting the profound threat anthropogenic stressors pose to fish communities. To highlight the EDC mode of action, liver transcriptomic responses in yellow perch Perca flavescens population show variation of genes transcripts related to reproduction, retinol, iron, $\mathrm{TH}$, oxidative stress, lipid metabolism, and immune functions between strongly impacted population vs. less impacted groups (Defo et al., 2018).

In birds as in teleost fishes and amphibians, because GC regulate metabolism, ability to modulate corticosterone in response to stressor is essential to face a wide array of environmental challenges. EDC contamination was shown to impair this GC role. Methylmercury exposure reduces stressinduced GC response in zebra finches, Taeniogypia guttata (Moore et al., 2014). TH function is also EDC target. The rural nestling peregrine falcon Falco peregrinus has significantly lower circulating concentrations of $\mathrm{TH}$ compared to urban nestlings where flame retardants are environmental contaminants that accumulate in predatory birds (Fernie et al., 2017).

EDC also affect TH signaling in mammals. Considering the large amount of recent data available, only a few examples will be given here. In mice, exposure to the flame-retardant, tetrabromo bisphenol A, modulates hypothalamic set-points controlling metabolic responses by targeting TR regulation of trh and mc4r (Decherf et al., 2010). In the polar bear Ursus maritimus, an heavily polluted organism for which some EDC are banned for decades (Routti et al., 2019), some EDC, such as organochlorine and perfluoroalkyl, are negatively correlated with plasma TH levels (Bourgeon et al., 2017). In wild chimpanzees, contamination by polluted drinking waters containing pesticides (Krief et al., 2017) and bisphenols (Krief et al., 2020) has been reported, and the water samples exhibit TH disrupting activities (Spirhanzlova et al., 2019). Experimental exposure of Xenopus laevis tadpoles to a mixture of 15 chemicals at concentrations reported in human amniotic fluid induces variation of behavior, of TH-responsive gene expression and of nervous system development (Fini et al., 2017). Considering the conservation of TH function across vertebrates, one may speculate on such impacts of amniotic fluid chemicals on human fetal brain development.

Environmental and health concerns remain particularly challenging when addressing thyroid hormone axis disruption. Only few chemicals have been tested, the number of test methods is limited and the thyroid system is complex. The development of specific chemical safety testing is required (Browne et al., 2020) with special attention to neurological development (Gilbert et al., 2020; Kortenkamp et al., 2020; O'Shaughnessy and Gilbert, 2020). Attention is also paid to break down the wall between mammalian and non-mammalian vertebrate regulatory testing (Couderq et al., 2020; Holbech et al., 2020). In addition to phenotypic or histological end-points, the use of molecular assays (transcripts, proteins or metabolites) will be more sensitive and most of all will allow detection before adverse effects occur (Fini et al., 2007; Kulkarni and Buchholz, 2013). Development of non-destructive (without euthanasia) biomarkers that provide causal link between the presence of a chemical and an ecological effect are also needed to allow the study of vulnerable populations.

\section{Corticosteroid Function Disruption}

The adrenal has been neglected in endocrine disruption regulatory testing strategy while the negative consequences of adrenocortical dysfunction during development have been recognized (Hinson and Raven, 2006; Harvey, 2016). Upstream of the biological effect, an activity mimicking that of GC was measured in surface waters (Schriks et al., 2013). Hydrocortisone was detected but could not explain a significant fraction of the observed GR activity.

GC synthesis pathway is also a target. Different environmental toxicants, including phthalate esters together with bisphenols and their analogs pose deleterious effects on the biosynthesis of GC in vitro (Ahmad et al., 2017; Verma et al., 2018). These observations were confirmed in vivo using nitrate, a major anthropogenic contaminant in the FW environment. In three-spined stickleback Gasterosteus aculeatus L., dissolved inorganic N directly exerts a disruptive influence on the function of the stress axis and GC levels, supporting concerns that nitrate is an EDC (Pottinger, 2017). GC disruption was linked to adverse effect in zebrafish exposed to methylparaben, widely used as antimicrobial preservative. In addition to increase in 
cortisol levels, animals show alteration of heart rate and hatching percentage as well as signs of anxiety-like behavior (Luzeena Raja et al., 2019).

Finally, because persistent organic pollutants can interact with GR, EDC mixtures were screened for GR translocation and GR transactivation in an in vitro assay (Wilson et al., 2016). EDC mixtures did not induce GR translocation in nucleus nor produce an agonist response in the GR transcriptional assay. However, in the presence of cortisol, some chemicals were found to decrease GR transcriptional activity.

\section{Endocrine Disruptor Chemicals/Compounds and Climate Change: A Worst Combination}

Climate change and exposure to EDCs are currently two of the most serious anthropogenic threats to biodiversity and ecosystems. Moreover, the ecological threats posed by EDC are further exacerbated by changing environmental conditions such as temperature, pond drying, food restriction, $\mathrm{pH}$ and ultraviolet radiation.

In aquatic environment, global warming may lead to temperature increase associated with either salinity increase due to evaporation or salinity decrease due to ice melting. One study addresses the combinatorial effect of temperature, salinity and diuron, an herbicide and antifouling agent with EDC property (Moreira et al., 2018). Combinatorial treatment of juveniles of the estuarine fish, the inland silverside Menidia beryllina, affects growth and hormonal levels. $\mathrm{T}_{3}$ increases in all of them, while $\mathrm{T}_{4}$ increases at low temperature and low salinity and decreases at low temperature and high salinity, in agreement with DIO2 expression. EDC, acidification and other contaminants can also perturb smolt development, resulting in poor survival after salinity increase (Björnsson et al., 2011). In the San Francisco Bay, the rainbow trout experiences warmer waters and saltwater intrusion (Giroux and Schlenk, 2021) leading to fry decrease in survival associated with $\mathrm{TH}$ increase. Our last example in teleost fishes highlights the interaction between temperature and perchlorate, a wellknown thyroid disruptor (Lee et al., 2014). Overall, the results suggest that perchlorate affects thyroid function and reproduction, and these adverse effects are worsened under high temperature.

As previously described in amphibians, a rapid transition into the juvenile stage is beneficial in stress conditions. Pond desiccation is associated to a decrease in dissolved oxygen and an increase in nitrogen levels for which anthropogenic sources such as chemical fertilizers can be heavily suspected. Ammonium nitrate or hypoxic conditions leads to survival decrease of the Natterjack toad Bufo calamita tadpoles (Ortiz-Santaliestra and Marco, 2015). When both stressors were combined, the lethal effects were additive and include malformations. Global warming lead also to predator-prey relationship modifications decreasing survival rates of tadpoles (Jara et al., 2019). In addition, the Bullfrog sensitivity to temperature leads to corticosterone hormonal changes that correlate with immunosuppression (Lima et al., 2020) and increases sensitivity to emerging infectious diseases in the concept of OneHealth. Urodela amphibians are also affected. Compared to a single exposure, Arizona tiger salamander larvae subjected to both temperature increase and perchlorate treatment further decrease their rate of development. These cotreated salamander larvae also present a significant smaller body mass and worse body condition.

Finally, Artic biodiversity is concerned by this double threat. EDC were measured in Arctic marine mammals and seabirds. The most pronounced relationships with endocrine function have been reported with the thyroid hormone system, the sex steroid hormones and cortisol (Jenssen, 2006). Because these endocrine systems are essential for completing life cycles and enabling animals to respond adequately to environmental stress, EDC may interfere with adaptations to increased stress situations.

\section{CONCLUSION}

We have highlighted the roles of $\mathrm{TH}$ - and CS-regulated developmental transitions in the innovation, adaptation and plasticity of life cycles in vertebrates. In one of his review, Buchholz discusses the similarities between birth in mammals and metamorphosis in frog with a focus on their regulation by $\mathrm{TH}$ and GC (Buchholz, 2015). He reminds us that "both frogs and mammals undergo a life history transition from aquatic (water and amniotic fluid) to terrestrial habitat," involving for the most striking examples, air-breathing thanks to lung maturation and maturation of the intestine to cope with the transition to a new food source. Similar $\mathrm{TH}$ and CS concentration profiles are observed in certain birds and reptiles at hatching and during molting, as well as in certain teleost fishes at hatching and during larval metamorphosis and smoltification (Wada, 2008). The multiple cross-talks between HPT and HPA/HPI axes represent critical mechanisms by which vertebrates modulate their perinatal/postembryonic development as well as their responses to a changing environment (Figure 4).

The exposome includes stressors with, for some, potential mortality risk by their long-term effects. Vertebrate respond to the risk/benefit trade-off by modulating the production of hormones by the stress and thyroid neuroendocrine axes. In this context, global warming leads to increases in average temperature and temperature variability. Considered as a threat for biodiversity (Radchuk et al., 2019), global warming is a well-known reprotoxicity risk (Parisi and Guerriero, 2019). However, the properties of TH and CS suggest their fundamental roles in thermal acclimation (de Bruijn and Romero, 2018), and evolution of ectothermy/endothermy (Little, 2021). Changes in hormone sensitivity at warm temperatures could mean that increasing temperatures will reduce the capacity of animals to regulate their physiologies to match demands. Aquatic and terrestrial environments are also increasingly contaminated by anthropogenic sources. The contaminants include pharmaceuticals, personal care products, and industrial and agricultural chemicals. Many of these chemicals have the potential to disrupt endocrine function that may lead to disease or 
foundations to disease later in life as well as disease transmission to descendants (Gore et al., 2015). The adverse effects including metabolic diseases, decreased capacity of reproduction, hormone-sensitive cancers, thyroid disorders, and neurological defects may contribute to population decline. The difficulties tie in the circumstances EDC act, including nonmonotonic dose-responses, low-dose effects, and developmental vulnerability. Possible roles for the neuroendocrine stress axis in mediating these developmental responses requires further investigation.

\section{AUTHOR CONTRIBUTIONS}

All Authors contribute equally to the redaction of the review.

\section{REFERENCES}

Adams, A., and Bull, A. (1949). The effects of antithyroid drugs of chick embryos. Anat. Rec. 104, 421-443.

Aerts, J. (2018). Quantification of a glucocorticoid profile in non-pooled samples is pivotal in stress research across vertebrates. Front. Endocrinol. (Lausanne) 9:635. doi: 10.3389/fendo.2018.00635

Ahmad, S., Khan, M. F., Parvez, S., Akhtar, M., and Raisuddin, S. (2017). Molecular docking reveals the potential of phthalate esters to inhibit the enzymes of the glucocorticoid biosynthesis pathway. J. Appl. Toxicol. 37, 265-277. doi: 10.1002/ jat.3355

Alexander, D. P., Britton, H. G., James, V. H., Nixon, D. A., Parker, R. A., Wintour, E. M., et al. (1968). Steroid secretion by the adrenal gland of foetal and neonatal sheep. J. Endocrinol. 40, 1-13. doi: 10.1677/joe.0.0400001

Alfonso, S., Gesto, M., and Sadoul, B. (2020). Temperature increase and its effects on fish stress physiology in the context of global warming. J. Fish. Biol. 98, 1496-1508.

Aluru, N., and Vijayan, M. M. (2008). Molecular characterization, tissue-specific expression, and regulation of melanocortin 2 receptor in rainbow trout. Endocrinology 149, 4577-4588. doi: 10.1210/en.2008-0435

Alves, R. N., Cardoso, J. C. R., Harboe, T., Martins, R. S. T., Manchado, M., Norberg, B., et al. (2017). Duplication of Dio3 genes in teleost fish and their divergent expression in skin during flatfish metamorphosis. Gen. Comp. Endocrinol. 246, 279-293. doi: 10.1016/j.ygcen.2017.01.002

Arai, M., Assil, I., and Abou-Samra, A. (2001). Characterization of three corticotropin-releasing factor receptors in catfish: a novel third receptor is predominantly expressed in pituitary and urophysis. Endocrinology 142, 446454. doi: 10.1210/en.142.1.446

Arjona, F. J., Vargas-Chacoff, L., Martin del Rio, M. P., Flik, G., Mancera, J. M., and Klaren, P. H. M. (2011). Effects of cortisol and thyroid hormone on periphearl outer ring deiodination and osmoregulatory parameters in the Senegalese sole (Solea senegalensis). J. Endocrinol. 208, 323-330.

Bagamasbad, P. D., Bonett, R. M., Sachs, L., Buisine, N., Raj, S., Knoedler, J. R., et al. (2015). Deciphering the regulatory logic of an ancient, ultraconserved nuclear receptor enhancer module. Mol. Endocrinol. 29, 856-872. doi: 10.1210/ me.2014- 1349

Baggerman, B. (1963). The effect of TSH and antithyroid substances on salinity preference and thyroid activity in juvenile pacific salmon. Can. J. Zool. 41, 307-319.

Baker, M. E., and Katsu, Y. (2019). Evolution of the mineralocorticoid receptor. Vitam. Horm. 109, 17-36. doi: 10.1016/bs.vh.2018.10.009

Balaban, M., and Hill, J. (1971). Effects of thyroxine level and temperature manipulations upon the hatching of chick embryos (Gallus domesticus). Dev. Psychobiol. 4, 17-35. doi: 10.1002/dev.420040103

Ballard, P. L., Hovey, M. L., and Gonzales, L. K. (1984). Thyroid hormone stimulation of phosphatidylcholine synthesis in cultured fetal rabbit lung lung. since glucocorticoids stimulate surfactant synthesis drome in premature

\section{FUNDING}

LS work was supported by “ERGO," a European Union's Horizon 2020 Research and Innovation program, under grant agreement no. 825753. The authors are supported by the "Centre National de la Recherche Scientifique" and the "Muséum National d'Histoire Naturelle."

\section{ACKNOWLEDGMENTS}

We thank Robert Denver (Department of Molecular, Cellular and Developmental Biology and Department of Ecology and Evolutionary Biology, University of Michigan, Ann Arbor, United States) for critical reading of the manuscript, and Dr. A. Virmani for proofreading the manuscript.

infants, we also examined the choline was determined in organ cultures of rabbit lun. J. Clin. Invest. 74, 898-905.

Barnes, R. J., Comline, R. S., and Silver, M. (1977). The effects of bilateral adrenalectomy or hypophysectomy of the foetal lamb in utero. J. Physiol. 264, 429-447. doi: 10.1113/jphysiol.1977.sp0 11676

Barton, B. A., Schreck, C. B., Ewing, R. D., Hemmingsen, A. R., and Patiño, R. (1985). Changes in plasma cortisol during stress and smoltification in Coho Salmon, Oncorhynchus kisutch. Gen. Comp. Endocrinol. 59, 468-471. doi: 10. 1016/0016-6480(85)90406-X

Beldade, R., Blandin, A., O’Donnell, R., and Mills, S. (2017). Cascading effects of thermally-induced anemone bleaching on associated anemonefish hormonal stress response and reproduction. Nat. Commun. 8:716. doi: 10.1038/s41467017-00565-w

Bernier, N. J., Flik, G., and Klaren, P. H. M. (2009). Regulation and contribution of corticotropic, melanotropic and thyrotropic axes to the stress response in fishes. Fish Physiol. 28, 235-311. doi: 10.1016/S1546-5098(09)2 8006-X

Berry, X., Banu, X., and Larsen, X. (1991). Type I iodothyronine deiodinase is a selenocysteine-containing enzyme. Nature 349, 438-440.

Besson, M., Feeney, W., Moniz, I., FRançois, L., Brooker, R., Holzer, G., et al. (2020). Anthropogenic stressors impact fish sensory development and survival via thyroid disruption. Nat. Commun. 11:3614. doi: 10.1038/s41467-02017450-8

Bianco, A. C., Salvatore, D., Gereben, B., Berry, M. J., and Larsen, P. R. (2002). Biochemistry, cellular and molecular biology, and physiological roles of the iodothyronine selenodeiodinases. Endocr. Rev. 23, 38-89. doi: 10.1210/edrv.23. 1.0455

Bidaud, I., Lory, P., Nicolas, P., Bulant, M., and Ladram, A. (2002). Characterization and functional expression of cDNAs encoding thyrotropinreleasing hormone receptor from Xenopus laevis: Identification of a novel subtype of thyrotropin-releasing hormone receptor. Eur. J. Biochem. 269, 45664576. doi: 10.1046/j.1432-1033.2002.03152.x

Bilesimo, P., Jolivet, P., Alfama, G., Buisine, N., Le Mevel, S., Havis, E., et al. (2011). Specific histone lysine 4 methylation patterns define TR-binding capacity and differentiate direct T3 responses. Mol. Endocrinol. 25, 225-237. doi: 10.1210/ me.2010-0269

Bishop, C. D., Erezyilmaz, D. F., Flatt, T., Georgiou, C. D., Hadfield, M. G., Heyland, A., et al. (2006). What is metamorphosis? Integr. Comp. Biol. 46, 655-661. doi: 10.1093/icb/icl004

Björnsson, B. T., Einarsdottir, I. E., and Power, D. (2012). Is salmon smoltification an example of vertebrate metamorphosis? Lessons learnt from work on flatfish larval development. Aquaculture 362-363, 264-272. doi: 10.1016/j.aquaculture. 2011.03.002

Björnsson, B. T., Stefansson, S. O., and McCormick, S. D. (2011). Environmental endocrinology of salmon smoltification. Gen. Comp. Endocrinol. 170, 290-298. doi: 10.1016/j.ygcen.2010.07.003 
Boeuf, G. (1993). "Salmonid smolting: a pre-adaptation to the oceanic environment," in Fish Ecophysiology, eds J. Rankin and F. Jensen (London: Chapman Press), 105-135.

Bonett, R. M., Hu, F., Bagamasbad, P., and Denver, R. J. (2009). Stressor and glucocorticoid-dependent induction of the immediate early gene krüppel-like factor 9: implications for neural development and plasticity. Endocrinology 150, 1757-1765. doi: 10.1210/en.2008-1441

Bonett, R., Hoopfer, E., and Denver, R. (2010). Molecular mechanisms of corticosteroid synergy with thyroid hormone during tadpole metamorphosis. Gen. Comp. Endocrinol. 168, 209-219.

Boonstra, R., Bodner, K., Bosson, C., Elehanty, B., Richardson, E., Lunn, N., et al. (2020). The stress of arctic warming on polar bears. Golb. Chang. Biol. 26, 4197-4214.

Borges, M., Labourene, J., and Ingbar, S. H. (1980). Changes in hepatic iodothyronine metabolism during ontogeny of the chick embryo. Endocrinology 107, 1751-1761. doi: 10.1210/endo-107-6-1751

Bosc, M. (1973). Modification de la durée de gestation de la truie après administration d'ACTH aux foestus. Comptes Rendus Hebd. Des Seances L Acad. Des Sci. Ser. D 276, 3183-3186.

Bourgeon, S., Riemer, A. K., Tartu, S., Aars, J., Polder, A., Jenssen, B. M., et al. (2017). Potentiation of ecological factors on the disruption of thyroid hormones by organo-halogenated contaminants in female polar bears (Ursus maritimus) from the Barents Sea. Environ. Res. 158, 94-104. doi: 10.1016/j.envres.2017. 05.034

Brooks, A., Sweeney, G., and Old, R. (1989). Structure and functional expression of a cloned Xenopus thyroid hormone receptor. Nucleic Recept. Res 17, 9395-9405.

Brown, C., Urbinati, E., Zhang, W., Brown, S., and McComb-Kobza, M. (2014). Maternal thyroid and glucocorticoid hormone interactions in larval fish development, and their applications in aquaculture. Rev. Fish. Sci. Aquac. 22, 207-220.

Browne, P., Van Der Wal, L., and Gourmelon, A. (2020). OECD approaches and considerations for regulatory evaluation of endocrine disruptors. Mol. Cell. Endocrinol. 504:110675. doi: 10.1016/j.mce.2019.110675

Buchholz, D. R. (2015). More similar than you think: frog metamorphosis as a model of human perinatal endocrinology. Dev. Biol. 408, 188-195. doi: 10.1016/ j.ydbio.2015.02.018

Buchholz, D. R. (2017). Xenopus metamorphosis as a model to study thyroid hormone receptor function during vertebrate developmental transitions. Mol. Cell. Endocrinol. 459, 64-70. doi: 10.1016/j.mce.2017.03.020

Buchholz, D. R., and Shi, Y. B. (2018). Dual function model revised by thyroid hormone receptor alpha knockout frogs. Gen. Comp. Endocrinol. 265, 214-218. doi: 10.1016/j.ygcen.2018.04.020

Buchholz, D. R., Hsia, S.-C. V., Fu, L., and Shi, Y.-B. (2003). A dominant-negative thyroid hormone receptor blocks amphibian metamorphosis by retaining corepressors at target genes. Mol. Cell. Biol. 23, 6750-6758. doi: 10.1128/mcb. 23.19.6750-6758.2003

Buchholz, D. R., Tomita, A., Fu, L., Paul, B. D., and Shi, Y.-B. (2004). Transgenic analysis reveals that thyroid hormone receptor is sufficient to mediate the thyroid hormone signal in frog metamorphosis. Mol. Cell. Biol. 24, 9026-9037. doi: $10.1128 / \mathrm{mcb} .24 .20 .9026-9037.2004$

Bury, N. R. (2017). The evolution, structure and function of the ray finned fish (Actinopterygii) glucocorticoid receptors. Gen. Comp. Endocrinol. 251, 4-11. doi: 10.1016/j.ygcen.2016.06.030

Campinho, M. A., Galay-Burgos, M., Sweeney, G. E., and Power, D. M. (2010). Coordination of deiodinase and thyroid hormone receptor expression during the larval to juvenile transition in sea bream (Sparus aurata, Linnaeus). Gen. Comp. Endocrinol. 165, 181-194. doi: 10.1016/j.ygcen.2009.06.020

Campinho, M. A., Silva, N., Martins, G. G., Anjos, L., Florindo, C., Roman-Padilla, J., et al. (2018). A thyroid hormone regulated asymmetric responsive centre is correlated with eye migration during flatfish metamorphosis. Sci. Rep. 8, 1-12. doi: 10.1038/s41598-018-29957-8

Cardoso, J. C. R., Bergqvist, C. A., Félix, R. C., and Larhammar, D. (2016). Corticotropin-releasing hormone family evolution: five ancestral genes remain in some lineages. J. Mol. Endocrinol. 57, 73-86. doi: 10.1530/JME-16-0051

Cardoso, J. C. R., Laiz-Carrion, R., Louro, B., Silva, N., Canario, A. V. M., Mancera, J. M., et al. (2011). Divergence of duplicate POMC genes in gilthead sea bream
Sparus auratus. Gen. Comp. Endocrinol. 173, 396-404. doi: 10.1016/j.ygcen. 2010.12.001

Carsia, R. V., Morin, M. E., Rosen, H., and Weber, H. (1987). Ontogenic corticosteroidogenesis of the domestic fowl: response of isolated adrenocortical cells. Proc. Soc. Exp. Biol. Med. 184, 436-445.

Casey, B. M., Dashe, J. S., Wells, C. E., McIntire, D. D., Byrd, W., Leveno, K. J., et al. (2005). Subclinical hypothyroidism and pregnancy outcomes. Obstet. Gynecol. 105, 239-245. doi: 10.1097/01.AOG.0000152345.99421.22

Castañeda-Cortés, D. C., Arias Padilla, L. F., Langlois, V. S., Somoza, G. M., and Fernandino, J. I. (2019). The central nervous system acts as a transducer of stress-induced masculinization through corticotropin-releasing hormone B. Development (Cambridge) 146:dev172866.

Castañeda-Cortés, D. C., Zhang, J., Boan, A. F., Langlois, V. S., and Fernandino, J. I. (2020). High temperature stress response is not sexually dimorphic at the whole-body level and is dependent on androgens to induce sex reversal. Gen. Comp. Endocrinol. 299:113605.

Challis, J. R. G., and Hooper, S. (1989). Birth: outcome of a positive cascade. Baillieres Clin. Endocrinol. Metab. 3, 781-793. doi: 10.1016/S0950-351X(89) 80053-9

Chan, E., Falconer, J., Madsen, G., Rice, K., Webster, E., Chrousos, G., et al. (1998). A corticotropin-releasing hromone type I receptor antagonist delays parturition in sheep. Endocrinology 139, 3357-3360.

Chen, X., Ren, C., Teng, Y., Shen, Y., Wu, M., Xiao, H., et al. (2021). Effects of temperature on growth, development and the leptin signaling pathway of Bufo gargarizans. J. Therm. Biol. 96:102822. doi: 10.1016/j.jtherbio.2020.102822

Chester-Jones, I. (1987). "Structure of the adrenal and interrenal glands", in Fundamentals of Comparative Vertebrate Endocrinology, eds I. Chester-Jones, P. M. Ingleton, and J. G. Phillips (Boston, MA: Springer), 95-121. doi: 10.1007/ 978-1-4899-3617-2_3

Christensen, V. L. (1985). Supplemental thyroid hormones and hatchability of turkey eggs. Poult. Sci. 64, 2202-2210. doi: 10.3382/ps.0642202

Cone, R. D. (2006). Studies on the physiological functions of the melanocortin system. Endocr. Rev. 27, 736-749. doi: 10.1210/er.2006-0034

Cortés, R., Navarro, S., Agulleiro, M. J., Guillot, R., García-Herranz, V., Sánchez, E., et al. (2014). Evolution of the melanocortin system. Gen. Comp. Endocrinol. 209, 3-10. doi: 10.1016/j.ygcen.2014.04.005

Couderq, S., Leemans, M., and Fini, J. B. (2020). Testing for thyroid hormone disruptors, a review of non-mammalian in vivo models. Mol. Cell. Endocrinol. 508:110779. doi: 10.1016/j.mce.2020.110779

Coughlin, D. J., Forry, J. A., McGlinchey, S. M., Mitchell, J., Saporetti, K. A., and Stauffer, K. A. (2001). Thyroxine induces transitions in red muscle kinetics and steady swimming kinematics in rainbow trout (Oncorhynchus mykiss). J. Exp. Zool. 290, 115-124. doi: 10.1002/jez.1041

Dardente, H., Wood, S., Ebling, F., and Sáenz de Miera, C. (2019). An integrative view of mammalian seasonal neuroendocrinology. J. Neuroendocrinol. 31, 1-17. doi: $10.1111 /$ jne. 12729

Darras, V. M., and Van Herck, S. L. J. (2012). Iodothyronine deiodinase structure and function: from ascidians to humans. J. Endocrinol. 215, 189-206. doi: 10. 1530/JOE-12-0204

Darras, V. M., Kotanen, S. P., Geris, K. L., and Kühn, E. R. (1996). Plasma thyroid hormone levels and iodothyronine deiodinase activity following an acute glucocorticoid challenge in embryonic compared with posthatch chickens. Gen. Comp. Endocrinol. 104, 203-212. doi: 10.1006/gcen.1996.0163

Darras, V. M., Visser, T. J., Berghman, L. R., and Kühn, E. R. (1992). Ontogeny of type I and type III deiodinase activities in embryonic and posthatch chicks: relationship with changes in plasma triiodothyronine and growth hormone levels. Comp. Biochem. Physiol. Part A Physiol. 103, 131-136. doi: 10.1016/03009629(92)90252-L

Das, D., Ayromlooi, J., Bandyopadhyay, D., Bandyopadhyay, S., Neogi, A., and Steinberg, H. (1984). Potentiation of surfactant release in fetal lung by thyroid hormone action. J. Appl. Physiol. 56, 1621-1626.

Davey, J. C., Becker, K. B., Schneider, M. J., St. Germain, D. L., and Galton, V. A. (1995). Cloning of a cDNA for the type II iodothyronine deiodinase. J. Biol. Chem. 270, 26786-26789. doi: 10.1074/jbc.270.45.26786

de Bruijn, R., and Romero, L. M. (2018). The role of glucocorticoids in the vertebrate response to weather. Gen. Comp. Endocrinol. 269, 11-32. doi: 10. 1016/j.ygcen.2018.07.007 
De Groef, B., Grommen, S. V. H., and Darras, V. M. (2013). Hatching the cleidoic egg: the role of thyroid hormones. Front. Endocrinol. (Lausanne) 4:63. doi: 10.3389 /fendo. 2013.00063

De Groef, B., Van Der Geyten, S., Darras, V. M., and Kühn, E. R. (2006). Role of corticotropin-releasing hormone as a thyrotropin-releasing factor in nonmammalian vertebrates. Gen. Comp. Endocrinol. 146, 62-68. doi: 10.1016/j. ygcen.2005.10.014

de Jesus, E. G. T., Toledo, J. D., and Simpas, M. S. (1998). Thyroid hormones promote early metamorphosis in grouper (Epinephelus coioides) larvae. Gen. Comp. Endocrinol. 112, 10-16. doi: 10.1006/gcen.1998.7103

de Jesus, E. G., Inui, Y., and Hirano, T. (1990). Cortisol enhances the stimulating action of thyroid hormones on dorsal fin-ray resorption of flounder larvae in vitro. Gen. Comp. Endocrinol. 79, 167-173. doi: 10.1016/0016-6480(90) 90101-Q

de Jesus, E., Hirano, T., and Inui, Y. (1991). Changes in cortisol and thyroid hormone concentrations during early development and metamorphosis in the Japanese flounder, Paralichthys olivaceus. Gen. Comp. Endocrinol. 82, 369-376.

De Souza, F. S. J., Bumaschny, V. F., Low, M. J., and Rubinstein, M. (2005). Subfunctionalization of expression and peptide domains following the ancient duplication of the proopiomelanocortin gene in teleost fishes. Mol. Biol. Evol. 22, 2417-2427. doi: 10.1093/molbev/msi236

Decherf, S., Seugnet, I., Fini, J. B., Clerget-Froidevaux, M. S., and Demeneix, B. A. (2010). Disruption of thyroid hormone-dependent hypothalamic setpoints by environmental contaminants. Mol. Cell. Endocrinol. 323, 172-182. doi: 10.1016/j.mce.2010.04.010

Decuypere, E., Scanes, C., and Kühn, E. (1983). Effects of glucocorticoids on circulating concentrations of thyroxine (t4) and triiodothyronine $(\mathrm{t} 3)$ and on peripheral monodeiodination in pre- and post-hatching chicken. Horm. Metab. Res. 15, 233-236.

Defo, M. A., Douville, M., Giraudo, M., Brodeur, P., Boily, M., and Houde, M. (2018). RNA-sequencing to assess the health of wild yellow perch (Perca flavescens) populations from the St. Lawrence River, Canada. Environ. Pollut. 243, 1657-1668. doi: 10.1016/j.envpol.2018.09.133

Dehal, P., and Boore, J. L. (2005). Two rounds of whole genome duplication in the ancestral vertebrate. PLoS Biol. 3:e314. doi: 10.1371/journal.pbio.003 0314

Denver, R. (2009). "Endocrinology of complex life cycles: amphibians," in Hormones, Brain and Behavior, eds D. Pfaff, A. Arnold, A. Etgen, R. Rubin, and S. Fahrbach (Amsterdam: Elsevier), 707-744.

Denver, R. (2017). "Endocrinology of complex life cycles: amphibians," in Hormones, Brain and Behavior, eds D. Pfaff and J. Marian (Oxford: Academic Press), 145-148.

Denver, R. J. (1993). Acceleration of anuran amphibian metamorphosis by corticotropin-releasing hormone-like peptides. Gen. Comp. Endocrinol. 91, 38-51. doi: 10.1006/gcen.1993.1102

Denver, R. J. (1997). Environmental stress as a developmental cue: corticotropinreleasing hormone is a proximate mediator of adaptive phenotypic plasticity in amphibian metamorphosis. Horm. Behav. 31, 169-179. doi: 10.1006/hbeh.1997. 1400

Denver, R. J. (2021). Stress hormones mediate developmental plasticity in vertebrates with complex life cycles. Neurobiol. Stress 14:100301. doi: 10.1016/j. ynstr.2021.100301

Denver, R. J., Hu, F., Scanlan, T. S., and Furlow, J. D. (2009). Thyroid hormone receptor subtype specificity for hormone-dependent neurogenesis in Xenopus laevis. Dev. Biol. 326, 155-168. doi: 10.1016/j.ydbio.2008.11.005

Dimond, M.-T. (1954). The reactions of developing snapping turtles, Chelydra serpentina serpentina (Linné), to thiourea. J. Exp. Zool. 127, 93-117.

Dores, R. M., and Garcia, Y. (2015). Views on the co-evolution of the melanocortin2 receptor, MRAPs, and the hypothalamus/pituitary/adrenal-interrenal axis. Mol. Cell. Endocrinol. 408, 12-22. doi: 10.1016/j.mce.2014.12.022

Dores, R. M., Londraville, R. L., Prokop, J., Davis, P., Dewey, N., and Lesinski, N. (2014). Molecular evolution of GPCRs: melanocortin/melanocortin receptors. J. Mol. Endocrinol. 52, T29-T42. doi: 10.1530/JME-14-0050

Dores, R., Lecaudé, S., Bauer, D., and Danielson, P. (2002). Analyzing the evolution of the opioid/orphanin gene family. Mass Spectrom. Rev. 21, 220-243. doi: 10.1002/mas.10029
Dubois, J., and Dussault, J. (1977). Ontogenesis of thyroid function in the neonatal rat. Thyroxine and triiodothyronine production rates. Endocrinology 101, 435-441.

Dupoué, A., Rutschmann, A., Le Galliard, J. F., Clobert, J., Blaimont, P., Sinervo, B., et al. (2018). Reduction in baseline corticosterone secretion correlates with climate warming and drying across wild lizard populations. J. Anim. Ecol. 87, 1331-1341. doi: 10.1111/1365-2656.12843

Eales, J., Morin, P., Tsang, P., and Hara, T. (1993). Thyroid hormone deiodination in brain, liver, gill, heart and msucle of Atlantic salmon (Salmo salar) during the photoperiodically-induced parr-smolt transformation. II. Outerand inner-ring 3,5,3'-triiodo-L-thyronine and 3,3',5'-triiodothyronine-L-thyro. Gen. Comp. Endocrinol. 90, 157-167.

Ebbesson, L. O. E., Nilsen, T. O., Helvik, J. V., Tronci, V., and Stefansson, S. O. (2011). Corticotropin-releasing factor neurogenesis during midlife development in salmon: genetic, environmental and thyroid hormone regulation. J. Neuroendocrinol. 23, 733-741. doi: 10.1111/j.1365-2826.2011. 02164.x

Einarsdóttir, I. E., Silva, N., Power, D. M., Smáradóttir, H., and Björnsson, B. T. (2006). Thyroid and pituitary gland development from hatching through metamorphosis of a teleost flatfish, the Atlantic halibut. Anat. Embryol. (Berl) 211, 47-60. doi: 10.1007/s00429-005-0055-Z

Enriquez-Urzelai, U., San Sebastián, O., Garriga, N., and Llorente, G. A. (2013). Food availability determines the response to pond desiccation in anuran tadpoles. Oecologia 173, 117-127. doi: 10.1007/s00442-013-2596-9

Faught, E., Aluru, N., and Vijayan, M. M. (2016). “The molecular stress response," in Biology of Stress in Fish - Fish Physiology, eds C. B. Schreck, L. Tort, A. P. Farrell, and C. J. Brauner (Amsterdam: Elsevier Inc), 113-166. doi: 10.1016/ B978-0-12-802728-8.00004-7

Fernie, K. J., Chabot, D., Champoux, L., Brimble, S., Alaee, M., Marteinson, S., et al. (2017). Spatiotemporal patterns and relationships among the diet, biochemistry, and exposure to flame retardants in an apex avian predator, the peregrine falcon. Environ. Res. 158, 43-53. doi: 10.1016/j.envres.2017.05.035

Filipsson, K., Bergman, E., Greenberg, L., Österling, M., Watz, J., and Erlandsson, A. (2020). Temperature and predator-mediated regulation of plasma cortisol and brain gene expression in juvenile brown trout (Salmo trutta). Front. Zool. 17:25. doi: 10.1186/s12983-020-00372-y

Fini, J. B., Mughal, B. B., Le Mével, S., Leemans, M., Lettmann, M., Spirhanzlova, P., et al. (2017). Human amniotic fluid contaminants alter thyroid hormone signalling and early brain development in Xenopus embryos. Sci. Rep. 7, 1-12. doi: $10.1038 /$ srep43786

Fini, J., Le Mevel, S., Turque, N., Palmier, K., Zalko, D., Cravedi, J., et al. (2007). An in vivo multiwell-based fluorescent screen for monitoring vertebrate thyroid hormone disruption. Env. Sci. Technol. 41, 5908-5914. doi: 10.1021/es0704129

Fleming, M. S., Maugars, G., Lafont, A.-G., Rancon, J., Fontaine, R., NourizadehLillabadi, R., et al. (2019). Functional divergence of thyrotropin beta-subunit paralogs gives new insights into salmon smoltification metamorphosis. Sci. Rep. 9:4561. doi: 10.1038/s41598-019-40019-5

Forhead, A. J., and Fowden, A. L. (2014). Thyroid hormones in fetal growth and prepartum maturation. J. Endocrinol. 221, R87-R103. doi: 10.1530/JOE-140025

Forhead, A. J., Curtis, K., Kaptein, E., Visser, T. J., and Fowden, A. L. (2006). Developmental control of iodothyronine deiodinases by cortisol in the ovine fetus and placenta near term. Endocrinology 147, 5988-5994. doi: 10.1210/en. 2006-0712

Forrest, D., Sjoberg, M., and Vennstrom, B. (1990). Contrasting developmental and tissue-specific expression of $\alpha$ and $\beta$ thyroid hormone receptor genes. EMBO J. 9, 1519-1528. doi: 10.1002/j.1460-2075.1990.tb08270.x

Fowden, A. L., and Forhead, A. J. (2009). Hormones as epigenetic signals in developmental programming. Exp. Physiol. 94, 607-625. doi: 10.1113/ expphysiol.2008.046359

Fowden, A. L., and Forhead, A. J. (2015). Glucocorticoids as regulatory signals during intrauterine development. Exp. Physiol. 100, 1477-1487. doi: 10.1113/ EP085212

Fowden, A. L., Valenzuela, O. A., Vaughan, O. R., Jellyman, J. K., and Forhead, A. J. (2016). Glucocorticoid programming of intrauterine development. Domest. Anim. Endocrinol. 56, S121-S132. doi: 10.1016/j.domaniend.2016.02.014 
Freire, R., Van Dort, S., and Rogers, L. J. (2006). Pre- and post-hatching effects of corticosterone treatment on behavior of the domestic chick. Horm. Behav. 49, 157-165. doi: 10.1016/j.yhbeh.2005.05.015

Frigerio, D., Moestl, E., and Kotrschal, K. (2001). Excreted metabolites of gonadal steroid hormones and corticosterone in greylag geese (Anser anser) from hatching to fledging. Gen. Comp. Endocrinol. 124, 246-255. doi: 10.1006/gcen. 2001.7706

Furlow, J. D., and Neff, E. S. (2006). A developmental switch induced by thyroid hormone: Xenopus laevis metamorphosis. Trends Endocrinol. Metab. 17, 40-47. doi: 10.1016/j.tem.2006.01.007

Galas, L., Raoult, E., Tonon, M. C., Okada, R., Jenks, B. G., Castaño, J. P., et al. (2009). TRH acts as a multifunctional hypophysiotropic factor in vertebrates. Gen. Comp. Endocrinol. 164, 40-50. doi: 10.1016/j.ygcen.2009.05.003

Galay-Burgos, M., Power, D. M., Llewellyn, L., and Sweeney, G. E. (2008). Thyroid hormone receptor expression during metamorphosis of Atlantic halibut (Hippoglossus hippoglossus). Mol. Cell. Endocrinol. 281, 56-63. doi: 10. 1016/j.mce.2007.10.009

Galton, V. (1989). The role of 3,5,3'-triiodothyronine in the physiological action of thyroxine in the premetamorphic tadpole. Endocrinol. Endocrinol. 124, 2427-2433.

Galton, V. (1990). Mechanisms underlying the acceleration of thyroid hormoneinduced tadpole metamorphosis by corticosterone. Endocrinology 127, 29973002. doi: 10.1210/endo-127-6-2997

Galton, V. A., and Hiebert, A. (1987). The ontogeny of the enzyme systems for the 5- and 5-deiodination of thyroid hormones in chick embryo liver. Endocrinology 120, 2604-2610. doi: 10.1210/endo-120-6-2604

Gilbert, M. E., O'Shaughnessy, K. L., and Axelstad, M. (2020). Regulation of thyroid-disrupting chemicals to protect the developing brain. Endocrinology (United States) 161, 1-17. doi: 10.1210/endocr/bqaa106

Gilbert, W. M., Eby-Wilkens, E., Plopper, C., Whitsett, J. A., and Tarantal, A. F. (2001). Fetal monkey surfactants after intra-amniotic or maternal administration of betamethasone and thyroid hormone. Obstet. Gynecol. 98, 466-470. doi: 10.1016/S0029-7844(01)01417-X

Gilmour, K. M. (2005). Mineralocorticoid receptors and hormones: fishing for answers. Endocrinology 146, 44-46. doi: 10.1210/en.2004-1390

Giroux, M., and Schlenk, D. (2021). The effects of temperature and salinity on the endocrinology in two life stages of juvenile rainbow/steelhead trout (Oncorhynchus mykiss). J. Fish. Biol. 99, 513-523. doi: 10.1111/jfb.14741

Glennemeier, K. A., and Denver, R. J. (2002). Developmental changes in interrenal responsiveness in anuran amphibians. Integr. Comp. Biol. 42, 565-573. doi: 10.1093/icb/42.3.565

Godart, M., Frau, C., Farhat, D., Giolito, M., Jamard, C., Le Nevé, C., et al. (2021). Murine intestinal stem cells are highly sensitive to modulation of the T3/TR $\alpha 1$-dependent pathway. Development 148:dev194357.

Gomez-Mestre, I., Kulkarni, S., and Buchholz, D. R. (2013). Mechanisms and consequences of developmental acceleration in tadpoles responding to pond drying. PLoS One 8:e84266. doi: 10.1371/journal.pone.00 84266

Gonzalez, L., Ballard, P., Ertzey, R., and Williams, M. (1986). Glucocorticoids and thyroid hormones stimulate biochemical and morphological differentiation of human fetal lung in organ culture. J. Clin. Endocrinol. Metab. 62, 678-691.

Gore, A., Chappell, V., Fenton, S., Flaws, J., Nadal, A., Prins, G., et al. (2015). Executive summary to EDC-2: the endocrine society's second scientific statement on endocrine-disrupting chemicals. Endocr. Rev. 36, 593-602. doi: 10.1210/er.2015-1093

Gorissen, M., and Flik, G. (2016). “The endocrinology of the stress response in fish: an adaptation-physiological view," in Biology of Stress In Fish: Fish Physiology, Vol. 35, eds C. Schreck, L. Tort, A. Farrell, and C. Brauner (London: Elsevier), 75-111.

Grimaldi, A., Buisine, N., Miller, T., Shi, Y. B., and Sachs, L. M. (2013). Mechanisms of thyroid hormone receptor action during development: lessons from amphibian studies. Biochim. Biophys. Acta Gen. Subj. 1830, 3882-3892. doi: 10.1016/j.bbagen.2012.04.020

Grone, B. P., and Maruska, K. P. (2015). Divergent evolution of two corticotropinreleasing hormone $(\mathrm{CRH})$ genes in teleost fishes. Front. Neurosci. 9:365. doi: $10.3389 /$ fnins.2015.00365

Grossowicz, N. (1946). Influence of thiourea on development of the chick embryo. Proc. Soc. Exp. Biol. Med. 63, 151-152.
Gudernatch, J. (1912). Feeding experiments on tadpoles. I. The influence of specific organs given as food on growth and differentiation. A contribution to the knowledge of organs with internal secretion. Arch. Entwicklungsmech. Org. 35, 457-483.

Guillemin, R., and Rosenberg, B. (1955). Humoral hypothalamic control of anterior pituitary: a study with combined tissue cultures. Endocrinology 57, 599-607.

Guillemin, R., Yamazaki, E., Gard, D. A., Jutisz, M., and Sakiz, E. (1963). In vitro secretion of thyrotropin (TSH): stimulation by a hypothalamic peptide (TRF). Endocrinology 73, 564-572. doi: 10.1210/endo-73-5-564

Guillemin, R., Yamazaki, E., Jutosz, M., and Sakiz, E. (1962). Présence dans un extrait de tissus hypothalamiques d'une substance stimulant la sécrétion de l'hormone hypophysaire thyréotrope (TSH). Première purification par filtration sur gel Sephadex. C. R. Acad. Sci. Paris 255, 1018-1020.

Haba, G., Nishigori, H., Tezuka, Y., Kagami, K., Sugiyama, T., and Nishigori, H. (2011). Effect of antithyroid drug on chick embryos during the last week of development: delayed hatching and decreased cerebellar acetylcholinesterase activity. J. Obstet. Gynaecol. Res. 37, 1549-1556. doi: 10.1111/j.1447-0756.2011. 01573.x

Haitina, T., Klovins, J., Andersson, J., Fredriksson, R., Lagerström, M. C., Larhammar, D., et al. (2004). Cloning, tissue distribution, pharmacology and three-dimensional modelling of melanocortin receptors 4 and 5 in rainbow trout suggest close evolutionary relationship of these subtypes. Biochem. J. 380, 475-486. doi: 10.1042/BJ20031934

Halliday, R., and Buttle, H. R. (1968). The effects of cortisone acetate on the length of the gestation period and the survival of foetal Scottish Blackface lambs. J. Endocrinol. 41, 447-448. doi: 10.1677/joe.0.0410447

Harada, M., Yoshinaga, T., Ojima, D., and Iwata, M. (2008). cDNA cloning and expression analysis of thyroid hormone receptor in the coho salmon Oncorhynchus kisutch during smoltification. Gen. Comp. Endocrinol. 155, 658667. doi: 10.1016/j.ygcen.2007.09.004

Harris, A., Fang, S., Prosky, J., Braverman, L., and Vagenakis, A. (1978). Decreased outer ring monodeiodination of thyroxine and reverse triiodothyronine in fetal and neonatal rats. Endocrinology 103, 2216-2222.

Harris, R. M., Dijkstra, P. D., and Hofmann, H. A. (2014). Complex structural and regulatory evolution of the pro-opiomelanocortin gene family. Gen. Comp. Endocrinol. 195, 107-115. doi: 10.1016/j.ygcen.2013.10.007

Harvey, P. (2016). Adrenocortical endocrine disruption. J. Steroid Biochem. Mol. Biol. 155, 199-206. doi: 10.1016/j.jsbmb.2014.10.009

Hayes, T., Chan, R., and Licht, P. (1993). Interactions of temperature and steroids on larval growth, development, and metamorphosis in a toad (Bufo boreas). J. Exp. Zool. 266, 206-215. doi: 10.1002/jez.1402660306

Hayward, L. S., Richardson, J. B., Grogan, M. N., and Wingfield, J. C. (2006). Sex differences in the organizational effects of corticosterone in the egg yolk of quail. Gen. Comp. Endocrinol. 146, 144-148. doi: 10.1016/j.ygcen.2005.10.016

Heijlen, M., Houbrechts, A. M., Bagci, E., Van Herck, S. L. J., Kersseboom, S., Esquerra, C. V., et al. (2014). Knockdown of type 3 iodothyronine deiodinase severely perturbs both embryonic and early larval development in zebrafish. Endocrinology 155, 1547-1559. doi: 10.1210/en.2013-1660

Helbing, C. C., Crump, K., Bailey, C. M., Kohno, S., Veldhoen, N., Bryan, T., et al. (2006). Isolation of the alligator (Alligator mississippiensis) thyroid hormone receptor $\alpha$ and $\beta$ transcripts and their responsiveness to thyroid stimulating hormone. Gen. Comp. Endocrinol. 149, 141-150. doi: 10.1016/j.ygcen.2006. 05.019

Henriksen, R., Rettenbacher, S., and Groothuis, T. G. G. (2013). Maternal corticosterone elevation during egg formation in chickens (Gallus gallus domesticus) influences offspring traits, partly via prenatal undernutrition. Gen. Comp. Endocrinol. 191, 83-91. doi: 10.1016/j.ygcen.2013.05.028

Hinson, J. P., and Raven, P. W. (2006). Effects of endocrine-disrupting chemicals on adrenal function. Best Pract. Res. Clin. Endocrinol. Metab. 20, 111-120. doi: 10.1016/j.beem.2005.09.006

Hoar, W. (1976). Smolt transformation: evolution, behaviour, and physiology. J. Fish. Res. Board Can. 33, 1234-1252.

Hoar, W. S. (1988). The physiology of smolting salmonids. Fish Physiol. 11, 275-343. doi: 10.1016/S1546-5098(08)60216-2

Holbech, H., Matthiessen, P., Hansen, M., Schüürmann, G., Knapen, D., Reuver, M., et al. (2020). ERGO: breaking down the wall between human health and environmental testing of endocrine disrupters. Int. J. Mol. Sci. 21:2954. doi: $10.3390 /$ ijms 21082954 
Holzer, G., Roux, N., and Laudet, V. (2017). Evolution of ligands, receptors and metabolizing enzymes of thyroid signaling. Mol. Cell. Endocrinol. 459, 5-13. doi: 10.1016/j.mce.2017.03.021

Hotta, Y., Aritaki, M., Ohta, K., Tagwa, M., and Tanaka, M. (2001a). Development of the digestive system and metamorphosis relating hormones in spotted halibut larvae and early juveniles. Nippon Suisan Gakkai. 67, 40-48.

Hotta, Y., Aritaki, M., Tagawa, M., and Tanaka, M. (2001b). Changes in tissue thyroid hormone levels of metamorphosing spotted halibut Verasper variegatus reared at different temperatures. Fish. Sci. 67, 1119-1124. doi: 10.1046/j.14442906.2001.00369.x

Hsu, B. Y., Dijkstra, C., Darras, V. M., de Vries, B., and Groothuis, T. G. G. (2017). Maternal thyroid hormones enhance hatching success but decrease nestling body mass in the rock pigeon (Columba livia). Gen. Comp. Endocrinol. 240, 174-181. doi: 10.1016/j.ygcen.2016.10.011

Hsu, B.-Y., Sarraude, T., Cossin-Sevrin, N., Crombecque, M., Stier, A., and Ruuskanen, S. (2020). Testing for context-dependent effects of prenatal thyroid hormones on offspring survival and physiology: an experimental temperature manipulation. Sci. Rep. 10:14563.

Hu, F., Knoedler, J. R., and Denver, R. J. (2016). A mechanism to enhance cellular responsivity to hormone action: krüppel-like factor 9 promotes thyroid hormone receptor- $\beta$ autoinduction during postembryonic brain development. Endocrinology 157, 1683-1693. doi: 10.1210/en.2015-1980

Hwang, J. I., Moon, M. J., Park, S., Kim, D. K., Cho, E. B., Ha, N., et al. (2013). Expansion of secretin-like $G$ protein-coupled receptors and their peptide ligands via local duplications before and after two rounds of whole-genome duplication. Mol. Biol. Evol. 30, 1119-1130. doi: 10.1093/molbev/mst031

Hylka, V. W., and Doneen, B. A. (1983). Ontogeny of embryonic chicken lung: Effects of pituitary gland, corticosterone, and other hormones upon pulmonary growth and synthesis of surfactant phospholipids. Gen. Comp. Endocrinol. 52, 108-120. doi: 10.1016/0016-6480(83)90163-6

Ikuta, K., Aida, K., Okumoto, N., and Hanyu, I. (1985). Effects of thyroxine and methyltestosterone on smoltification of masu salmon (Oncorhynchus masou). Aquaculture 45, 289-303. doi: 10.1016/0044-8486(85)90276-5

Inui, Y., and Miwa, S. (1985). Thyroid hormone induces metamorphosis of flounder larvae. Gen. Comp. Endocrinol. 60, 450-454. doi: 10.1016/00166480(85)90080-2

Inui, Y., and Miwa, S. (2012). "Metamorphosis of flatfish (pleuronectiformes)," in Metamorphosis In Fish, eds S. Dufour, K. Rousseau, and B. Kapoor (Saint Helier: Science Publishers), 107-153.

Irachi, S., Hall, D. J., Fleming, M. S., Maugars, G., Björnsson, B. T., Dufour, S., et al. (2021). Photoperiodic regulation of pituitary thyroid-stimulating hormone and brain deiodinase in Atlantic salmon. Mol. Cell. Endocrinol. 519:111056. doi: 10.1016/j.mce.2020.111056

Isorna, E., Obregon, M. J., Calvo, R. M., Vázquez, R., Pendón, C., Falcón, J., et al. (2009). Iodothyronine deiodinases and thyroid hormone receptors regulation during flatfish (Solea senegalensis) metamorphosis. J. Exp. Zool. Part B Mol. Dev. Evol. 312, 231-246. doi: 10.1002/jez.b.21285

Itoh, K., Watanabe, K., Wu, X., and Suzuki, T. (2010). Three members of the iodothyronine deiodinase family, dio1, dio2 and dio3, are expressed in spatially and temporally specific patterns during metamorphosis of the flounder Paralichthys olivaceus. Zoolog. Sci. 27, 574-580.

Iwata, M., Yamauchi, K., Nishioka, R., Lin, R., and Bern, H. (1990). Effects of thyroxine, growth hormone and cortisol on salinity preference of juvenile coho salmon (Oncorhynchus kisutch). Mar. Behav. Physiol. 17, 191-201.

Izaz, A., Pan, T., Wang, L., Zhang, H., Duan, S., Li, E., et al. (2021). Molecular cloning, characterization, and gene expression behavior of glucocorticoid and mineralocorticoid receptors from the Chinese alligator (Alligator sinensis). J. Exp. Zool. B Mol. Dev. Evol. 336, 50-72.

Izumo, S., and Mahdavi, V. (1988). Thyroid hormone receptor $\alpha$ isoforms generated by alternative splicing differentially activate myosin $\mathrm{HC}$ gene transcription. Nature 334, 539-542. doi: 10.1038/334539a0

Janczak, A. M., Braastad, B. O., and Bakken, M. (2006). Behavioural effects of embryonic exposure to corticosterone in chickens. Appl. Anim. Behav. Sci. 96, 69-82. doi: 10.1016/j.applanim.2005.04.020

Jara, F., Thurman, L., Montiglio, P., Sih, A., and Garcia, T. (2019). Warminginduced shifts in amphibian phenology and behavior lead to altered predatorprey dynamics. Oecologia 189, 803-813. doi: 10.1007/s00442-019-04360-w
Jaudet, G. J., and Hatey, J. L. (1984). Variations in aldosterone and corticosterone plasma levels during metamorphosis in Xenopus laevis tadpoles. Gen. Comp. Endocrinol. 56, 59-65. doi: 10.1016/0016-6480(84)90061-3

Jellyman, J. K., Fletcher, A. J. W., Fowden, A. L., and Giussani, D. A. (2020). Glucocorticoid maturation of fetal cardiovascular function. Trends Mol. Med. 26, 170-184. doi: 10.1016/j.molmed.2019.09.005

Jennings, D. H., Moore, M. C., Knapp, R., Matthews, L., and Orchinik, M. (2000). Plasma steroid-binding globulin mediation of differences in stress reactivity in alternative male phenotypes in tree lizards, Urosaurus ornatus. Gen. Comp. Endocrinol. 120, 289-299. doi: 10.1006/gcen.2000.7564

Jenssen, B. (2006). Endocrine-disrupting chemicals and climate change: A worstcase combination for arctic marine mammals and seabirds? Env. Heal. Perspect. 114 Suppl, 76-80. doi: 10.1289/ehp.8057

Jolivet-Jaudet, G., and Leloup-Hâtey, J. (1986). Corticosteroid binding in plasma of Xenopus laevis. Modifications during metamorphosis and growth. J. Steroid Biochem. 25, 343-350. doi: 10.1016/0022-4731(86)90245-1

Jones, I., Rogers, S. A., Kille, P., and Sweeney, G. E. (2002). Molecular cloning and expression of thyroid hormone receptor alpha during salmonid development. Gen. Comp. Endocrinol. 125, 226-235. doi: 10.1006/gcen.2001.7745

Kalliecharan, R., and Hall, B. K. (1974). A developmental study of the levels of progesterone, corticosterone, cortisol, and cortisone circulating in plasma of chick embryos. Gen. Comp. Endocrinol. 24, 364-372. doi: 10.1016/00166480(74)90149-X

Kanaho, Y. I., Endo, D., and Park, M. K. (2006). Molecular characterization of thyroid hormone receptors from the leopard gecko, and their differential expression in the skin. Zool. Sci. 23, 549-556. doi: 10.2108/zsj.23.549

Kiilerich, P., Kristiansen, K., and Madsen, S. S. (2007). Hormone receptors in gills of smolting Atlantic salmon, Salmo salar: expression of growth hormone, prolactin, mineralocorticoid and glucocorticoid receptors and $11 \beta$ hydroxysteroid dehydrogenase type 2. Gen. Comp. Endocrinol. 152, 295-303. doi: 10.1016/j.ygcen.2006.12.018

Kikuyama, S., Niki, K., and Mayumi, M. (1982). Retardation of thyroxineinduced metamorphosis by Amphenone B in toad tadpoles. Endocrinol Jpn. 29, 659-662.

Kingsbury, J., Emery, S., and Adams, A. (1955). Effects of thiourea on the adrenal glands of chick embryos. Endocrinology 56, 299-304.

Kloas, W., Reinecke, M., and Hanke, W. (1997). Stage-dependent changes in adrenal steroids and catecholamines during development in Xenopus laevis. Gen. Comp. Endocrinol. 108, 416-426. doi: 10.1006/gcen.1997.6998

Kobayashi, H. (1958). Effect of desoxycorticosterone acetate on metamorphosis induced by throxine in anuran tadpoles. Endocrinology 62, 371-377. doi: 10. 1210/endo-62-4-371

Kobayashi, Y., Chiba, H., Yamanome, T., Schiöth, H. B., and Takahashi, A. (2011). Melanocortin receptor subtypes in interrenal cells and corticotropic activity of $\alpha$-melanocyte-stimulating hormones in barfin flounder, Verasper moseri. Gen. Comp. Endocrinol. 170, 558-568. doi: 10.1016/j.ygcen.2010.11.019

Kortenkamp, A., Axelstad, M., Baig, A. H., Bergman, ^̊, Bornehag, C. G., Cenijn, P., et al. (2020). Removing critical gaps in chemical test methods by developing new assays for the identification of thyroid hormone system-disrupting chemicalsthe athena project. Int. J. Mol. Sci. 21:3123. doi: 10.3390/ijms21093123

Krain, L. P., and Denver, R. J. (2004). Developmental expression and hormonal regulation of glucocorticoid and thyroid hormone receptors during metamorphosis in Xenopus laevis. J. Endocrinol. 181, 91-104. doi: 10.1677/joe. 0.1810091

Krief, S., Berny, P., Gumisiriza, F., Gross, R., Demeneix, B., Fini, J. B., et al. (2017). Agricultural expansion as risk to endangered wildlife: pesticide exposure in wild chimpanzees and baboons displaying facial dysplasia. Sci. Total Environ. 598, 647-656. doi: 10.1016/j.scitotenv.2017.04.113

Krief, S., Inglesias-Gonzalez, A., Appenzeller, B., Okimat, J., Fini, J.-B., Demeneix, B., et al. (2020). Road impact in a protected area with rich biodiversity: the case of the Sebitoli road in Kibale National Park, Uganda. Env. Sci. Pollut. Res. Int. 27, 27914-27925. doi: 10.1007/s11356-020-09098-0

Kudo, H., Tsuneyoshi, Y., Nagae, M., Adachi, S., Yamauchi, K., Ueda, H., et al. (1994). Detection of thyroid hormone receptors in the olfactory system and brain of wild masu salmon, Oncorhynchus masou (Brevoort), during smolting by in vitro autoradiography. Aquac. Res. 25, 171-181. doi: 10.1111/are.1994.25. s2.171 
Kulkarni, S. S., and Buchholz, D. R. (2012). Beyond synergy: Corticosterone and thyroid hormone have numerous interaction effects on gene regulation in Xenopus tropicalis tadpoles. Endocrinology 153, 5309-5324. doi: 10.1210/en. 2012-1432

Kulkarni, S. S., and Buchholz, D. R. (2014). Corticosteroid signaling in frog metamorphosis. Gen. Comp. Endocrinol. 203, 225-231. doi: 10.1016/j.ygcen. 2014.03.036

Kulkarni, S. S., Denver, R. J., Gomez-Mestre, I., and Buchholz, D. R. (2017). Genetic accommodation via modified endocrine signalling explains phenotypic divergence among spadefoot toad species. Nat. Commun. 8, 1-6. doi: 10.1038/ s41467-017-00996-5

Kulkarni, S., and Buchholz, D. (2013). Developmental programs and endocrine disruption in frog metamorphosis: the perspective from microarray analysis. Curr. Top. Dev. Biol. 103, 329-364. doi: 10.1016/B978-0-12-385979-2.00012-5

Kwok, A. H. Y., Wang, Y., Wang, C. Y., and Leung, F. C. (2007). Cloning of chicken glucocorticoid receptor (GR) and characterization of its expression in pituitary and extrapituitary tissues. Poult. Sci. 86, 423-430. doi: 10.1093/ps/86.2.423

Lafont, A., Hardman, L., Dirks, R., von den Thillart, G., Tomkiewicz, J., and Dufour, S. (2014). "Characterization and regulation during reproduction of four nuclear corticosteroid receptors in the European eel, Anguilla anguilla," in Proceedings of the 10th International Symposium on Reproductive Physiology of Fish, olhão.

Lamers, W. H., Mooren, P. G., Griep, H., Endert, E., Degenhart, H. J., and Charles, R. (1986). Hormones in perinatal rat and spiny mouse: relation to altricial and precocial timing of birth. Am. J. Physiol. Endocrinol. Metab. 251, E78-E85. doi: 10.1152/ajpendo.1986.251.1.e78

Langdon, J. S., Thorpe, J. E., and Roberts, R. J. (1984). Effects of cortisol and acth on gill $\mathrm{Na}+/ \mathrm{K}+$-ATPase, SDH and chloride cells in juvenile atlantic salmon Salmo salar L. Comp. Biochem. Physiol. Part A Physiol. 77, 9-12. doi: 10.1016/03009629(84)90004-5

Langhorne, P., and Simpson, T. (1981). "Natural changes in serum cortisol in Atlantic salmon (Salmo salar L.) during parr-smolt transformation," in Stress and Fish, ed. A. Pickering (Cambridge, MA: Academic Press), 349-350.

Langhorne, P., and Simpson, T. H. (1986). The interrelationship of cortisol, Gill $(\mathrm{Na}+\mathrm{K})$ ATPase, and homeostasis during the Parr-Smolt transformation of atlantic salmon (Salmo salar L.). Gen. Comp. Endocrinol. 61, 203-213. doi: 10.1016/0016-6480(86)90198-X

Lazcano, I., and Orozco, A. (2018). Revisiting available knowledge on teleostean thyroid hormone receptors. Gen. Comp. Endocrinol. 265, 128-132. doi: 10.1016/ j.ygcen.2018.03.022

Le Roy, A., and Seebacher, F. (2020). Mismatched light and temperature cues disrupt locomotion and energetics via thyroid-dependent mechanisms. Conserv. Physiol. 8, 1-11. doi: 10.1093/conphys/coaa051

Lee, S., Ji, K., and Choi, K. (2014). Effects of water temperature on perchlorate toxicity to the thyroid and reproductive system of Oryzias latipes. Ecotoxicol. Environ. Saf. 108, 311-317. doi: 10.1016/j.ecoenv.2014.07.016

Leemans, M., Couderq, S., Demeneix, B., and Fini, J. B. (2019). Pesticides with potential thyroid hormone-disrupting effects: a review of recent data. Front. Endocrinol. (Lausanne) 10:743. doi: 10.3389/fendo.2019.00743

Leloup, I., Buscaglia, M., and de Luze, A. (1981). [Modulation of T4 to T3 conversion. Comparative aspects (author's transl)]. Ann. Endocrinol. (Paris) 42, $454-460$.

Leloup, J., and Buscaglia, M. (1977). Triiodothyronine, hormone of amphibian metamorphosis. Comptes Rendus Hebd. Des Seances L Acad. Des Sci. Ser. D 284, 2261-2263.

Lema, S. C., Chow, M. I., Resner, E. J., Westman, A. A., May, D., Dittman, A. H., et al. (2016). Endocrine and metabolic impacts of warming aquatic habitats: Differential responses between recently isolated populations of a eurythermal desert pupfish. Conserv. Physiol. 4, 1-17. doi: 10.1093/conphys/cow047

Li, X., Li, Z., Deng, Y., Zhang, J., Li, J., and Wang, Y. (2020). Characterization of a novel thyrotropin-releasing hormone receptor, TRHR3, in chickens. Poult. Sci. 99, 1643-1654. doi: 10.1016/j.psj.2019.10.062

Lien, S., Koop, B. F., Sandve, S. R., Miller, J. R., Kent, M. P., Nome, T., et al. (2016). The Atlantic salmon genome provides insights into rediploidization. Nature 533, 200-205. doi: 10.1038/nature17164

Liggins, G. C. (1968). Premature parturition after infusion of corticotrophin or cortisol into foetal lambs. J. Endocrinol. 42, 323-329. doi: 10.1677/joe.0. 0420323
Liggins, G. C. (1969). Premature delivery of foetal lambs infused with glucocorticoids. J. Endocrinol. 45, 515-523. doi: 10.1677/joe.0.0450515

Liggins, G., Schellenberg, J.-C., Manzal, M., Kitterman, J. A., and Lee, C.-C. (1988). Synergism of cortisol and thyrotropin-releasing hormone in lung maturation in fetal sheep. J. Appl. Physiol. 65, 1880-1884.

Lima, A., Ferreira, L., Silva, D., Gomes, F., and Titon, S. (2020). Thermal sensitivity of Bullfrog's immune response kept at different temperatures. J. Exp. Zool. A Ecol. Integr. Physiol. 333, 767-778. doi: 10.1002/jez.2436

Little, A. G. (2021). Thyroid hormone regulation of thermal acclimation in ectotherms: physiological mechanisms and ecoevolutionary implications. Mol. Cell. Endocrinol. 530:111285. doi: 10.1016/j.mce.2021.111285

Little, A. G., Kunisue, T., Kannan, K., and Seebacher, F. (2013). Thyroid hormone actions are temperature-specific and regulate thermal acclimation in zebrafish (Danio rerio). BMC Biol. 11:26. doi: 10.1186/1741-7007-11-26

Little, A. G., Loughland, I., and Seebacher, F. (2020). What do warming waters mean for fish physiology and fisheries? J. Fish Biol. 97, 328-340. doi: 10.1111/ jfb. 14402

Little, A., and Seebacher, F. (2014). Thyroid hormone regulates cardiac performance during cold acclimation in zebrafish (Danio rerio). J. Exp. Biol. 217, 718-725. doi: 10.1242/jeb.096602

Logan, D. W., Bryson-Richardson, R. J., Pagán, K. E., Taylor, M. S., Currie, P. D., and Jackson, I. J. (2003). The structure and evolution of the melanocortin and MCH receptors in fish and mammals. Genomics 81, 184-191. doi: 10.1016/ S0888-7543(02)00037-X

Lorgen, M., Casadei, E., Król, E., Douglas, A., Birnie, M. J., Ebbesson, L. O. E., et al. (2015). Functional divergence of type 2 deiodinase paralogs in the Atlantic salmon. Curr. Biol. 25, 936-941. doi: 10.1016/j.cub.2015. 01.074

Lovejoy, D. A., and Balment, R. J. (1999). Evolution and physiology of corticotropin-releasing factor (CRF) family of neuropeptides in vertebrates. Gen. Comp.Endocrinol. 115, 1-22.

Lovejoy, D. A., Chang, B. S. W., Lovejoy, N. R., and del Castillo, J. (2014). Molecular evolution of GPCRs: CRH/CRH receptors. J. Mol. Endocrinol. 52, T46-T60. doi: 10.1530/JME-13-0238

Luzeena Raja, G., Divya Subhashree, K., Lite, C., Santosh, W., and Barathi, S. (2019). Transient exposure of methylparaben to zebrafish (Danio rerio) embryos altered cortisol level, acetylcholinesterase activity and induced anxietylike behaviour. Gen. Comp. Endocrinol. 279, 53-59. doi: 10.1016/j.ygcen.2018. 11.001

Madsen, S. S. (1990). The role of cortisol and growth hormone in seawater adaptation and development of hypoosmoregulatory mechanisms in sea trout parr (Salmo trutta trutta). Gen. Comp. Endocrinol. 79, 1-11. doi: 10.1016/00166480(90)90082-W

Manchado, M., Infante, C., Rebordinos, L., and Cañavate, J. P. (2009). Molecular characterization, gene expression and transcriptional regulation of thyroid hormone receptors in Senegalese sole. Gen. Comp. Endocrinol. 160, 139-147. doi: 10.1016/j.ygcen.2008.11.001

Männistö, T., Mendola, P., Reddy, U., and Laughon, S. K. (2013). Neonatal outcomes and birth weight in pregnancies complicated by maternal thyroid disease. Am. J. Epidemiol. 178, 731-740. doi: 10.1093/aje/kwt031

Marchand, O., Duffraisse, M., Triqueneaux, G., Safi, R., and Laudet, V. (2004). Molecular cloning and developmental expression patterns of thyroid hormone receptors and T3 target genes in the turbot (Scophtalmus maximus) during postembryonic development. Gen. Comp. Endocrinol. 135, 345-357. doi: 10.1016/j. ygcen.2003.10.012

Marchand, O., Safi, R., Escriva, H., Van Rompaey, E., Prunet, P., and Laudet, V. (2001). Molecular cloning and characterization of thyroid hormone receptors in teleost fish. J. Mol. Endocrinol. 26, 51-65. doi: 10.1677/jme.0.026 0051

Marie, C. (1981). Ontogenesis of the adrenal glucocorticoids and of the target function of the enzymatic tyrosine transaminase activity in the chick embryo. J. Endocrinol. 90, 193-200.

Mashaly, M. M. (1991). Effect of exogenous corticosterone on chicken embryonic development. Poult. Sci. 70, 371-374. doi: 10.3382/ps.0700371

Maugars, G., Dufour, S., Cohen-Tannoudji, J. L., and Quérat, B. (2014). Multiple thyrotropin b-subunit and thyrotropin receptor-related genes arose during vertebrate evolution. PLoS One 9:e111361. doi: 10.1371/journal.pone.011 1361 
Maugars, G., Mauvois, X., Rousseau, K., and Dufour, S. (2016). "Evolution of the corticotropin-releasing hormone paralogs in teleosts," in Proceedings of the 8th International Symposium on Fish Endocrinology, Gothenburg.

Mazurais, D., Ducouret, B., Tujague, M., Valotaire, Y., D’Cotta, H., Gallais, C., et al. (1998). Regulation of the glucocorticoid receptor mRNA levels in the gills of Atlantic salmon (Salmo salar) during smoltification. Bull. Fr. Pêche Piscic. 350-351, 499-510.

McBride, J., Higgs, D., Fagerlund, U., and Buckley, J. (1982). Thyroid hormones and steroid hormones: potential for control of growth and smoltification of salmonids. Aquaculture 28, 201-210.

McCormick, S. D. (2001). Endocrine control of osmoregulation in teleost fish. Am. Zool. 41, 781-794. doi: 10.1093/icb/41.4.781

McCormick, S. D. (2012). Smolt physiology and endocrinology. Fish Physiol. 32, 199-251. doi: 10.1016/B978-0-12-396951-4.00005-0

McCormick, S. D., Dickhoff, W. W., Duston, J., Nishioka, R. S., and Bern, H. A. (1991). Developmental differences in the responsiveness of gill $\mathrm{Na}+, \mathrm{K}+$-ATPase to cortisol in salmonids. Gen. Comp. Endocrinol. 84, 308-317. doi: 10.1016/ 0016-6480(91)90054-A

McCormick, S. D., Lerner, D. T., Monette, M. Y., Nieves-Puigdoller, K., Kelly, J. T., and Björnsson, B. T. (2009). Taking it with you when you go: how perturbations to the freshwater environment, including temperature, dams, and contaminants, affect marine survival of salmon. Am. Fish. Soc. Symp. 69, 195-214.

McCormick, S. D., Regish, A., O’Dea, M. F., and Shrimpton, J. M. (2008). Are we missing a mineralocorticoid in teleost fish? Effects of cortisol, deoxycorticosterone and aldosterone on osmoregulation, gill $\mathrm{Na}+\mathrm{K}+$-ATPase activity and isoform mRNA levels in Atlantic salmon. Gen. Comp. Endocrinol. 157, 35-40. doi: 10.1016/j.ygcen.2008.03.024

McGlashan, J. K., Thompson, M. B., Van Dyke, J. U., and Spencer, R. J. (2017). Thyroid hormones reduce incubation period without developmental or metabolic costs in murray river short-necked turtles (Emydura macquarii). Physiol. Biochem. Zool. 90, 34-46. doi: 10.1086/689744

McLean, M., Bisits, A., Davies, J., Woods, R., Lowry, P., and Smith, R. (1995). A placental clock controlling the length of human pregnancy. Nat. Med. 1, 460-463. doi: 10.1038/nm0595-460

McLeese, J. M., Johnsson, J., Huntley, T. F. M., Clarke, W. C., and Weisbart, M. (1994). Seasonal changes in osmoregulation, cortisol, and cortisol receptor activity in the gills of parr/smolt of steelhead trout and steelhead-rainbow trout hybrids, Oncorhynchus mykiss. Gen. Comp. Endocrinol. 93, 103-113. doi: 10.1006/gcen.1994.1012

McNabb, F. M. A. (2006). Avian thyroid development and adaptive plasticity. Gen. Comp. Endocrinol. 147, 93-101. doi: 10.1016/j.ygcen.2005.12.011

McNabb, F. M. A., Stanton, F. W., and Dicken, S. G. (1984). Post-hatching thyroid development and body growth in precocial vs altricial birds. Comp. Biochem. Physiol. Part A Physiol. 78, 629-635. doi: 10.1016/0300-9629(84)9 0609-1

Medler, K. F., and Lance, V. A. (1998). Sex differences in plasma corticosterone levels in alligator (Alligator mississippiensis) embryos. J. Exp. Zool. 280, 238-244.

Mekuchi, M., Saito, Y., Aoki, Y., Masuda, T., Iigo, M., and Yanagisawa, T. (2011). Molecular cloning, gene structure, molecular evolution and expression analyses of thyrotropin-releasing hormone receptors from medaka (Oryzias latipes). Gen. Comp. Endocrinol. 170, 374-380. doi: 10.1016/j.ygcen.2010.10.013

Metz, J. R., Geven, E. J. W., Van Den Burg, E. H., and Flik, G. (2005). ACTH, $\alpha-\mathrm{MSH}$, and control of cortisol release: cloning, sequencing, and functional expression of the melanocortin-2 and melanocortin-5 receptor in Cyprinus carpio. Am. J. Physiol. Regul. Integr. Comp. Physiol. 289, 814-826. doi: 10.1152/ ajpregu.00826.2004

Meyer, A., and Schartl, M. (1999). Gene and genome duplications in vertebrates: the one-to-four (-to-eight in fish) rule and the evolution of novel gene functions. Curr. Opin. Cell Biol. 11, 699-704. doi: 10.1016/S0955-0674(99)0 0039-3

Miranda, L. A., Affanni, J. M., and Paz, D. A. (2000). Corticotropin-releasing factor accelerates metamorphosis in Bufo arenarum: effect on pituitary ACTH and TSH cells. J. Exp. Zool. 286, 473-480.

Miwa, S., and Inui, Y. (1983). Effects of thyroxine and thiourea on the parr-smolt transformation of amago salmon (Oncorhynchus rhodurus). Bull. Natl. Res. Inst. Aquac. 4, 41-52.
Miwa, S., and Inui, Y. (1985). Effects of l-thyroxine and ovine growth hormone on smoltification of amago salmon (Oncorhynchus rhodurus). Gen. Comp. Endocrinol. 58, 436-442. doi: 10.1016/0016-6480(85)90116-9

Miwa, S., and Inui, Y. (1987). Effects of various doses of thyroxine and triiodothyronine on the metamorphosis of flounder (Paralichthys olivaceus). Gen. Comp. Endocrinol. 67, 356-363. doi: 10.1016/0016-6480(87)90190-0

Miwa, S., Tagawa, M., Inui, Y., and Hirano, T. (1988). Thyroxine surge in metamorphosing flounder larvae. Gen. Comp. Endocrinol. 70, 158-163. doi: 10.1016/0016-6480(88)90105-0

Mizuno, S., Ura, K., Onodera, Y., Fukada, H., Misaka, N., Hara, A., et al. (2001). Changes in transcript levels of gill cortisol receptor during smoltification in Wild Masu Salmon, Oncorhynchus masou. Zool. Sci. 18, 853-860. doi: 10.2108/ zsj. 18.853

Mommsen, T. P., Vijayan, M. M., and Moon, T. W. (1999). Cortisol in teleosts: dynamics, mechanisms of action, and metabolic regulation. Rev. Fish Biol. Fish. 9, 211-268. doi: 10.1023/A:1008924418720

Moore, C. S., Cristol, D. A., Maddux, S. L., Varian-Ramos, C. W., and Bradley, E. L. (2014). Lifelong exposure to methylmercury disrupts stress-induced corticosterone response in zebra finches (Taeniopygia guttata). Environ. Toxicol. Chem. 33, 1072-1076. doi: 10.1002/etc.2521

Moreira, L., Diamante, G., Giroux, M., Coffin, S., Xu, E., Moledo de Souza Abessa, D., et al. (2018). Impacts of salinity and temperature on the thyroidogenic effects of the biocide diuron in Menidia beryllina. Env. Sci. Technol. 52, 3146-3155. doi: 10.1021/acs.est.7b04970

Mulay, S., Giannopoulos, G., and Solomon, S. (1973). Corticosteroid levels in mother an dfetus of the rabbit during gestation. Endocrinology 93, 1342-1348.

Nagae, M., Fuda, H., Hara, A., Saneyoshi, M., and Yamauchi, K. (1994). Changes in serum concentrations of immunoglobulin M (IgM), cortisol and thyroxine (T4) during Smoltification in the Masu Salmon Oncorhynchus masou. Fish. Sci. 60, 241-242. doi: 10.2331/fishsci.60.241

Nakane, Y., and Yoshimura, T. (2019). Photoperiodic regulation of reproduction in vertebrates. Annu. Rev. Anim. Biosci. 7, 173-194.

Nakano, M., Hasunuma, I., Minagawa, A., Iwamuro, S., Yamamoto, K., Kikuyama, S., et al. (2018). Possible involvement of thyrotropin-releasing hormone receptor 3 in the release of prolactin in the metamorphosing bullfrog larvae. Gen. Comp. Endocrinol. 267, 36-44. doi: 10.1016/j.ygcen.2018.05.029

Nisenbaum, L., Martin, P., Fuentes, M., Besseau, L., Magnanou, E., McCormick, S., et al. (2020). Effects of a temperature rise on melatonin and thyroid hormones during smoltification of Atlantic salmon, Salmo salar. J. Comp. Physiol. B 190, 731-748. doi: 10.1007/s00360-020-01304-2

O'Shaughnessy, K. L., and Gilbert, M. E. (2020). Thyroid disrupting chemicals and developmental neurotoxicity - new tools and approaches to evaluate hormone action. Mol. Cell. Endocrinol. 518:110663. doi: 10.1016/j.mce.2019.110663

Olivereau, M. (1975). Histophysiologie de l'axe hypophyso-corticosurrenalien chez le saumon de l'Atlantique (Cycle en eau douce, vie thalassique et reproduction). Gen. Comp. Endocrinol. 27, 9-27.

Olson, J. M., McNabb, F. M. A., Jablonski, M. S., and Ferris, D. V. (1999). Thyroid development in relation to the development of endothermy in the red-winged blackbird (Agelaius phoeniceus). Gen. Comp. Endocrinol. 116, 204-212. doi: 10.1006/gcen.1999.7363

On, J. S. W., Arokiaraj, A. W. R., and Chow, B. K. C. (2019). Molecular evolution of CRH and CRHR subfamily before the evolutionary origin of vertebrate. Peptides 120:170087. doi: 10.1016/j.peptides.2019.04.014

Orozco, A., and Valverde-R, C. (2005). Thyroid hormone deiodination in fish. Thyroid 15, 799-813. doi: 10.1089/thy.2005.15.799

Orozco, A., Valverde, R. C., Olvera, A., and García, G. C. (2012). Iodothyronine deiodinases: a functional and evolutionary perspective. J. Endocrinol. 215, 207-219. doi: 10.1530/JOE-12-0258

Ortiz-Santaliestra, M., and Marco, A. (2015). Influence of dissolved oxygen conditions on toxicity of ammonium nitrate to larval natterjack toads. Arch. Env. Contam. Toxicol. 69, 95-103. doi: 10.1007/s00244-014-0126-3

Orton, F., and Tyler, C. R. (2015). Do hormone-modulating chemicals impact on reproduction and development of wild amphibians? Biol. Rev. 90, 1100-1117. doi: 10.1111/brv.12147

Owens, D., and Morris, Y. (1985). The comparative endocrinology of sea turtles. Copeia 3, 723-735.

Paris, M., and Laudet, V. (2008). The history of a developmental stage: metamorphosis in chordates. Genesis 46, 657-672. doi: 10.1002/dvg.20443 
Parisi, C., and Guerriero, G. (2019). Antioxidative defense and fertility rate in the assessment of reprotoxicity risk posed by global warming. Antioxidants 8:622. doi: 10.3390/antiox8120622

Park, D., Freel, K. L., Daniels, K. D., and Propper, C. R. (2016). Interactions between a small chronic increase in diel water temperature and exposure to a common environmental contaminant on development of Arizona tiger salamander larvae. Gen. Comp. Endocrinol. 238, 69-77. doi: 10.1016/j.ygcen. 2016.06.021

Patel, J., Landers, K., Li, H., Mortimer, R. H., and Richard, K. (2011). Thyroid hormones and fetal neurological development. J. Endocrinol. 209, 1-8. doi: 10.1530/JOE-10-0444

Petrović, T. G., Kijanović, A., Tomašević, N. K., Gavrić, J. P., Despotović, S. G., Gavrilović, B. R., et al. (2021). Effects of desiccation on metamorphic climax in Bombina variegata: changes in levels and patterns of oxidative stress parameters. Animals 11:953. doi: 10.3390/ani11040953

Pinsky, M., Eikeset, A., McCauley, D., Payne, J., and Sunday, J. (2019). Greater vulnerability to warming of marine versus terrestrial ectotherms. Nature 569, 108-111. doi: 10.1038/s41586-019-1132-4

Porter, T. E., Ghavam, S., Muchow, M., Bossis, I., and Ellestad, L. (2007). Cloning of partial cDNAs for the chicken glucocorticoid and mineralocorticoid receptors and characterization of mRNA levels in the anterior pituitary gland during chick embryonic development. Domest. Anim. Endocrinol. 33, 226-239. doi: 10.1016/j.domaniend.2006.05.006

Pottinger, T. G. (2017). Modulation of the stress response in wild fish is associated with variation in dissolved nitrate and nitrite. Environ. Pollut. 225, 550-558. doi: 10.1016/j.envpol.2017.03.021

Préau, L., Fini, J. B., Morvan-Dubois, G., and Demeneix, B. (2015). Thyroid hormone signaling during early neurogenesis and its significance as a vulnerable window for endocrine disruption. Biochim. Biophys. Acta Gene Regul. Mech. 1849, 112-121. doi: 10.1016/j.bbagrm.2014.06.015

Premdas, F., and Eales, J. (1976). The influence of TSH and ACTH on purine and pteridine deposition in the skin of rainbow trout (Salmo gairdneri). Can. J. Zool. 54, 576-581.

Quan, J., Kang, Y., Luo, Z., Zhao, G., Ma, F., Li, L., et al. (2020). Identification and characterization of long noncoding RNAs provide insight into the regulation of gene expression in response to heat stress in rainbow trout (Oncorhynchus mykiss). Comp. Biochem. Physiol. Part D Genomics Proteomics 36:100707. doi: 10.1016/j.cbd.2020.100707

Racic, A., Tylan, C., and Langkilde, T. (2020). Effects of temperature on plasma corticosterone in a native lizard. Sci. Rep. 10, 1-8. doi: 10.1038/s41598-02073354-z

Radchuk, V., Reed, T., Teplitsky, C., van de Pol, M., Charmantier, A., Hassall, C., et al. (2019). Adaptive responses of animals to climate change are most likely insufficient. Nat. Commun. 10, 1-14. doi: 10.1038/s41467-019-10924-4

Raine, J. C., Cameron, C., Vijayan, M. M., MacKenzie, D. S., and Leatherland, J. F. (2005). Effect of fasting on thyroid hormone levels, and TR $\alpha$ and TR $\beta$ mRNA accumulation in late-stage embryo and juvenile rainbow trout, Oncorhynchus mykiss. Comp. Biochem. Physiol. A Mol. Integr. Physiol. 140, 452-459. doi: 10.1016/j.cbpb.2005.02.007

Ranjan, M., Wong, J., and Shi, Y. B. (1994). Transcriptional repression of Xenopus $\operatorname{TR} \beta$ gene is mediated by a thyroid hormone response element located near the start site. J. Biol. Chem. 269, 24699-24705. doi: 10.1016/s0021-9258(17)31 447-3

Redding, J. M., Patiño, R., and Schreck, C. B. (1991). Cortisol effects on plasma electrolytes and thyroid hormones during smoltification in coho salmon Oncorhynchus kisutch. Gen. Comp. Endocrinol. 81, 373-382. doi: 10.1016/00166480(91)90164-2

Reddy, P. K., and Lam, T. J. (1991). Effect of thyroid hormones on hatching in the tilapia, Oreochromis mossambicus. Gen. Comp. Endocrinol. 81, 484-491.

Reyns, G. E., Venken, K., Morreale De Escobar, G., Kühn, E. R., and Darras, V. M. (2003). Dynamics and regulation of intracellular thyroid hormone concentrations in embryonic chicken liver, kidney, brain, and blood. Gen. Comp. Endocrinol. 134, 80-87. doi: 10.1016/S0016-6480(03)00220-X

Richman, N. H., Tai de Diaz, S., Nishioka, R. S., Prunet, P., and Bern, H. A. (1987). Osmoregulatory and endocrine relationships with chloride cell morphology and density during smoltification in coho salmon (Oncorhynchus kisutch). Aquaculture 60, 265-285. doi: 10.1016/0044-8486(87)90293-6
Robertson, O. (1949). Production of silvery smolt stage in rainbow trout by intramuscular injection of mammalian thyroid extract and thyrotropic hormone. J. Exp. Zool. 110, 337-355.

Romanoff, A., and Laufer, H. (1956). The effect of injected thiourea on the development of some organs of the chick embryo. Endocrinology 59, 611-619. doi: 10.1210/endo-59-6-611

Rondeau, E. B., Minkley, D. R., Leong, J. S., Messmer, A. M., Jantzen, J. R., Von Schalburg, K. R., et al. (2014). The genome and linkage map of the northern pike (Esox lucius): conserved synteny revealed between the salmonid sister group and the neoteleostei. PLoS One 9:e102089. doi: 10.1371/journal.pone.010 2089

Rousseau, J. P., Buteau-Poulin, A., and Kinkead, R. (2019). Maternal thyroid hormone deficiency and cardiorespiratory disorder in rat pups. Exp. Neurol. 320:112960. doi: 10.1016/j.expneurol.2019.112960

Rousseau, K., Martin, P., Boeuf, G., and Dufour, S. (2012). "Salmonid secondary metamorphosis: smoltification," in Metamorphosis in Fish, eds S. Dufour, K. Rousseau, and B. Kappor (St Helier: Science Publishers), 167-215.

Routti, H., Atwood, T. C., Bechshoft, T., Boltunov, A., Ciesielski, T. M., Desforges, J. P., et al. (2019). State of knowledge on current exposure, fate and potential health effects of contaminants in polar bears from the circumpolar Arctic. Sci. Total Environ. 664, 1063-1083. doi: 10.1016/j.scitotenv.2019.02.030

Rubolini, D., Romano, M., Boncoraglio, G., Ferrari, R. P., Martinelli, R., Galeotti, P., et al. (2005). Effects of elevated egg corticosterone levels on behavior, growth, and immunity of yellow-legged gull (Larus michahellis) chicks. Horm. Behav. 47, 592-605. doi: 10.1016/j.yhbeh.2005.01.006

Rupik, W. (2011). Structural and ultrastructural differentiation of the thyroid gland during embryogenesis in the grass snake Natrix natrix L. (Lepidosauria, Serpentes). Zoology 114, 284-297. doi: 10.1016/j.zool.2011.05.002

Ruthsatz, K., Dausmann, K. H., Drees, C., Becker, L. I., Hartmann, L., Reese, J., et al. (2020). Altered thyroid hormone levels affect the capacity for temperatureinduced developmental plasticity in larvae of Rana temporaria and Xenopus laevis. J. Therm. Biol. 90:102599. doi: 10.1016/j.jtherbio.2020.102599

Ruuskanen, S., Groothuis, T. G. G., Schaper, S. V., Darras, V. M., de Vries, B., and Visser, M. E. (2016). Temperature-induced variation in yolk androgen and thyroid hormone levels in avian eggs. Gen. Comp. Endocrinol. 235, 29-37. doi: 10.1016/j.ygcen.2016.05.026

Ruuskanen, S., Hsu, B. Y., and Nord, A. (2021). Endocrinology of thermoregulation in birds in a changing climate. Mol. Cell. Endocrinol. 519:111088. doi: 10.1016/ j.mce.2020.111088

Sachs, L. M., and Buchholz, D. R. (2017). Frogs model man: in vivo thyroid hormone signaling during development. Genesis 55, e23000. doi: 10.1002/dvg. 23000

Sachs, L. M., and Buchholz, D. R. (2019). Insufficiency of thyroid hormone in frog metamorphosis and the role of glucocorticoids. Front. Endocrinol. (Lausanne) 10:287. doi: 10.3389/fendo.2019.00287

Sachs, L., Damjanovski, S., Jones, P., Li, Q., Amano, T., Ueda, S., et al. (2000). Dual functions of thyroid hormone receptors during Xenopus development. Comp. Biochem. Physiol. B Biochem. Mol. Biol. 126, 199-211.

Saffran, M., Schally, A., and Benfey, B. (1955). Stimulation of the release of corticotropin from the adenohypophysis by a neurohypophysial factor. Endocrinology 57, 439-444.

Saino, N., Romano, M., Ferrari, R. P., Martinelli, R., and Møller, A. P. (2005). Stressed mothers lay eggs with high corticosterone levels which produce lowquality offspring. J. Exp. Zool. Part A Comp. Exp. Biol. 303, 998-1006. doi: 10.1002/jez.a.224

Saito, Y., Mekuchi, M., Kobayashi, N., Kimura, M., Aoki, Y., Masuda, T., et al. (2011). Molecular cloning, molecular evolution and gene expression of cDNAs encoding thyrotropin-releasing hormone receptor subtypes in a teleost, the sockeye salmon (Oncorhynchus nerka). Gen. Comp. Endocrinol. 174, 80-88. doi: 10.1016/j.ygcen.2011.07.011

Salis, P., Roux, N., Huang, D., Marcionetti, A., Mouginot, P., Reynaud, M., et al. (2021). Thyroid hormones regulate the formation and environmental plasticity of white bars in clownfishes. Proc. Natl. Acad. Sci. U.S.A. 118, 1-9. doi: 10.1073/ pnas. 2101634118

Sangild, P. T., Fowden, A. L., and Trahair, J. F. (2000). How does the foetal gastrointestinal tract develop in preparation for enteral nutrition after birth? Livest. Prod. Sci. 66, 141-150. doi: 10.1016/S0301-6226(00) 00221-9 
Sap, J., Muñoz, A., Damm, K., Goldberg, Y., Ghysdael, J., Leutz, A., et al. (1986). The c-erb-A protein is a high-affinity receptor for thyroid hormone. Nature 324, 635-640. doi: 10.1038/324635a0

Sarraude, T., Hsu, B. Y., Groothuis, T., and Ruuskanen, S. (2020). Testing the shortand long-term effects of elevated prenatal exposure to different forms of thyroid hormones. PeerJ 8, 1-25. doi: 10.7717/peerj.10175

Saunders, R. L., McCormick, S. D., Henderson, E. B., Eales, J. G., and Johnston, C. E. (1985). The effect of orally administered 3,5,3'-triiodo-L-thyronine on growth and salinity tolerance of Atlantic salmon (Salmo salar L.). Aquaculture 45, 143-156. doi: 10.1016/0044-8486(85)90265-0

Schaaf, M. J. M., Champagne, D., Van Laanen, I. H. C., Van Wijk, D. C. W. A., Meijer, A. H., Meijer, O. C., et al. (2008). Discovery of a functional glucocorticoid receptor $\beta$-isoform in zebrafish. Endocrinology 149, 1591-1598. doi: 10.1210/en.2007-1364

Schellenberg, J., Liggins, G., Manzai, M., Kitterman, J., and Lee, C. (1988). Synergistic hormonal effects on lung maturation in fetal sheep. J. Appl. Physiol. 65, 94-100.

Schmidt, J., Andree, R., Davis, K., Treese, S., and Satterlee, D. (2009). Influence of maternal corticosterone treatment on incubation length of eggs laid by Japanese quail hens selected for divergent adrenocortical stress responsiveness. Br. Poult. Sci. 50, 739-747. doi: 10.1080/00071660903317571

Schreiber, A. M., and Specker, J. L. (1998). Metamorphosis in the summer flounder, Paralichthys dentatus: stage-specific developmental response to altered thyroid status. Gen. Comp. Endocrinol. 111, 156-166.

Schreiber, V., Eckertova, A., Franc, Z., Koci, J., Rybak, M., and Kmentova, V. (1961). Effect of a fraction of bovine hypothalamic extract on the release of TSH by rat adenohypophyses in vitro. Experientia 17, 264-265.

Schriks, M., van der Linden, S. C., Stoks, P. G. M., van der Burg, B., Puijker, L., de Voogt, P., et al. (2013). Occurrence of glucocorticogenic activity in various surface waters in The Netherlands. Chemosphere 93, 450-454. doi: 10.1016/j. chemosphere.2013.04.091

Scott, T. R., Johnson, W. A., Satterlee, D. G., and Gildersleeve, R. P. (1981). Circulating levels of corticosterone in the serum of developing chick embryos and newly hatched chicks. Poult. Sci. 60, 1314-1320. doi: 10.3382/ps.0601314

Shepherdley, C. A., Daniels, C. B., Orgeig, S., Richardson, S. J., Evans, B. K., and Darras, V. M. (2002). Glucocorticoids, thyroid hormones, and iodothyronine deiodinases in embryonic saltwater crocodiles. Am. J. Physiol. Regul. Integr. Comp. Physiol. 283, 1155-1163. doi: 10.1152/ajpregu.00015.2002

Shi, Y. B. (2021). Life without thyroid hormone receptor. Endocrinology (United States) 162, 1-12. doi: 10.1210/endocr/bqab028

Shi, Y. B., Liang, V. C. T., Parkison, C., and Cheng, S. Y. (1994). Tissue-dependent developmental expression of a cytosolic thyroid hormone protein gene in Xenopus: its role in the regulation of amphibian metamorphosis. FEBS Lett. 355, 61-64. doi: 10.1016/0014-5793(94)01173-7

Shibata, Y., Tanizaki, Y., Zhang, H., Lee, H., Dasso, M., and Shi, Y. B. (2021). Thyroid hormone receptor is essential for larval epithelial apoptosis and adult epithelial stem cell development but not adult intestinal morphogenesis during Xenopus tropicalis metamorphosis. Cells 10:536. doi: 10.3390/cells10030536

Shibata, Y., Wen, L., Okada, M., and Shi, Y. (2020). Organ-specific requirements for thyroid hormone receptor ensure temporal coordination of tissue-specific transformations and completion of Xenopus Metamorphosis. Thyroid 30, 300313. doi: 10.1089/thy.2019.0366

Shibusawa, K., Saito, S., Fukuda, M., Kawai, T., and Yoshimura, F. (1955). On the role of the hypothalamic-neurohypophyseal neurosecretion in the liberation of the adenohypophyseal hormines. Endocrinol. Jpn. 2, 47-56.

Shin, H. S., Choi, Y. J., Kim, N. N., Lee, J., Ueda, H., and Choi, C. Y. (2014). Effects of exogenous cortisol and seawater adaptation on thyroid hormone receptors in the smolt stage of the sockeye salmon, Oncorhynchus nerka. Ichthyol. Res. 61, 9-16. doi: 10.1007/s10228-013-0365-8

Shrimpton, J. M. (1996). Relationship between size, gill corticosteroid receptors, $\mathrm{Na}+\mathrm{K}+\mathrm{ATPase}$ activity and smolting in juvenile coho salmon (Oncorhynchus kisutch) in autumn and spring. Aquaculture 147, 127-140. doi: 10.1016/S00448486(96)01390-7

Shrimpton, J. M., and McCormick, S. D. (1998). Seasonal differences in plasma cortisol and gill corticosteroid receptors in upper and lower mode juvenile Atlantic salmon. Aquaculture 168, 205-219. doi: 10.1016/S0044-8486(98) 00350-0
Shrimpton, J. M., and McCormick, S. D. (1999). Responsiveness of gill Na+/K+ATPase to cortisol is related to gill corticosteroid receptor concentration in juvenile rainbow trout. J. Exp. Biol. 202, 987-995.

Shrimpton, J. M., and McCormick, S. D. (2003). Environmental and endocrine control of gill corticosteroid receptor number and affinity in Atlantic salmon (Salmo salar) during smolting. Aquaculture 222, 83-99. doi: 10.1016/S00448486(03)00104-2

Shrimpton, J., and Randall, D. (1994). Downregulation of corticosteroid receptors in gills of coho salmon due to stress and cortisol treatment. Am. J. Physiol. Integr. Comp. Physiol. 267, R432-R438.

Siegel, H. S., and Gould, N. R. (1976). Chick embryonic plasma proteins and binding capacity for corticosterone. Dev. Biol. 50, 510-516. doi: 10.1016/00121606(76)90169-X

Silver, M., and Fowden, A. L. (1989). Pituitary-adrenocortical activity in the fetal pig in the last third of gestation. Q. J. Exp. Physiol. 74, 197-206. doi: 10.1113/ expphysiol.1989.sp003255

Silverin, B., and Rudas, P. (1996). Thyroid hormones in nestling great tits (Parus major). Gen. Comp. Endocrinol. 103, 138-141. doi: 10.1006/gcen.1996.0104

Sinha, M. D., Ringer, R. K., Coleman, T. H., and Zindel, H. C. (1959). The effect of injected thiouracil on body weight and hatchability of the chick embryo. Poult. Sci. 38, 1405-1409. doi: 10.3382/ps.0381405

Sirakov, M., and Plateroti, M. (2011). The thyroid hormones and their nuclear receptors in the gut: from developmental biology to cancer. Biochim. Biophys. Acta Mol. Basis Dis. 1812, 938-946. doi: 10.1016/j.bbadis.2010. 12.020

Sirakov, M., Kress, E., Nadjar, J., and Plateroti, M. (2014). Thyroid hormones and their nuclear receptors: new players in intestinal epithelium stem cell biology? Cell. Mol. Life Sci. 71, 2897-2907. doi: 10.1007/s00018-014-1586-3

Sirsat, T. S., and Dzialowski, E. M. (2020). Manipulating plasma thyroid hormone levels at hatching alters development of endothermy and ventilation in Pekin duck (Anas platyrhynchos domestica). J. Exp. Biol. 223(Pt 22):jeb237701. doi: $10.1242 /$ jeb. 237701

Sjöberg, M., Vennström, B., and Forrest, D. (1992). Thyroid hormone receptors in chick retinal development: differential expression of mRNAs for $\alpha$ and N-terminal variant $\beta$ receptors. Development $114,39-47$.

Solbakken, J. S., Norberg, B., Watanabe, K., and Pittman, K. (1999). Thyroxine as a mediator of metamorphosis of Atlantic halibut, Hippoglossus hippoglossus. Environ. Biol. Fishes 56, 53-65. doi: 10.1023/a:1007542526040

Spaan, K., Haigis, A. C., Weiss, J., and Legradi, J. (2019). Effects of 25 thyroid hormone disruptors on zebrafish embryos: a literature review of potential biomarkers. Sci. Total Environ. 656, 1238-1249. doi: 10.1016/j.scitotenv.2018. 11.071

Specker, J. L. (1982). Interrenal function and smoltification. Aquaculture 28, 59-66. doi: 10.1016/0044-8486(82)90008-4

Specker, J. L., Eales, J. G., Tagawa, M., and Tyler, W. A. (2000). Parr-smolt transformation in Atlantic salmon: thyroid hormone deiodination in liver and brain and endocrine correlates of change in rheotactic behavior. Can. J. Zool. 78, 696-705. doi: 10.1139/z99-258

Specker, J., and Schreck, C. (1982). Changes in plasma corticosteroids during smoltification of coho salmon Oncorhynchus kisutch. Gen. Comp. Endocrinol. 46, 53-58.

Spirhanzlova, P., Fini, J. B., Demeneix, B., Lardy-Fontan, S., Vaslin-Reimann, S., Lalere, B., et al. (2019). Composition and endocrine effects of water collected in the Kibale national park in Uganda. Environ. Pollut. 251, 460-468. doi: 10.1016/j.envpol.2019.05.006

St. Germain, D. L., Schwartzman, R. A., Croteau, W., Kanamori, A., Wang, Z., Brown, D. D., et al. (1994). A thyroid hormone-regulated gene in Xenopus laevis encodes a type III iodothyronine 5-deiodinase. Proc. Natl. Acad. Sci. U.S.A 91, 7767-7771. doi: 10.1073/pnas.91.16. 7767

Starck, J., and Ricklefs, R. (1998). "Patterns of development: the altricial-precocial spectrum," in Avian Growth And Development, eds J. Starck and R. Ricklefs (Oxford: Oxford Univ. Press), 3-30.

Steegborn, C., and Schweizer, U. (2020). Structure and mechanism of iodothyronine deiodinases - what we know, what we don't know, and what would be nice to know. Exp. Clin. Endocrinol. Diabetes 128, 375-378. doi: 10.1055/a-1022-9916 
Stenzel, D., and Huttner, W. B. (2013). Role of maternal thyroid hormones in the developing neocortex and during human evolution. Front. Neuroanat. 7:19. doi: 10.3389/fnana.2013.00019

Sterner, Z. R., Shewade, L. H., Mertz, K. M., Sturgeon, S. M., and Buchholz, D. R. (2020). Glucocorticoid receptor is required for survival through metamorphosis in the frog Xenopus tropicalis. Gen. Comp. Endocrinol. 291:113419. doi: 10.1016/ j.ygcen.2020.113419

Sullivan, L. C., Orgeig, S., and Daniels, C. B. (2002a). Control of the development of the pulmonary surfactant system in the saltwater crocodile, Crocodylus porosus. Am. J. Physiol. Regul. Integr. Comp. Physiol. 283, 1164-1176. doi: 10.1152/ ajpregu.00009.2002

Sullivan, L. C., Orgeig, S., and Daniels, C. B. (2002b). Regulation of pulmonary surfactant secretion in the developing lizard, Pogona vitticeps. Comp. Biochem. Physiol. A Mol. Integr. Physiol. 133, 539-546. doi: 10.1016/S1095-6433(02) 00187-3

Sullivan, L. C., Orgeig, S., Wood, P. G., and Daniels, C. B. (2001). The ontogeny of pulmonary surfactant secretion in the embryonic green sea turtle (Chelonia mydas). Physiol. Biochem. Zool. 74, 493-501. doi: 10.1086/322158

Sullivan, L., Orgeig, S., and Daniels, C. (2003). The role of extrinsic and intrinsic factors in the evolution of the control of pulmonary surfactant maturation during development in the amniotes. Physiol. Biochem. Zool. 76, 281-295.

Sun, B. J., Li, T., Mu, Y., McGlashan, J. K., Georges, A., Shine, R., et al. (2016). Thyroid hormone modulates offspring sex ratio in a turtle with temperaturedependent sex determination. Proc. R. Soc. B Biol. Sci. 283:20161206. doi: 10. 1098/rspb.2016.1206

Sundell, H., Gray, M., Relier, J.-P., Kovar, I., Catterton, W., Switt, L., et al. (1979). The effects of ACTH on lung maturation in fetal lambs. Am. J. Pathol. 97, 393-410.

Sundell, K., Jutfelt, F., Ágústsson, T., Olsen, R. E., Sandblom, E., Hansen, T., et al. (2003). Intestinal transport mechanisms and plasma cortisol levels during normal and out-of-season parr-smolt transformation of Atlantic salmon Salmo salar. Aquaculture 222, 265-285. doi: 10.1016/S0044-8486(03)00127-3

Sundström, G., Dreborg, S., and Larhammar, D. (2010). Concomitant duplications of opioid peptide and receptor genes before the origin of jawed vertebrates. PLoS One 5:e10512. doi: 10.1371/journal.pone.0010512

Suzuki, M. R., and Kikuyama, S. (1983). Corticoids augment nuclear binding capacity for triiodothyronine in bullfrog tadpole tail fins. Gen. Comp. Endocrinol. 52, 272-278. doi: 10.1016/0016-6480(83)90122-3

Sweeting, R. M., Alexander, G. P., Eales, J. G., and McKeown, B. A. (1994). Hepatic and branchial thyroid hormone deiodinase activities associated with the parrsmolt transformation of coho salmon (Oncorhynchus kisutch). Gen. Comp. Endocrinol. 94, 171-181. doi: 10.1006/gcen.1994.1073

Székely, D., Cogǎlniceanu, D., Székely, P., Armijos-Ojeda, D., Espinosa-Mogrovejo, V., and Denoël, M. (2020). How to recover from a bad start: size at metamorphosis affects growth and survival in a tropical amphibian. BMC Ecol. 20:24. doi: 10.1186/s12898-020-00291-w

Tagawa, M., Miwa, S., Inuii, Y., de Jesus, E., and Hirano, T. (1990). Changes in thyroid hormone concentrations during early development and metamorphosis of the flounder, Paralichthys olivaceus. Zool. Sci. 7, 93-96.

Taillebois, L., Keith, P., Valade, P., Torres, P., Baloche, S., Dufour, S., et al. (2011). Involvement of thyroid hormones in the control of larval metamorphosis in (Teleostei: Gobioidei) at the time of river recruitment. Gen. Comp. Endocrinol. 173, 281-288. doi: 10.1016/j.ygcen.2011.06.008

Takeuchi, S., and Takahashi, S. (1998). Melanocortin receptor genes in the chickentissue distributions. Gen. Comp. Endocrinol. 112, 220-231. doi: 10.1006/gcen. 1998.7167

Tanabe, Y. (1982). Ontogenetic aspect of steroidogenesis by gonads and adrenals of ducks and its role on sex differentiation. J. Yamashina Inst. Ornithol. 14, 151-156. doi: 10.3312/jyio1952.14.151

Tanabe, Y., Saito, N., and Nakamura, T. (1986). Ontogenetic steroidogenesis by testes, ovary, and adrenals of embryonic and postembryonic chickens (Gallus domesticus). Gen. Comp. Endocrinol. 63, 456-463. doi: 10.1016/0016-6480(86) 90146-2

Tanabe, Y., Yano, T., and Nakamura, T. (1983). Steroid hormone synthesis and secretion by testes, ovary, and adrenals of embryonic and postembryonic ducks. Gen. Comp. Endocrinol. 49, 144-153. doi: 10.1016/0016-6480(83)90018-7

Tanangonan, J. B., Tagawa, M., Tanaka, M., and Hirano, T. (1989). Changes in tissue thyroxine level of metamorphosing japanese flounder Paralichthys olivaceus reared at different temperatures. Nippon Suisan Gakkai. 55, 485-490. doi: 10.2331/suisan. 55.485

Telemeco, R. S., and Addis, E. A. (2014). Temperature has species-specific effects on corticosterone in alligator lizards. Gen. Comp. Endocrinol. 206, 184-192. doi: 10.1016/j.ygcen.2014.07.004

Thambirajah, A. A., Koide, E. M., Imbery, J. J., and Helbing, C. C. (2019). Contaminant and environmental influences on thyroid hormone action in amphibian metamorphosis. Front. Endocrinol. (Lausanne) 10:276. doi: 10.3389/ fendo.2019.00276

Thompson, C., Weinberger, C., Lebo, R., and Evans, R. (1987). Identification of a novel thyroid hormone receptor expressed in the mammalian central nervous system. Science 237, 1610-1614. doi: 10.1126/science.3629259

Tipsmark, C. K., Jørgensen, C., Brande-Lavridsen, N., Engelund, M., Olesen, J. H., and Madsen, S. S. (2009). Effects of cortisol, growth hormone and prolactin on gill claudin expression in Atlantic salmon. Gen. Comp. Endocrinol. 163, 270-277. doi: 10.1016/j.ygcen.2009.04.020

Tona, K., Onagbesan, O., Bruggeman, V., De Smit, L., Figueiredo, D., and Decuypere, E. (2007). Non-ventilation during early incubation in combination with dexamethasone administration during late incubation: 1. Effects on physiological hormone levels, incubation duration and hatching events. Domest. Anim. Endocrinol. 33, 32-46. doi: 10.1016/j.domaniend.2006.04.002

Trahair, J. F., Perry, R. A., and Robinson, P. M. (1987a). Studies on the maturation of the small intestine in the fetal sheep. I. The effects of bilateral adrenalectomy. Q. J. Exp. Physiol. 72, 61-69.

Trahair, J. F., Perry, R. A., Silver, M., and Robinson, P. (1987b). Studies on the maturation of the small intestine in the fetal sheep. II. The effects of exogenous cortisol. Q. J. Exp. Physiol. 72, 71-79. doi: 10.1113/expphysiol.1987.sp003056

Trahair, J., and Sangild, P. (1997). Systemic and luminal influences on the perinatal development of the gut. Equine Vet. J. 29, 40-50.

Trudeau, V. L., Thomson, P., Zhang, W. S., Reynaud, S., Navarro-Martin, L., and Langlois, V. S. (2020). Agrochemicals disrupt multiple endocrine axes in amphibians. Mol. Cell. Endocrinol. 513:110861. doi: 10.1016/j.mce.2020. 110861

Tseng, C., and Johnson, L. (1986). Role of thyroxine in functional gastric development. Am. J. Physiol. 251, G111-G116.

Ura, K., Hara, A., and Yamauchi, K. (1994). Serum thyroid hormone, guanine and protein profiles during smoltification and after thyroxine treatment in the masu salmon, Oncorhynchus masou. Comp. Biochem. Physiol. Part A Physiol. 107, 607-612. doi: 10.1016/0300-9629(94)90359-X

Usal, M., Veyrenc, S., Darracq-Ghitalla-Ciock, M., Regnault, C., Sroda, S., Fini, J. B., et al. (2021). Transgenerational metabolic disorders and reproduction defects induced by benzo[a]pyrene in Xenopus tropicalis. Environ. Pollut. 269:116109. doi: 10.1016/j.envpol.2020.116109

Vale, W., Spiess, J., Rivier, C., and Rivier, J. (1981). Characterization of a 41residue ovine hypothalamic peptide that stimulates secretion of corticotropin and $\beta$-endorphin. Science 213, 1394-1397. doi: 10.1097/00006254-19820500000013

Van Herck, S. L. J., Delbaere, J., Bourgeois, N. M. A., McAllan, B. M., Richardson, S. J., and Darras, V. M. (2015). Expression of thyroid hormone transporters and deiodinases at the brain barriers in the embryonic chicken: insights into the regulation of thyroid hormone availability during neurodevelopment. Gen. Comp. Endocrinol. 214, 30-39. doi: 10.1016/j.ygcen.2015. 02.021

Van Rensburg, S. J. (1967). Gestation in sheep after foetal adrenalectomy and cortisol acetate administration. J. Endocrinol. 38, 83-84.

Van Tuyl, M., Blommaart, P. E., De Boer, P. A. J., Wert, S. E., Ruijter, J. M., Islam, S., et al. (2004). Prenatal exposure to thyroid hormone is necessary for normal postnatal development of murine heart and lungs. Dev. Biol. 272, 104-117. doi: 10.1016/j.ydbio.2004.03.042

Vargas-Chacoff, L., Dann, F., Paschke, K., Oyarzún-Salazar, R., Nualart, D., Martínez, D., et al. (2021). Freshening effect on the osmotic response of the Antarctic spiny plunderfish Harpagifer antarcticus. J. Fish. Biol. 98, 1558-1571. doi: $10.1111 /$ jfb. 14676

Västermark, A, and Schiöth, H. B. (2011). The early origin of melanocortin receptors, agouti-related peptide, agouti signalling peptide, and melanocortin receptor-accessory proteins, with emphasis on pufferfishes, elephant shark, lampreys, and amphioxus. Eur. J. Pharmacol 660, 61-69. doi: 10.1016/j.ejphar. 2010.10.106 
Veillette, P. A., and Young, G. (2005). Tissue culture of sockeye salmon intestine: functional response of $\mathrm{Na}+-\mathrm{K}+-\mathrm{ATP}$ ase to cortisol. Am. J. Physiol. Regul. Integr. Comp. Physiol. 288, 1598-1605. doi: 10.1152/ajpregu.00741.2004

Verma, G., Khan, M. F., Akhtar, W., Alam, M. M., Akhter, M., and Shaquiquzzaman, M. (2018). Molecular interactions of bisphenols and analogs with glucocorticoid biosynthetic pathway enzymes: an in silico approach. Toxicol. Mech. Methods 28, 45-54. doi: 10.1080/15376516.2017.1356415

Vijayan, M., and Leatherland, J. (1989). Cortisol-induced changes in plasma glucose, protein, and thyroid hormone levels, and liver glycogen content of coho salmon (Oncorhynchus kisutch Walbaum). Can. J. Zool. 67, 2746-2750.

Virtanen, E., and Soivio, A. (1985). The patterns of T3, T4, cortisol and Na+K+ATPase during smoltification of hatchery-reared Salmo salar and comparison with wild smolts. Aquaculture 45, 97-109. doi: 10.1016/0044-8486(85)90261-3

Výboh, P., Zeman, M., Juráni, M., Buyse, J., and Decuypere, E. (1996). Plasma thyroid hormone and growth hormone patterns in precocial Japanese quail and altricial European starlings during postnatal development. Comp. Biochem. Physiol. C Pharmacol. Toxicol. Endocrinol. 114, 23-27. doi: 10.1016/07428413(95)02106-X

Wada, H. (2008). Glucocorticoids: Mediators of vertebrate ontogenetic transitions. Gen. Comp. Endocrinol. 156, 441-453. doi: 10.1016/j.ygcen.2008.02.004

Walpita, C. N., Van der Geyten, S., Rurangwa, E., and Darras, V. M. (2007). The effect of 3,5,3'-triiodothyronine supplementation on zebrafish (Danio rerio) embryonic development and expression of iodothyronine deiodinases and thyroid hormone receptors. Gen. Comp. Endocrinol. 152, 206-214.

Wang, J., Li, J., Zhang, X., and Sun, X. (2012). Transcriptome analysis reveals the time of the fourth round of genome duplication in common carp (Cyprinus carpio). BMC Genomics 13:96. doi: 10.1186/1471-2164-13-96

Warburton, D., Parton, L., Buckley, S., Cosico, L., Enns, G., and Saluna, T. (1988). Combined effects of corticosteroid, thyroid hormones, and ( $\beta$-agonist on surfactant, pulmonary mechanics, and $\beta$-receptor binding in fetal lamb lung. Pediatr. Res. 24, 166-170. doi: 10.1203/00006450-198808000-00005

Weber, B. M., Bowers, E. K., Terrell, K. A., Falcone, J. F., Thompson, C. F., and Sakaluk, S. K. (2018). Pre- and postnatal effects of experimentally manipulated maternal corticosterone on growth, stress reactivity and survival of nestling house wrens. Funct. Ecol. 32, 1995-2007. doi: 10.1111/1365-2435.13126

Weinberger, C., Thompson, C. C., Ong, E. S., Lebo, R., Gruol, D. J., and Evans, R. M. (1986). The c-erb-A gene encodes a thyroid hormone receptor. Nature 324, 641-646. doi: 10.1038/324641a0

Weiss, S. L., Johnston, G., and Moore, M. C. (2007). Corticosterone stimulates hatching of late-term tree lizard embryos. Comp. Biochem. Physiol. A Mol. Integr. Physiol. 146, 360-365. doi: 10.1016/j.cbpa.2006.11.009

Weitzel, J. M., Viergutz, T., Albrecht, D., Bruckmaier, R., Schmicke, M., Tuchscherer, A., et al. (2017). Hepatic thyroid signaling of heat-stressed late pregnant and early lactating cows. J. Endocrinol. 234, 129-141. doi: 10.1530/ JOE-17-0066

Wen, L., He, C., Sifuentes, C. J., and Denver, R. J. (2019). Thyroid hormone receptor alpha is required for thyroid hormone-dependent neural cell proliferation during tadpole metamorphosis. Front. Endocrinol. (Lausanne) 10:396. doi: 10. 3389/fendo. 2019.00396

Wentworth, B. C., and Hussein, M. O. (1985). Serum corticosterone levels in embryos, newly hatched, and young turkey poults. Poult. Sci. 64, 2195-2201. doi: $10.3382 /$ ps.0642195

Williams, G. (2011). Extrathyroidal expression of TSH receptor. Ann. Endocrinol. $72,68-73$.

Wilson, J., Berntsen, H. F., Zimmer, K. E., Verhaegen, S., Frizzell, C., Ropstad, E., et al. (2016). Do persistent organic pollutants interact with the stress response? Individual compounds, and their mixtures, interaction with the glucocorticoid receptor. Toxicol. Lett. 241, 121-132. doi: 10.1016/j.toxlet.2015.11.014

Wise, P. M., and Frye, B. E. (1973). Functional development of the hypothalamohypophyseal-adrenal cortex axis in the chick embryo, Gallus domesticus. J. Exp. Zool. 185, 277-291. doi: 10.1002/jez.1401850302
Yamada, T., Donai, H., Okauchi, M., Tagawa, M., and Araki, K. (2011). Induction of ambicoloration by exogenous cortisol during metamorphosis of spotted halibut Verasper variegatus. Comp. Biochem. Physiol. B Biochem. Mol. Biol. 160, 174-180. doi: 10.1016/j.cbpb.2011.08.004

Yamano, K., and Inui, Y. (1995). cDNA cloning of thyroid hormone receptor beta for the Japanese flounder. Gen. Comp. Endocrinol. 99, 197-203.

Yamano, K., and Miwa, S. (1998). Differential gene expression of thyroid hormone receptor $\alpha$ and $\beta$ in fish development. Gen. Comp. Endocrinol. 109, 75-85. doi: 10.1006/gcen.1997.7011

Yamano, K., Arakai, K., Sekikawa, K., and Inui, Y. (1994). Cloning of thyroid hormone receptor genes expressed in metamorphosing flounder. Dev. Genet. 15, 378-382.

Yaoita, Y., and Brown, D. D. (1990). A correlation of thyroid hormone receptor gene expression with amphibian metamorphosis. Genes Dev. 4, 1917-1924. doi: 10.1101/gad.4.11.1917

Yaoita, Y., Shi, Y.-B., and Brown, D. D. (1990). Xenopus laevis $\alpha$ and $\beta$ thyroid hormone receptors. Proc. Natl. Acad. Sci. U.S.A. 87, 7090-7094.

Yoon, B. H., Romero, R., Jun, J. K., Maymon, E., Mazor, M., and Park, J. S. (1998). An increase in fetal plasma cortisol but not dehydroepiandrosterone sulfate is followed by the onset of preterm labor in patients with preterm premature rupture of the membranes. Am. J. Obstet. Gynecol. 179, 1107-1114.

Yoshimura, T. (2013). Thyroid hormone and seasonal regulation of reproduction. Front. Neuroendocrinol. 34:157-166. doi: 10.1016/j.yfrne.2013.04.002

Young, G. (1986). Cortisol secretion in vitro by the interrenal of coho salmon (Oncorhynchus kisutch) during smoltification relationship with plasma thyroxine and plasma cortisol. Gen. Comp. Endocrinol. 63, 191-200. doi: 10. 1016/0016-6480(86)90156-5

Young, G., Björnsson, B., Prunet, P., Lin, R., and Bern, H. (1989). Smoltification and seawater adaptation in coho salmon (Oncorhynchus kisutch): plasma prolactin, growth hormone, thyroid hormones, and cortisol. Gen. Comp. Endocrinol. 74, 335-345.

Zena, L. A., Dillon, D., Hunt, K. E., Navas, C. A., Buck, C. L., and Bícego, K. C. (2020). Hormonal correlates of the annual cycle of activity and body temperature in the South-American tegu lizard (Salvator merianae). Gen. Comp. Endocrinol. 285:113295. doi: 10.1016/j.ygcen.2019. 113295

Zimmer, C., Boogert, N. J., and Spencer, K. A. (2013). Developmental programming: cumulative effects of increased pre-hatching corticosterone levels and post-hatching unpredictable food availability on physiology and behaviour in adulthood. Horm. Behav. 64, 494-500. doi: 10.1016/j.yhbeh.2013. 07.002

Zoeller, R. T., Tan, S. W., and Tyl, R. W. (2007). General background on the hypothalamic-pituitary-thyroid (HPT) axis. Crit. Rev. Toxicol. 37, 11-53. doi: $10.1080 / 10408440601123446$

Conflict of Interest: The authors declare that the research was conducted in the absence of any commercial or financial relationships that could be construed as a potential conflict of interest.

Publisher's Note: All claims expressed in this article are solely those of the authors and do not necessarily represent those of their affiliated organizations, or those of the publisher, the editors and the reviewers. Any product that may be evaluated in this article, or claim that may be made by its manufacturer, is not guaranteed or endorsed by the publisher.

Copyright (c) 2021 Rousseau, Dufour and Sachs. This is an open-access article distributed under the terms of the Creative Commons Attribution License (CC BY). The use, distribution or reproduction in other forums is permitted, provided the original author(s) and the copyright owner(s) are credited and that the original publication in this journal is cited, in accordance with accepted academic practice. No use, distribution or reproduction is permitted which does not comply with these terms. 